\title{
Expedition 322 summary $^{\mathbf{1}}$
}

Michael B. Underwood, Saneatsu Saito, Yu'suke Kubo, and the Expedition 322 Scientists ${ }^{2}$

\section{Chapter contents}

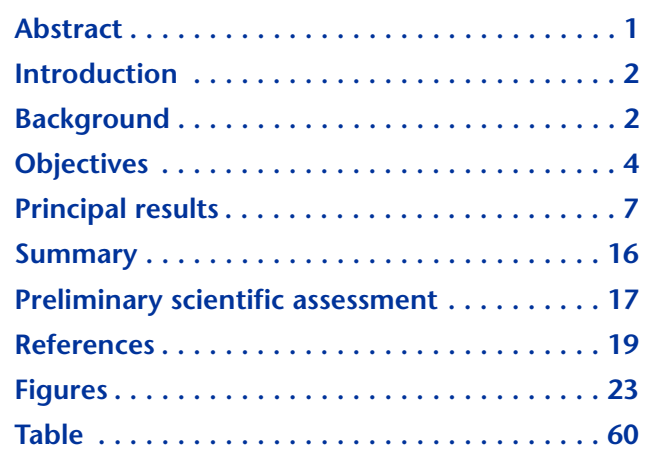

1 Underwood, M.B., Saito, S., Kubo, Y., and the Expedition 322 Scientists, 2010. Expedition 322 summary. In Saito, S., Underwood, M.B., Kubo, Y., and the Expedition 322 Scientists, Proc. IODP, 322: Tokyo (Integrated Ocean Drilling Program Management International, Inc.).

doi:10.2204/iodp.proc.322.101.2010

'Expedition 322 Scientists' addresses.

\section{Abstract}

Integrated Ocean Drilling Program (IODP) Expedition 322 is part of the Nankai Trough Seismogenic Zone Experiment (NanTroSEIZE) and was designed to document characteristics of incoming sedimentary strata and upper igneous basement prior to their arrival at the subduction front. To accomplish these objectives, coring was conducted at two sites in the Shikoku Basin on the subducting Philippine Sea plate. Site C0011 is located on the northwest flank of a prominent bathymetric high (the Kashinosaki Knoll), whereas Site C0012 is located near the crest of the knoll. The resulting data, which include logging while drilling during IODP Expedition 319, provide a wealth of new information on presubduction equivalents of the seismogenic zone. Unfortunately, coring at Site C0011 began at $340 \mathrm{~m}$ core depth below seafloor (CSF) and failed to reach the total depth target because of premature destruction of the drill bit at $876 \mathrm{~m}$ CSF. Coring at Site C0012, however, penetrated almost $38 \mathrm{~m}$ into igneous basement and recovered the sediment/basalt interface intact at $537.81 \mathrm{~m}$ CSF. The age of basal sediment (reddish brown pelagic claystone) is $>18.9 \mathrm{Ma}$. This recovery of basement was a major achievement, as was the comprehensive integration of core-logseismic data at Site C0011. The correlation of lithofacies and agedepth models from the two sites within the Shikoku Basin shows changes from an expanded section (Site C0011) to a condensed section (Site C0012) and captures all of the important ingredients of basin evolution, including a previously unrecognized interval of late Miocene tuffaceous and volcaniclastic sandstone designated the middle Shikoku Basin facies. An older (early to middle Miocene) turbidite sandstone/siltstone facies with mixed detrital provenance occurs in the lower Shikoku Basin; this unit may be broadly correlative with superficially similar Miocene turbidites on the western side of the basin. When viewed together, the two sites around the Kashinosaki Knoll not only demonstrate how basement relief influenced rates of hemipelagic and turbidite sedimentation in the Shikoku Basin, but also build the complete lithostratigraphic template on which all of the postexpedition laboratory results can be placed. Those forthcoming details will include mineral and volcanic ash composition, geotechnical properties, frictional properties, and hydrological properties. Another triumph came from geochemical analyses of interstitial water and hydrocarbons at Site C0012. Unlike other so-called reference sites in the Nankai Trough, interstitial water on top of the 
basement high is largely unchanged by the effects of focused bedding-parallel flow and/or in situ reactions associated with rapid burial beneath the trench wedge and frontal accretionary prism. Thus, Site C0012 finally provides a reliable geochemical reference site for the subduction zone. In addition, geochemical evidence points to the presence of a seawater-like fluid within the upper basaltic crust, which is actively exchanging with the ocean and altering the interstitial water composition of the deep sediments by diffusional exchange.

\section{Introduction}

Integrated Ocean Drilling Program (IODP) Expedition 322 represents just one part of a multistage project known as the Nankai Trough Seismogenic Zone Experiment (NanTroSEIZE). The fundamental goal of NanTroSEIZE is to create a distributed observatory spanning the updip limit of seismogenic and tsunamigenic behavior along a subduction boundary, positioned at a location where great earthquakes are known to occur (Tobin and Kinoshita, 2006a, 2006b). Once completed, the network of boreholes and observatories will allow scientists to monitor the hydrogeologic and geodetic behavior of subduction megathrusts, as well as the aseismic-seismic transition of the megathrust system. To accomplish this ambitious goal, several key components of the plateboundary system must be investigated starting with the presubduction inputs of sediment and oceanic basement, moving landward into the shallow plate interface, and finally drilling to depths where earthquakes occur.

The Nankai Trough region of southeast Japan is among the most extensively studied subduction zones in the world (Fig. F1). The region has a nicely documented $1300 \mathrm{y}$ history of great earthquakes, many of which have generated tsunamis. Recent events of this type include the 1944 Tonankai M 8.2 and 1946 Nankaido M 8.3 earthquakes (Ando, 1975; Hori et al., 2004; Ichinose et al., 2003; Baba and Cummins, 2005). The results of land-based geodetic studies indicate that the plate boundary fault is currently locked (Miyazaki and Heki, 2001). The relatively low level of microseismicity near the updip limits of the 1944 and 1946 great earthquakes (Obana et al., 2004) is consistent with the notion of significant interseismic strain accumulation on the megathrust. Very low frequency earthquake swarms have also been recorded recently, and their apparent locations are within the accretionary prism near the NanTroSEIZE drilling area (Obara and Ito, 2005; Ito and Obara, 2006). This seismic activity demonstrates that interseismic strain is not confined to slow elastic strain accumulation.
Given the backdrop of diverse seismic activity summarized above, our transect across the Kumano Basin region of the Nankai Trough (Fig. F2) was chosen among several candidates to implement NanTroSEIZE. The site selection was based on satisfying three generic criteria:

1. The updip end of the seismogenic zone is definable based on slip during great earthquakes of the recent past.

2. Seismic imaging presents clear drilling targets.

3. Deep targets are within the operational limits of riser drilling by $\mathrm{D} / \mathrm{V}$ Chikyu (i.e., maximum of $2500 \mathrm{~m}$ water depth and $7000 \mathrm{~m}$ subseafloor penetration).

According to studies of slip inversion, past coseismic ruptures within the transect area clearly extended to depths shallow enough for drilling (Tanioka and Satake, 2001; Ichinose et al., 2003; Baba and Cummins, 2005). Coseismic slip during the 1944 Tonankai earthquake may have occurred on the megasplay fault rather than on the décollement beneath it, but both faults represent primary drilling targets of equal importance (Tobin and Kinoshita, 2006a).

\section{Background}

The entirety of the NanTroSEIZE science plan entails seismic reflection, sampling, logging, downhole measurements, and long-term instrumentation of three geologic domains: (1) inputs to the subduction "conveyor belt," (2) faults that splay from the plate interface to the surface and accommodate a major portion of coseismic and tsunamigenic slip, and (3) the main plate interface at $6-7 \mathrm{~km}$ below seafloor. The project has progressed into Stage 2 while following a research strategy that integrates rock mechanics, seismology, geodesy, frictional physics, and fluidfault interactions to shed light on the mechanics and dynamics of faulting processes. Despite recent advances, there is neither a unified theory of fault slip to account for earthquake nucleation and propagation nor is there a theory to explain the mechanisms of strain across the spectrum of observed deformation rates ranging from seconds to years. Consequently, the simple question of whether or not precursor signals exist for major earthquakes, even in theory, remains under scientific debate.

Progress on these topics in earthquake science is limited by a lack of information on ambient conditions and mechanical properties of active faults at depth. Extant rheological models for how faults behave require choices to be made for specific physical properties at the fault interface and in the surrounding rock volume. Coefficients of friction, permeability, pore fluid pressure, state of stress, and elastic stiffness are 
examples of such parameters that can be measured best (or only) through drilling and geophysical sensing of the surrounding rock volume. Conditions for stable versus unstable sliding (i.e., seismic versus aseismic behavior) have long been debated. The frictional strength of likely fault zone materials is another topic of great interest. Fault zone composition, consolidation state, normal stress magnitude, pore fluid pressure, and strain rate may all affect the transition from aseismic to seismic slip (e.g., Moore and Saffer, 2001; Saffer and Marone, 2003). To tease apart the contributions of each, the NanTroSEIZE project was designed to (1) sample fault rocks over a range of pressure-temperature (P-T) conditions across the aseismic-seismogenic transition; (2) document the composition of fault rocks and fluids, as well as associated pore pressure and state of stress; and (3) address spatial partitioning of strain between the décollement and splay faults. NanTroSEIZE will also install borehole observatories to provide in situ monitoring of these critical parameters (seismicity, strain, tilt, pressure, and temperature) over time and test whether or not interseismic variations or detectable precursory phenomena exist prior to great subduction earthquakes.

The overarching hypotheses to be tested by the project are as follows:

1. Systematic, progressive material and state changes control the onset of seismogenic behavior on subduction thrusts.

2. Physical properties, chemistry, and state of the fault zone change systematically with time throughout the earthquake cycle.

3. Subduction zone megathrusts are weak faults.

4. Within the seismogenic zone, relative plate motion is primarily accommodated by coseismic frictional slip in a concentrated zone.

5. The megasplay (out-of-sequence thrust) thrust fault system slips in discrete events, which may include tsunamigenic slip during great earthquakes.

In order to test the first two hypotheses, initial conditions along the subduction conveyor must be established in comprehensive detail and with clarity. We achieved this goal by sampling the incoming sedimentary strata and the top of igneous basement prior to subduction. It is only through such sampling that we can pinpoint how various properties (e.g., clay composition, fluid production, and pore pressure) change in space and time. This relatively simple combination of observational data and laboratory measurements represents the fundamental contribution of Expedition 322 toward the overall success of NanTroSEIZE.

\section{Geological setting}

The purpose of Expedition 322 is to document the characteristics of incoming sedimentary strata and upper igneous basement prior to their arrival at the subduction front of the Nankai Trough. The Shikoku Basin, in which the subducting sediments accumulated, formed during the early and middle Miocene epochs by seafloor spreading along the backarc side of the Izu-Bonin volcanic chain (Okino et al., 1994; Kobayashi et al., 1995). The subducting Philippine Sea plate is currently moving toward the northwest beneath the Eurasian plate at a rate of $\sim 4 \mathrm{~cm} / \mathrm{y}$ (Seno et al., 1993), roughly orthogonal to the axis of the Nankai Trough. Deposits within the Shikoku Basin and the overlying Quaternary trench wedge are actively accreting at the deformation front, as demonstrated by IODP Expeditions 314, 315, and 316 (Stage 1) in the Kumano transect area (Tobin et al., 2009).

As summarized by Underwood (2007), our knowledge of inputs to the Nankai subduction zone is rooted in previous discoveries from numerous boreholes that were drilled along the Muroto and Ashizuri transects (Deep Sea Drilling Project [DSDP] Legs 31 and 87 and Ocean Drilling Program [ODP] Legs 131, 190, and 196) (Karig, Ingle, et al., 1975; Kagami, Karig, Coulbourn, et al., 1986; Taira, Hill, Firth, et al., 1991; Moore, Taira, Klaus, et al., 2001; Mikada, Becker, Moore, Klaus, et al., 2002). Those studies demonstrated, among other things, that the plate boundary fault (décollement) propagates through Miocene strata of the lower Shikoku Basin facies, at least near the toe of the accretionary prism (Taira et al., 1992; Moore et al., 2001). Along the Kumano transect (Fig. F2), seismic reflection data show that the décollement is hosted by lower Shikoku Basin strata to a distance of at least 25-35 km landward of the trench (Fig. F3). Farther landward, the plate boundary fault steps downsection to a position at or near the interface between sedimentary rock and igneous basement (Park et al., 2002). Thus, if the project's goal is to track physical/chemical changes down the plate interface from shallow depths toward seismogenic depths, then the relevant targets for sampling prior to subduction lie within the lower Shikoku Basin.

Regional-scale analyses of seismic reflection data from the Shikoku Basin reveal a large amount of complexity and variability in terms of acoustic character and stratigraphic thickness (Ike et al., 2008a, 2008b). Previous drilling also demonstrated that seafloor relief (created during construction of the underlying igneous basement) strongly influenced the basin's early depositional history (Moore et al., 2001; Underwood, 2007). As an example of such influence, 
a prominent basement high marks the axis of a fossil (middle Miocene) backarc spreading center; the younger Kinan seamount chain is superimposed on the fabric of the extinct ridge (Kobayashi et al., 1995). Evidently, elevation of the seafloor along the seamount chain inhibited transport and deposition of sand by gravity flows. As a consequence, MiocenePliocene sediments above the Kinan Ridge consist almost entirely of hemipelagic mudstone, whereas coeval Miocene strata on the flanks of the Kinan basement high consist largely of sand-rich turbidites (Moore et al., 2001). There are also important differences along strike in heat flow, clay mineral assemblages, and the progress of clay-mineral diagenesis (Underwood, 2007; Saffer et al., 2008). To learn more about how basement might have exerted control over stratigraphic architecture elsewhere in the Shikoku Basin, Expedition 322 was designed to drill two reference sites: one at the crest of a bathymetric high (Kashinosaki Knoll) and the other along the northwest flank of the knoll (Fig. F4).

\section{Site survey data}

In addition to data from previous drilling transects, site survey data near the two proposed sites include multiple generations of two-dimensional (2-D) seismic reflection lines (e.g., Park et al., 2002), heat flow (Yamano et al., 2003), side-scan sonar, swath bathymetry, visual observations from submersible and remotely operated vehicle dives (Ashi et al., 2002), and a three-dimensional (3-D) seismic reflection survey (Moore et al., 2007). A smaller 3-D survey was completed in 2006 by the Japan Agency for MarineEarth Science and Technology-Institute for Research on Earth Evolution (JAMSTEC-IFREE) (Park et al., 2008). Prestack depth migration of the mini-3-D data led to refinements of velocity models and revised estimates of sediment thickness and total drilling depths. The project also greatly benefited from the acquisition of logging-while-drilling (LWD) data from Hole C0011A (proposed Site NT1-07A) during the final days of Expedition 319 (Saffer et al., 2009). Among other things, the LWD data allowed for shipboard adjustments to seismic velocity models and more accurate time-depth conversions.

Our expectations regarding the subsurface facies relations across the flank of the seamount were heavily influenced by coring results from ODP Site 1177, where the boundary between upper Shikoku Basin facies and lower Shikoku Basin facies is a distinction between abundant layers of volcanic ash above and monotonous mudstone below (Moore et al., 2001). At Site 1177, the lower Shikoku Basin also contains four discrete packets of sandy turbidites between $\sim 450$ and $750 \mathrm{~m}$ core depth below seafloor (CSF).
Near Site C0011, we see one distinctive interval of discontinuous high-amplitude seismic reflectors from $\sim 350$ to $500 \mathrm{~m}$ seismic depth below seafloor (SSF) (Fig. F4), and that interval probably coincides with a facies that contains abundant sand beds. However, it is interesting to note that this packet of reflectors can be traced up and over the crest of the Kashinosaki Knoll. Deeper in the seismic section the inferred Miocene turbidites of the lower Shikoku Basin thicken and display outstanding acoustic continuity. That seismic interval begins at $\sim 700 \mathrm{~m} \mathrm{SSF}$ and clearly becomes thinner against the basement high toward the southeast (Fig. F4). These two acoustic intervals, with their inferred contents of sandy sediment, should have a significant influence on 3-D changes in hydrogeological, geotechnical, and frictional properties.

\section{Objectives Scientific objectives}

Research themes for Expedition 322 include (1) evolution of a deepwater turbidite depositional system and facies architecture within the Shikoku Basin; (2) heat flow, diagenesis, and fluid chemistry of mixed terrigenous and open-ocean sediments; (3) volcanic ash stratigraphy and provenance; (4) physical and hydrogeological properties of hemipelagic and turbidite sediments; and (5) petrology, alteration, and hydrology of Layer $2 \mathrm{~A}$ of the oceanic crust (basalt). By drilling two sites on the incoming plate (proposed primary Site NT1-07A and proposed contingency Site NT1-01A), we expected to capture most of the fundamental geologic properties that are likely to change downdip along the plate boundary (Underwood, 2007). As the entire NanTroSEIZE science plan moves forward, we will apply our knowledge of the initial presubduction conditions to improve the observational and theoretical context for interpretation of results from forthcoming and progressively deeper coring. A successful coring program during Expedition 322 will segue into a broad range of shore-based studies aimed at evaluating the interwoven factors that collectively lead to transitions from stable sliding to seismogenic behavior (Saito et al., 2009).

\section{Key scientific questions}

\section{How does the physical hydrogeology of Shikoku Basin respond to variations in primary lithologic architecture and basement structure?}

As one moves across the NanTroSEIZE transect area parallel to strike (i.e., away from the northeast flank of the fossil backarc ridge), the bathymetry of the 
Shikoku Basin is punctuated by off-axis volcanic seamounts and remnant fragments of a deformed Zenisu Ridge (Le Pichon et al., 1987; Mazzotti et al., 2002). As expected, acoustic thickness of sediments generally decreases above larger basement highs (Ike et al., 2008a), but the 3-D architecture, mineral composition, detrital source(s), and directions of gravity flow transport of the lower Shikoku Basin are largely unconstrained by seismic data (Ike et al., 2008b). Basement relief probably blocked or deflected flow paths during early stages of basin infilling, but the local responses remain uncertain in detail. Basementinfluenced heterogeneity of lower Shikoku Basin facies, moreover, carries with it implications for abrupt changes in permeability structure (e.g., because of channels and/or stratigraphic pinch-outs), zonation of fluid pressure, and inconsistent progression of early diagenesis. We expected to uncover evidence of such variations both outboard and inboard of the deformation front as NanTroSEIZE advances through Stages 2 and 3.

To characterize the spatial distribution of porosity and permeability accurately, we still need to map the turbidite sand bodies using recently acquired IFREE 3-D seismic data (Park et al., 2008). More importantly, we also need to characterize hydrologic properties of sandy intervals directly using cores and logs. The turbidite sand bodies of the Shikoku Basin almost certainly provide high-permeability conduits for fluid flow right up to the time when chemical cement or authigenic clays occluded the pore space. If uncemented sand beds still exist, focused fluid flow could be occurring today. Updip pinch-outs of sand bodies against basement highs also may have created compartments of excess pore pressure; this is particularly likely if overpressures get translated laterally during rapid burial beneath the trench wedge and/or accretionary prism (e.g., Bredehoeft et al., 1988). To evaluate this possibility quantitatively, our strategy is to compare hydrologic and geotechnical properties laterally between coeval facies units above basement plain and basement high. The upper boundary of the turbidites is also a likely zone of weakness if fluids migrate out of the turbidite section, are unable to drain vertically through the overlying mudstone aquitard, and create an overpressured zone near the lithologic boundary. As subduction progresses, the presence of sand intervals may simultaneously sustain high pore pressures at the top of the sandy turbidites because of translation of pressure along permeable strata (Bredehoeft et al., 1988; Dugan and Flemings, 2000) and allow improved drainage at their downdip edge, leading to significant changes in effective stress and fault strength in three dimensions (e.g., Saffer and Bekins, 2006).

\section{How do fluids in the igneous basement affect subduction processes?}

We know from studies of ridge-flank environments elsewhere that seawater transport and chemical reactions in upper oceanic basement are complicated (e.g., Fisher, 1998; Wheat et al., 2003). On the other hand, the physical, thermal, and chemical characteristics of fluids in the upper igneous crust of the Shikoku Basin remain almost completely unconstrained by direct sampling. The only constraints come from fluid chemistry just above basement (Moore, Taira, Klaus, et al., 2001). During NanTroSEIZE, we must document how basement fluids evolve chemically and physically in the downdip direction and determine if or how potentially "exotic" fluids migrate vertically or updip from the basement. Additionally, if heat transfer from the basement is affected by hydrothermal circulation (Spinelli and Wang, 2008), then we need to quantify those effects on temperature gradients and rock properties at greater depths. Similarly, it is theoretically possible for fluids derived from or modified by basement sources to be focused along fault zones. To adequately characterize the basalt's physical properties and fluid chemistry prior to subduction, reference holes must penetrate deeper into basement (i.e., 100-200 m below the sediment/basalt interface). As a longer term NanTroSEIZE goal, the plans also include sampling basement fluids in sealed boreholes as a component of observatory installations.

\section{How have system-wide patterns of sediment dispersal affected composition within the Shikoku Basin, particularly on the northeast side of the fossil spreading ridge?}

Diagenesis and porosity reduction in sandstone depend heavily on the initial texture and mineral composition of the sand. The provenance of Miocene turbidites on the northeast side of the Shikoku Basin remains uncertain and must be compared with the basin's southwest side (i.e., offshore Ashizuri and Muroto Peninsulas; Fig. F1). Currently, we know little about clay mineralogy, volcanic ash petrology, or ash alteration on the northeast side of the Shikoku Basin. Preliminary data from Expeditions 315 and 316 (Ashi et al., 2009; Screaton et al., 2009) reveal temporal trends in clay content that are consistent with the Pliocene-Pleistocene sections from offshore of Cape Muroto and Cape Ashizuri (e.g., Underwood and Steurer, 2003; Underwood and Fergusson, 2005), but the older Miocene strata remained largely unsampled prior to Expedition 322. The clay-mineral budget is integral to several important hydration and dehydration reactions (e.g., smectite-illite transition) (Saffer et al., 2008; Saffer and McKiernan, 2009). An 
abundance of clay-size particles also lowers the coefficient of internal friction regardless of mineral type (e.g., Brown et al., 2003). One prediction to test is the enrichment of both detrital and authigenic smectite (an unusually weak expandable clay) in response to larger amounts of volcanogenic input from the Izu-Bonin arc and a weaker northeast-directed proto-Kuroshio Current during the Miocene (Underwood and Steurer, 2003; Underwood and Fergusson, 2005). Temporal changes in ocean circulation and climate also need to be evaluated in concert with constraints on the timing of eruptive activity in nearby volcanic arc systems (e.g., Taylor, 1992; Cambray et al., 1995; Kimura et al., 2005). This spatial-temporal view is important because the waxing and waning of eruptive activity may have triggered widespread changes in both sediment composition and sediment supply rates to different parts of the Shikoku Basin at different times.

\section{How do thermal structure and primary sediment/rock composition modulate diagenesis and fluid-rock interactions prior to subduction?}

Thermal structure, including the effects of fluid circulation in the basement, is a critical input variable to document because of its influence on sediment diagenesis and fluid chemistry (Spinelli and Underwood, 2005; Saffer and McKiernan, 2009). The age of subducting lithosphere within the Kumano transect area is $\sim 20$ Ma (Okino et al., 1994). Heat flow generally decreases with age and distance from the Kinan Seamounts (Wang et al., 1995; Yamano et al., 2003), but we still need to verify this first-order regional pattern with high-quality borehole temperature measurements. The timing of volcanic activity responsible for the birth of Kashinosaki Knoll (Ike et al., 2008a) also needs to be established by dating the basalt.

As subduction carries Shikoku Basin strata toward and beneath the accretionary prism, we expect fluids and physical properties to change downsection and downdip in response to hydration reactions (e.g., volcanic glass to zeolite + smectite), dehydration reactions (e.g., opal-to-quartz and smectite-to-illite), and crystalline cement precipitation (carbonates, zeolites, and silica). Sharp diagenetic fronts (especially opal-to-quartz) have been linked to anomalous offsets in profiles of porosity, $P$-wave velocity, and other geotechnical properties (Spinelli et al., 2007). Dispersed volcanic glass is also potentially important during diagenesis but, as yet, this component of the sediment budget is poorly understood (Scudder et al., 2009). Similarly, hydrous authigenic phases in the basalt (e.g., saponite from ridge-flank hydrothermal alteration) are susceptible to diagenetic reactions at higher temperatures. Updip migration of fluids (including hydrocarbons) toward the Shikoku Basin from landward zones of deeper seated dehydration reactions is a distinct possibility (Saffer et al., 2008), and this idea will be tested through a comprehensive program of geochemical analyses.

\section{Which factor(s) control(s) the décollement's position near the prism toe and at greater depths, together with the fault's mechanical behavior throughout?}

The stratigraphy of fault zones can be dictated by a specific stratigraphic interval with low intrinsic strength, perhaps caused by unusually high contents of clay-size particles and/or smectite-rich clay (e.g., Vrolijk, 1990; Deng and Underwood, 2001; Kopf and Brown, 2003). Another generic possibility is a reduction of effective stress because of excess pore pressure. Causes of excess pore pressure are as diverse as rapid updip migration of pore fluids from deepseated sources, in situ mineral dehydration within poorly drained mudstone, or compaction disequilibrium caused by rapid loading of an impermeable mudstone beneath the landward-thickening trench wedge (e.g., Swarbrick and Osborne, 1998). Pinchouts of highly permeable sand against mudstone aquitards, particularly if combined with compaction disequilibrium and pressure-driven fluid flow, could lead to a complicated 3-D geometry of stratigraphically controlled compartments of excess pore pressure. Strata near the basalt/sediment interface, moreover, may contain abundant smectite. If true, those rocks probably occupy the deeper and more landward zones of preferential weakness where the décollement ramps down (Fig. F3). Permeable sand-rich turbidites may also exert a primary control on décollement strength and downstepping via their effect on pore pressure and thus effective stress (Saffer and Bekins, 2006). Other possibilities to consider include changes in the hydrologic properties of basal sedimentary rock and/or the upper igneous crust (i.e., heterogeneities in permeability might localize overpressures) and changes in rock fabric as a function of protolith (i.e., the uneven development of slaty or phyllitic fabric may respond to inherited variations in sediment texture, composition, and earlier diageneticmetamorphic history).

Seamount subduction also affects the structure of the frontal accretionary prism (Yamazaki and Okamura, 1989). Evidence from the frontal Kumano transect suggests widespread perturbation of structural architecture due to a subducting seamount just to the southwest of the 3-D seismic coverage (Moore et al., 2009). Among the adjustments to subducting base- 
ment highs are the décollement ramping up to the seafloor and oblique thrust development (Screaton et al., 2009). These large-scale tectonic overprints may overwhelm the influences of such inherited compositional factors as cementation or clay mineralogy. Our challenge now is to discriminate between the presubduction factors inherited from Shikoku Basin (documented during this expedition) and the changes imparted by increasing P-T conditions and stress changes at depth (documented in the future by deep riser drilling).

\section{Drilling plan}

To reiterate, the primary plan for Expedition 322 was to sample within the Shikoku Basin and quantify initial conditions in the materials that are tectonically delivered to the subduction system. Geologic materials within the lower half of the Shikoku Basin are what ultimately enter the seismogenic zone and host slip along the deep megasplay and the deep décollement. Preexisting relief on the Shikoku Basin igneous crust obviously affected the spatial distribution of various sediment types and sedimentation rates, so our original plan (Saito et al., 2009) was to drill two sites: a condensed section on a basement high (proposed contingency Site NT1-01 [Hole C0012A]), and a thicker sand-rich section off that high (proposed primary Site NT1-07 [Hole C0011B]). A full program of coring and wireline logging of the sedimentary section was planned for Site C0011, and we benefited greatly from early acquisition of LWD data from Hole C0011A during the final days of Expedition 319. Log-seismic integration after the acquisition of LWD data indicated a depth to basement of $\sim 1050 \mathrm{~m}$ SSF. Another change in plan came as a result of premature bit destruction and failure to reach the total depth (TD) target during coring in Hole C0011B. A quick assessment of the time remaining led to our decision to move to the contingency site (Hole C0012A). The coring summary is shown in Table T1.

\section{Principal results Site C0011}

\section{Core-Log-Seismic integration}

Near the end of Expedition 319, measurement-whiledrilling (MWD) and LWD data were collected in Hole C0011A. Although the time allocation for this operation was not long enough to reach basement, acquisition of these data proved to be extremely beneficial. MWD data include rate of penetration (ROP), rotational speed, and stick-slip. LWD data (acquired using Schlumberger geoVISION tool) include natural gamma radiation, five different resistivity readings, and resistivity images from button resistivity measurements. Generally, the data quality is good, and we were able to make confident correlations between the logs and subsequent core description and multisensor core logger (MSCL) data, with a vertical offset of $\sim 4 \mathrm{~m}$ between the coring hole and the logging hole. LWD data were divided into five logging units on the basis of visual inspection of the gamma ray and ring resistivity responses (Fig. F5). These divisions also correlate reasonably well with the seismic stratigraphy (Fig. F6). The log characteristics attributed to several secondary lithologies can be discriminated from a dominant background lithology interpreted to be hemipelagic mud(stone).

Logging Unit 1 (0-251.5 m LWD depth below seafloor [LSF]) exhibits minor fluctuations in gamma ray and a very gradual decrease in ring resistivity. These attributes are consistent with a lithology of hemipelagic mud (silty clay to clayey silt). Logging Unit 2 (251.5-478.5 m LSF) corresponds to a series of high-amplitude seismic reflections, which are laterally variable and discontinuous. The logging Unit $1 / 2$ boundary is marked by steplike offsets of both gamma ray and resistivity values. The most striking features within logging Unit 2 are the high resistivity spikes, which coincide with low gamma ray peaks. The blocky log signature of this unit is indicative of local sand-filled submarine channels (Fig. F7), and the higher resistivity values may be due to a high concentration of volcanic glass shards within the sand-size fraction (see "Lithology"). Logging Unit 3 (478.5-736.0 m LSF) exhibits increases in both the gamma ray trendline and ring resistivity, with little variation. At $\sim 650 \mathrm{~m} \mathrm{LSF}$, the log character changes to include low gamma ray peaks and low ring resistivity spikes (Subunit 3C), which we interpret to be intervals of terrigenous sandstone. Logging Unit 4 (736.0-867.0 m LSF) exhibits a series of four inferred fining- and coarsening-upward sequences that correlate with a series of high-amplitude seismic reflections with excellent lateral continuity. We interpret these intervals as packets of sand-rich turbidites. Logging Unit 5 (867.0-950.5 m LSF) is characterized by a sharp increase in the ring resistivity log, followed by minor fluctuations around a constant trendline. Gamma radiation decreases slightly with depth. Our interpretation of this unit is heavily consolidated hemipelagic mudstone.

Structural analysis of the borehole resistivity images shows that the majority of bedding dips are inclined $<20^{\circ}$ toward the north, which is consistent with the gentle dip observed in the seismic profiles down the seaward slope of the trench (Fig. F3). Analysis of borehole breakouts indicates that the maximum horizontal 
stress field $\left(S_{\mathrm{Hmax}}\right)$ is orientated north-northeastsouth-southwest, roughly perpendicular to the convergence direction of the Philippine Sea plate.

\section{Lithology}

Because of the time constraints imposed by 11.5 days of operational time set aside for contingencies (e.g., typhoon evacuation), coring at Site C0011 (Hole C0011B) began at $340 \mathrm{~m}$ CSF rather than the mudline (Fig. F8). For the most part, core recovery was modest to poor. We identified five lithologic units in Hole C0011B (Fig. F9). Because Unit I was not cored, its character is inferred based on LWD data and analogy with the upper part of the Shikoku Basin at several other drilling sites (ODP Sites 808, 1173, 1174, and 1177). The dominant lithology of the upper Shikoku Basin facies is hemipelagic mud (silty clay to clayey silt) with thin interbeds of volcanic ash. Discrimination among all of the other lithologic units was based on a combination of visual core description (VCD), smear slide petrography, bulk powder Xray diffraction (XRD), and X-ray fluorescence (XRF).

Lithologic Unit II is late Miocene ( 7.6 to $9.1 \mathrm{Ma})$ in age and extends from 340.0 to $479.06 \mathrm{~m}$ CSF. Because of its unique combination of detrital composition and age, we have designated this unit as the middle Shikoku Basin facies (Fig. F8). The upper part (340-377 m CSF) consists of moderately lithified bioturbated silty claystone with interbeds of tuffaceous sandstone, whereas the lower part (377-479 m CSF) contains bioturbated silty claystone, volcaniclastic sandstone, and dark gray siltstone without appreciable bioturbation. The distinction between tuffaceous and volcaniclastic sandstone is based on the abundance of pumice and volcanic glass shards (Fig. F10). Unit II also contains a chaotic interval of intermixed volcaniclastic sandstone and bioturbated silty claystone (mass transport deposit). Bulk powder XRD data show scattering within Unit II as a function of grain size; sandy specimens are enriched in feldspar, whereas hemipelagic mudstones contain higher percentages of total clay minerals (Fig. F11). Bulk powder XRF data show an intriguing gradient of $\mathrm{Al}_{2} \mathrm{O}_{3}$ and an abrupt shift to higher $\mathrm{Al}_{2} \mathrm{O}_{3}$ below $377 \mathrm{~m} \mathrm{CSF}$ (Fig. F12). This shift in bulk geochemistry may have been caused by a change in the clay-mineral assemblage. Judging from smear slide petrography, we suggest that the volcanic-rich sands were derived from an active volcanic arc as a mixture of primary eruptive products and reworking of pyroclastic and sedimentary deposits. The closest volcanic source at the time was probably located along the northeast margin of the Shikoku Basin (Izu-Bonin arc), but shorebased analyses of the volcaniclastic grains will be needed to pinpoint the detrital provenance. Channel- like sand-body geometry is evident in both LWD data (Fig. F7) and seismic character, and transport/ deposition probably occurred in the distal part of a submarine channel system.

Lithologic Unit III is middle-late Miocene ( 9.1 to $\sim 12.2 \mathrm{Ma}$ ) in age and extends from 479.06 to $673.98 \mathrm{~m}$ CSF. The dominant lithology is bioturbated silty claystone, typical of the hemipelagic deposits in the Shikoku Basin. Secondary lithologies include sporadic dark gray silty claystone, lime mudstone, and very thin beds of ochre-colored calcareous claystone. The unit's boundaries are defined at the top by a thin bed of cemented terrigenous sandstone and at the bottom by the appearance of dark gray clayey siltstone (mud turbidites). The most interesting aspect of this unit is a change in the rate of hemipelagic sedimentation at $\sim 11 \mathrm{Ma}$ (Fig. F13), which is evident from both biostratigraphic and paleomagnetic data uncorrected for compaction (see "Biostratigraphy" and "Paleomagnetism"). Bulk powder XRD and XRF data show monotonous compositions within Unit III, punctuated by scattered layers of carbonate-rich mudstone (Figs. F11, F12).

Lithologic Unit IV is middle Miocene ( 12.2 to $\sim 14.0 \mathrm{Ma})$ in age and extends from 673.98 to $849.95 \mathrm{~m}$ CSF. Core recovery within this interval was particularly poor, and our interpretations were further hampered by poor core quality and the decision to wash down without coring from 782.6 to $844.0 \mathrm{~m}$ CSF. The dominant lithology of Unit IV is bioturbated silty claystone with abundant interbeds of dark gray clayey siltstone (deposited by muddy turbidity currents) and fine-grained siliciclastic sandstone (deposited by sandy turbidity currents). The sandstone beds are $10-80 \mathrm{~cm}$ thick and typically display plane-parallel laminae. Small wood fragments are common, as are detrital grains of polycrystalline quartz and metamorphic rock fragments. We interpret the terrigenous source of this sandy detritus to be somewhere along the Outer Zone of southwest Japan, where such tectonostratigraphic units as the Sanbagawa metamorphic belt and the Shimanto Belt crop out across the strike length of the Kii Peninsula, Shikoku, and Kyushu (e.g., Taira et al., 1989; Nakajima, 1997). Superficially similar sand deposits with overlapping ages have been documented on the west side of the Shikoku Basin at Site 1177 and DSDP Site 297 offshore the Ashizuri Peninsula of Shikoku (Marsaglia et al., 1992; Fergusson, 2003; Underwood and Fergusson, 2005).

The age of lithologic Unit $\mathrm{V}$ is poorly constrained within the middle Miocene ( 14.0 Ma). The unit extends from 849.95 to 876.05 m CSF, but our ability to characterize these strata was also hampered by poor core recovery. The unit's upper boundary is de- 
fined by the first occurrence of tuff, and the lower boundary coincides with the destruction of the drill bit, which led to cessation of coring. The dominant lithologies are tuffaceous silty claystone and light gray tuff with minor occurrences of tuffaceous sandy siltstone (Fig. F14). XRD data show an abundance of smectite and zeolites (undifferentiated clinoptilolite/ heulandite and analcime) within this unit as alteration products of volcanic glass. The tuffs are probably correlative with the thick rhyolitic tuffs that were recovered at Site 808 from the Muroto transect of the Nankai Trough, which yielded an age of $\sim 13.6 \mathrm{Ma}$ (Taira, Hill, Firth, et al., 1991).

\section{Structural geology}

More than 300 individual structural features were described and measured in the cores from Hole C0011B. Whenever possible, these features were reoriented to a geographic coordinate system using shipboard paleomagnetic data. Most of the features are characterized by subhorizontal to gently dipping bed planes and small faults (Fig. F15). Synsedimentary creep structures and layer-parallel faults (referred to as deformation bands at Sites 1174 and 808) developed in lithologic Units II and III, whereas a high-angle normal fault/fracture system exhibiting brittle features is pervasive in lithologic Units IV and V. Deformation-fluid interactions were also deduced from mineral-filled veins precipitated along faults in the lowermost part. Although the numbers of paleomagnetic correction are limited, attitudes of these structures seem to be controlled by bathymetry; poles to these structures are distributed along a north-northwest-south-southeast trend, perpendicular to the present trench axis. The structural distributions in cores correlate nicely with the logging-based measurements of planar orientations (Fig. F5).

\section{Biostratigraphy}

Preliminary analysis of samples from Hole C0011B revealed assemblages of calcareous nannofossils and planktonic foraminifers. Biostratigraphic datums are taken mainly from coccoliths. According to these datum events, the composite sequence for Hole C0011B ranges from middle to upper Miocene, roughly equivalent to $13.65 \mathrm{Ma}$ at the lowest datum up to $8.52 \mathrm{Ma}$ at $425 \mathrm{~m} \mathrm{CSF}$ (Fig. F9).

\section{Paleomagnetism}

Because of the failure of the cryogenic magnetometer (superconducting quantum interference device), paleomagnetic studies for Hole C0011B consisted of natural remanent magnetization (NRM) measurements and alternating-field (AF) and thermal demagnetizations on discrete samples. We noted that tuffaceous and volcaniclastic sandstones within lithologic Unit II display NRM intensity peaks. There is a broad NRM intensity high from 530 to $570 \mathrm{~m} \mathrm{CSF}$ that appears to correspond to changes in $P$-wave velocity and sedimentation rate at $\sim 11 \mathrm{Ma}$. Changes in magnetic susceptibility are largely consistent with the variations in NRM intensity. Both responses are probably caused by fluctuations in the type and/or abundance of magnetic minerals. Several relatively well defined polarity intervals were identified in downhole magnetostratigraphic records, and these reversals were correlated with the geomagnetic polarity reversal timescale.

\section{Integrated age-depth model}

Using biostratigraphic data, we were able to correlate certain parts of the magnetic polarity interval with the geomagnetic polarity reversal timescale and create an integrated age-depth model (Fig. F16). Overall, the paleomagnetic data indicate ages ranging from $\sim 7.6$ to $\sim 14.1 \mathrm{Ma}$. The composite age-depth model yields sedimentation rates (uncorrected for either compaction or rapid event deposition by gravity flows) ranging from $\sim 4.0 \mathrm{~cm} / \mathrm{k} . \mathrm{y}$. in the upper part of Unit III to $9.5 \mathrm{~cm} / \mathrm{k} . \mathrm{y}$. in the lower part of lithologic Units III and IV (Fig. F16). The average rate calculated for lithologic Unit II is $9.4 \mathrm{~cm} / \mathrm{k} . \mathrm{y}$. The sedimentation rate within Unit III changed at 11 Ma. Magnetostratigraphic records also suggest the existence of a geomagnetic excursion or short reversed polarity event within lithologic Unit V. This anomalous paleomagnetic inclination, however, falls within an interval of soft-sediment folding in tuffaceous material.

\section{Physical properties}

Physical property measurements at Site C0011 provide indications of bulk formation properties, which we were able to correlate with lithologic variation and compare with profiles from other drill sites in the Shikoku Basin. For example, sharp increases in magnetic susceptibility (from the MSCL) correlate nicely with individual sandstone beds in lithologic Unit II (Fig. F17). In addition, a shift in magnetic susceptibility in Unit III near 575 m CSF correlates with a change in sedimentation rate at $\sim 11$ Ma (Fig. F16). Calculated values of bulk density and porosity show a downhole increase in bulk density (1.5$\left.2.1 \mathrm{~g} / \mathrm{cm}^{3}\right)$ and decrease in porosity $(0.55-0.32)$, indicative of sediment consolidation (Fig. F18). These trends correlate with increases in compressional velocity $\left(V_{\mathrm{P}}\right)$ and electrical resistivity. The velocityporosity relation is consistent with previous observations from Shikoku Basin sediments (Hoffman and Tobin, 2004). Although the trend for $V_{\mathrm{P}}$ increases 
downhole, this increase is subdued from $575 \mathrm{~m} \mathrm{CSF}$ to the base of Unit III, thereby correlating with the change in magnetic susceptibility mentioned above. Velocity anisotropy changes from isotropic to anisotropic (i.e., horizontal velocity faster than vertical velocity) near $440 \mathrm{~m} \mathrm{CSF}$ (Fig. F19), and we attribute this change to compaction-induced alignment of mineral grains. Thermal conductivity varies between 0.98 and $1.77 \mathrm{~W} /(\mathrm{m} \cdot \mathrm{K})$ in mudstone and between 1.11 and $1.75 \mathrm{~W} /(\mathrm{m} \cdot \mathrm{K})$ in sandstone.

Although crude first-order trends are clear in the profiles, drilling and coring disturbance perturbed the results of bulk physical property measurements in several important ways. To begin with, decreased core diameter from rotary core barrel (RCB) coring resulted in whole-round multisensor core logger (MSCL-W) calculated values that are not representative of in situ conditions; these volume-related artifacts can be remedied through advanced processing involving integration of X-ray computed tomography data. Another likely source of error is inaccurate grain density measurements, as those values also show an unusually high range of scatter. A more serious problem is that many cores were damaged by microscale cracks and fractures induced by drilling, coring, and/or the recovery processes, particularly during periods of high heave and drill bit deterioration. Our sampling procedure tried to avoid regions that had visible fractures; however, the data show evidence of pervasive internal disturbance. This disturbance is most obvious in the unusually high variability in bulk density and porosity values and in $P$-wave velocity measured on cube samples (Figs. F18, F19). The observed trend of thermal conductivity, which decreases as porosity decreases, is counterintuitive and also confirms the existence of small water-filled fractures, leading to measured values that are lower than in situ values.

\section{Downhole measurements}

Because of time constraints and the omission of hydraulic piston coring system coring, we failed to make any temperature measurements during Expedition 322. The sediment temperature-pressure (SET-P) tool was successfully tested in the drill string above the seafloor. Prior to deployment, the SET-P tool was connected to the colleted delivery system (CDS) and placed into the RCB bottom-hole assembly (BHA) to ensure that the landing mechanism engaged correctly. The test consisted of lowering the SET-P tool downhole with stops at 988 and $1989 \mathrm{~m}$ below sea level for reference measurements. Measured pressure data confirmed hydrostatic pressure within the drill string, and the temperature data correctly recorded temperature variation. Based on the observations, the test deployment was successful. The SET-P tool was not deployed in the formation, however, because of ambiguity in correlating LWD data with MSCL-W data, the sporadic presence of hard layers, and the lack of sand(stone) recovery in previous cores. This combination of factors led to large uncertainties in the location and in situ properties of our primary targets (thick sand beds), which elevated the risk of deployment to unacceptable levels.

\section{Inorganic geochemistry}

The inorganic geochemistry objectives at this site were partially achieved by collecting 46 whole-round samples for interstitial water analysis. Routine sampling density was one per core, but collection of good-quality samples was difficult throughout the hole because of extreme core disturbance and low water content of the formation. Contamination by seawater is evident in all data profiles, and corrections were made on the basis of sulfate concentrations.

The top of the sampled sediment section (340 m CSF) lies beneath the sulfate/methane interface; thus, we do not have information on shallow processes associated with organic carbon diagenesis. Chlorinity in the sampled fluids decreases from $\sim 550 \mathrm{mM}$ to $\sim 7 \%$ less than seawater (Fig. F20). This freshening trend is superficially consistent with the trend observed at Site 1177, which was drilled seaward of the deformation front in the Ashizuri transect during Leg 190 (Moore, Taira, Klaus, et al., 2001). Judging from the similarity of the two chlorinity profiles, we suggest that the sampled fluids may have originated from greater depth by clay dehydration reactions. If this is true, then fluid migration toward Site C0011 probably occurred updip along permeable conduits of turbidite sandstone. Unfortunately, recovery of the sandstone was insufficient to characterize their hydrogeologic properties and vertical extent. The lack of reliable temperature constraints also hinders a more definitive interpretation of the chlorinity data (i.e., in situ dehydration versus deeper seated dehydration). The distributions of major and minor cations document extensive alteration of volcanogenic sediments and oceanic basement, including the formation of zeolites and smectite-group clay minerals. These reactions lead to consumption of silica, potassium, and magnesium and production of calcium (Fig. F20). The very high calcium concentrations $(>50 \mathrm{mM})$ favor authigenic carbonate formation, even at alkalinity of $<2 \mathrm{mM}$. Those results are consistent with the recovery of scattered lenses/beds of lime-rich mudstone (Fig. F11).

\section{Organic geochemistry}

Concentrations of nitrogen and sulfur are low in all lithologic units. Organic carbon, total sulfur, and to- 
tal nitrogen contents are, on average, equal to $0.31 \pm$ $0.17 \mathrm{wt} \%, 0.37 \pm 1.47 \mathrm{wt} \%$ and $0.06 \pm 0.02 \mathrm{wt} \%$, respectively. Organic carbon contents show more scatter in lithologic Unit II than in Unit III (Fig. F21). $\mathrm{C} / \mathrm{N}$ ratios of $\sim 6.0 \pm 3.1$ indicate a marine origin of the sedimentary organic matter, but two elevated values in Units II and IV suggest increased input from terrigenous sources. In general, inorganic carbon contents $(0.4 \pm 0.9 \mathrm{wt} \%)$ are only slightly larger than organic carbon contents and correspond to a mean calcium carbonate content of $2.3 \mathrm{wt} \%$. Elevated carbonate contents up to $62 \mathrm{wt} \%$ coincide with thin beds of lime-rich mudstone.

In spite of the sediment's low organic carbon content, dissolved hydrocarbon gas concentrations in the interstitial water increase with depth. Methane is present as a dissolved phase in all samples (Fig. F22). Ethane was detected in all but one core taken from depths $>422 \mathrm{~m}$ CSF. Dissolved propane was first observed at $568 \mathrm{~m} \mathrm{CSF}$ and is present in almost all deeper cores. Butane occurs sporadically deeper than $678 \mathrm{~m}$ CSF. The occurrence of ethane below $422 \mathrm{~m}$ CSF results in low $\mathrm{C}_{1} / \mathrm{C}_{2}$ ratios $\sim 280 \pm 80$ (Fig. F22). The low $\mathrm{C}_{1} / \mathrm{C}_{2}$ ratios are unusual for sediments with organic carbon contents of $<0.5 \mathrm{wt} \%$. Without better constraints on temperature at depth, these results are difficult to interpret with confidence. In situ production of heavier hydrocarbons is possible, but that would require burial temperatures warmer than predicted by the erratic values of near-surface heat flow near the Kashinosaki Knoll (Yamano et al., 2003). In addition, unlike the monotonic increases in headspace gas concentrations with depth at Site 1173 (Moore, Taira, Klaus, et al., 2001), the dissolved hydrocarbon concentrations increase within lithologic Units III and IV but then decrease within lithologic Unit V (Fig. F22). One explanation for this pattern is hydrocarbon generation within a deeper/hotter source and migration along sandy intervals of higher permeability.

\section{Microbiology}

The microbiology component of Site C0011 was limited to whole-round sampling for molecular (phylogenetic) studies, fluorescence in situ hybridization (FISH), and cell counting studies. Interstitial water samples were also obtained for shipboard spectrophotometric analyses of ferrous iron and acid volatile sulfide and measured using a third-party tool.

\section{Site $\mathrm{C0012}$}

\section{Lithology}

At Site C0012, we identified six sedimentary lithologic units on the basis of sediment composition, sediment texture, and sedimentary structures (Fig. F23). Unit VII is composed of basalt (igneous basement). For the most part, core recovery was modest to poor (Fig. F24) and damage to the core was typically severe. Nevertheless, several correlations of distinctive marker beds were made between this site and Site C0011, and we recognized several lithologic units common to both sites.

Lithologic Unit I was not cored between 0.81 and $60 \mathrm{~m}$ CSF. It is $150.86 \mathrm{~m}$ thick and extends from the seafloor to $150.86 \mathrm{~m}$ CSF, below which we observed the first occurrence of volcaniclastic sandstone. The age of this interval ranges from Quarternary to late Miocene (0 to $\sim 7.8 \mathrm{Ma}$ ). The dominant lithology is green-gray intensely bioturbated silty clay, typical of hemipelagic mud deposits. Thin layers of volcanic ash are scattered throughout. The results of bulk powder XRD show modest amounts of calcite within this unit, consistently above trace quantities (Fig. F25). This retention of biogenic carbonate is compatible with deposition on top of the Kashinosaki Knoll at a water depth close to (but above) the calcite compensation depth. This lithologic unit is correlative with logging Unit 1 at Site C0011.

Lithologic Unit II is late Miocene ( 7.8 to $\sim 9.4 \mathrm{Ma})$ in age. We applied the designation of middle Shikoku Basin facies because of this unit's unique composition (i.e., volcanic rather than siliciclastic sand) and age relative to broadly equivalent Miocene turbidites cored along the Ashizuri transect. This unit is $68.95 \mathrm{~m}$ thick and extends from 150.86 to $219.81 \mathrm{~m}$ CSF. Stratigraphic equivalents to the facies at Site C0011 are present here as very coarse to finegrained tuffaceous to volcaniclastic sandstone. The dominant lithology is green-gray silty claystone, alternating with medium- to thick-bedded tuffaceous/ volcaniclastic sandstone and dark gray clayey siltstone. Lithologic Unit II contains two chaotic deposits that are 0.3 and $3.1 \mathrm{~m}$ thick (150.86-151.17 and 178.00-181.10 m CSF, respectively). As also observed at Site C0011, these deposits consist of disaggregated pieces of volcanic-rich sandstone and bioturbated silty claystone with folding, thinning, and attenuation of primary bedding, probably deformed by gravitational sliding on the relatively steep north-facing slopes of the Kashinosaki Knoll. XRD data show scatter in concentrations of total clay minerals and feldspar because of lithologic heterogeneity (Fig. F25). The closest source of volcaniclastic sand at the time was probably the Izu-Bonin volcanic arc (Taylor, 1992). Unlike the flank setting of Site C0011, however, deposition of sand on top of the knoll must have required upslope transfer by turbidity currents (e.g., Muck and Underwood, 1990) and/or postdepositional uplift of the basement high. 
Lithologic Unit III is middle Miocene ( 9.4 to $\sim 12.7 \mathrm{Ma}$ ) in age. It is $112.0 \mathrm{~m}$ thick and extends from 219.81 to $331.81 \mathrm{~m} \mathrm{CSF}$. The interval is characterized by bioturbated silty claystone, typical of hemipelagic deposition. With the exception of scattered carbonate beds and bentonites, the homogeneity of this unit results in very consistent XRD-deduced mineral abundances and major oxides (Figs. F25, F26). Unit III also contains an interval at least $15.2 \mathrm{~m}$ thick with steeply inclined bedding, typically at an angle of $40^{\circ}-45^{\circ}$ (see "Structural geology"). From seismic evidence, this disruption appears to be associated with rotational normal faulting. Biostratigraphic data also yield evidence of a possible hiatus near the top of this interval.

Lithologic Unit IV is middle Miocene ( $>12.7$ to $13.5 \mathrm{Ma}$ ) in age. It is $86.48 \mathrm{~m}$ thick and extends from 331.81 to $415.58 \mathrm{~m}$ CSF. This interval is characterized by alternations of silty claystone, thin clayey siltstone, and normally graded siltstone. We interpret the siltstone beds to have resulted from turbidity currents. This unit shows a trend of increasing $\mathrm{Fe}_{2} \mathrm{O}_{3}$ and decreasing $\mathrm{Na}_{2} \mathrm{O}$ with depth (Fig. F26), and XRD data show some shifts in mineralogy because of grain size effects (Fig. F25).

The age of lithologic Unit $\mathrm{V}$ ranges from early to middle Miocene (13.5 to $\geq 18.9 \mathrm{Ma})$. It is $112.93 \mathrm{~m}$ thick and extends from 415.58 to $528.51 \mathrm{~m}$ CSF. A major unconformity occurs at $\sim 491 \mathrm{~m} \mathrm{CSF}$, with an apparent hiatus of $\sim 4$ m.y. (see "Biostratigraphy"). The Unit IV/V boundary is subtle and defined by an appearance of volcanic tuff. The main lithology in Unit V is silty claystone; coarser interbeds in the lower part of the unit consist of siliciclastic sandstone, volcaniclastic sandstone, and rare tuff. The sandstones, some of which display spectacular crosslaminae, plane-parallel laminae, convolute laminae, and soft-sediment sheath folds (Fig. F27), appear to have two separate detrital provenances judging from point counts of smear slides: (1) a volcanic source with fresh volcanic glass, together with relatively large amounts of feldspar, and (2) a siliciclastic source enriched in sedimentary lithic grains, quartz, and heavy minerals (including pyroxene zircon and amphibole). The Outer Zone of southwest Japan (e.g., Shimanto Belt) is the likely siliciclastic source. Bulk XRD confirms that relative percentages of quartz and feldspar increase significantly in the coarse-grained strata (Fig. F25), and XRF data show appreciable scatter in most of the major oxides because of lithologic/textural heterogeneity (Fig. F26). This range of compositions, textures, and ages is also reminiscent of the older turbidite intervals and volcaniclastic-rich facies at Site 1177 (Moore, Taira, Klaus, et al., 2001).
Lithologic Unit VI is early Miocene in age (>18.9 Ma). It is only $9.3 \mathrm{~m}$ thick and extends from 528.51 to $537.81 \mathrm{~m}$ CSF. This unit is characterized by variegated red, reddish brown, and green calcareous claystone, rich in nannofossils, with minor amounts of radiolarian spines. Carbonate content is $\sim 20 \mathrm{wt} \%$ based on bulk powder XRD analysis (Fig. F25). We interpret this unit as a pelagic clay deposit in direct contact with igneous basement.

\section{Igneous petrology}

Successful recovery of volcanic basement in Hole C0012A defined lithologic Unit VII. On the basis of the nannofossils in overlying red claystone, the volcanic rock is older than $18.921 \mathrm{Ma}$. The cored interval extends from 537.81 to $576 \mathrm{~m} \mathrm{CSF}$, and a sharp contact between red claystone and basalt is beautifully preserved in Core 322-C0012A-53R (Fig. F27). The $38.2 \mathrm{~m}$ of basement coring resulted in $18 \%$ recovery, consisting of (1) pillow lava basalt, (2) basalt, (3) basaltic hyaloclastite breccia, and (4) mixed rubble pieces of basalt caused by drilling disturbance. Basalts and pillow basalts have aphanitic to porphyritic textures. Phenocryst abundance is highly variable, from slightly to highly phyric textures. This variability is not restricted to separate intervals but is also observed across diffuse limits between highly phyric and sparsely phyric basalts. Phenocrysts are composed mostly of plagioclase, pyroxene, and sparse altered olivine. Othopyroxene is dominant compared to clinopyroxene. Pyrite is present as an accessory mineral in some basalts. Vesicularity is highly heterogeneous. In a single sequence, basalts can have sparse $(1 \%-5 \%)$ to high (>20\%) vesicle content. VCD and thin section analyses show evidence of magma mixing.

Alteration ranges from moderate to very high, with a large proportion of basalts being highly altered. Alteration styles include interstitial groundmass replacement, vesicle fill, vein formation (with associated alteration halos), and complete replacement of pillow lava glass rims by alteration materials. Secondary mineralogical phases comprise saponite, celadonite, zeolite, pyrite, iddingsite, quartz, and calcite. Therefore, basalts from Site C0012 exhibit the effects of several stages of alteration from relatively high temperature facies $\left(>200^{\circ} \mathrm{C}\right.$ for zeolite and saponite) to low-temperature facies $\left(<30^{\circ} \mathrm{C}\right.$ for celadonite).

One thin layer of hyaloclastite breccia was recovered, but many fractures are filled with brecciated material. These breccias are composed of clasts that are similar to the surrounding basalts and are sealed with celadonite and saponite. Given the low recovery of these intervals, it is not possible to determine 
the relation between the hyaloclastite potions and underlying lavas.

\section{Structural geology}

Structures measured in cores from Hole C0012A consist of bedding planes, minor faults, and fractures. The beds usually dip gently to the north; steep bedding dips occur only in lithologic Unit III (Fig. F28). Rotation of bedding to higher angles probably occurred by large block sliding on the north-inclined seafloor of the Kashinosaki Knoll. The sliding apparently resulted in a brief time gap (angular unconformity) as deduced by nannofossil datums (see "Biostratigraphy"). Small high-angle faults and fractures strike north-northwest-south-southeast, and the poles show girdle distribution trending eastnortheast-west-southwest. Because most slickenlines on the fault surfaces exhibit dip-slip movements, the direction of intermediate principal stress apparently trends north-northwest-south-southeast, perpendicular to the trench. Deformation-fluid interactions are also evident from calcite-filled veins precipitated along faults in the lower part of the sedimentary section.

\section{Biostratigraphy}

Preliminary analysis of the core catcher and additional samples from Cores 322-C0012A-1R through 52R reveal assemblages of calcareous nannofossils and planktonic foraminifers. Biostratigraphic datums are recognized mainly from calcareous nannofossils. The oldest depositional age at Site C0012 is early Miocene (18.921-20.393 Ma; that event has a depth range of 528.67-530.32 m CSF). The average calculated sedimentation rate (uncorrected for compaction) changes from $3.27 \mathrm{~cm} / \mathrm{k} . \mathrm{y}$. above $216 \mathrm{~m}$ CSF to $6.93 \mathrm{~cm} / \mathrm{k} . \mathrm{y}$. below $235 \mathrm{~m}$ CSF. That change occurred within lithologic Unit III at $\sim 9.53-10.88 \mathrm{Ma}$, and it may be associated with a brief hiatus in sedimentation (i.e., the angular unconformity described in "Structural geology"). Another likely hiatus exists above the Unit V/VI boundary at $\sim 491 \mathrm{~m} \mathrm{CSF}$, with an age gap from 14.914 to $18.921 \mathrm{Ma}$.

\section{Paleomagnetism}

Magnetic property variations among various lithologies are similar to those observed at Site C0011. For example, the typical silty claystones yield relatively low NRM intensity compared to sandstone and volcaniclastic sandstone. In lithologic Unit III, both NRM intensity and magnetic susceptibility show abrupt downhole decreases. We collected four basalt samples from the basement unit and subjected them to detailed $\mathrm{AF}$ and thermal demagnetization experiments. Shipboard measurements followed by shore-based measurements show negative inclination, indicating that basaltic basement was formed during a reversed polarity chron. Several relatively well-defined polarity intervals were identified in downhole magnetostratigraphic records. Using biostratigraphic data, we were able to correlate patterns of the magnetic polarity interval recorded in the sediments against the standard geomagnetic reversal timescale. In particular, the polarity interval between 7.5 and 8.5 Ma can be correlated with confidence.

\section{Integrated age-depth model}

The integrated age-depth model from biostratigraphy and magnetostratigraphy gives an age of $\sim 7.8 \mathrm{Ma}$ at the Unit I/II boundary (Fig. F29) and indicates a significant increase in sediment accumulation rate across the boundary (from $\sim 2 \mathrm{~cm} / \mathrm{k} . \mathrm{y}$. above to $\sim 6 \mathrm{~cm} / \mathrm{k}$.y. below). The composite model yields an age of $\sim 9.4 \mathrm{Ma}$ at the Unit II/III boundary. The age model for older parts of the sedimentary section is less certain, especially where core recovery was poor. The integrated model indicates an age of $\sim 13.5 \mathrm{Ma}$ for the Unit IV/V boundary (Fig. F29).

\section{Physical properties}

The physical properties of sedimentary strata at Site C0012 are similar to those documented at Sites C0011 and 1177. Profiles show downhole increases in bulk density, electrical resistivity, thermal conductivity, and $P$-wave velocity, together with a downhole decrease in porosity (Fig. F30). These trends are consistent with conditions of normal consolidation. It is important to note, however, that multiple forms of disturbance from drilling and coring processes affected core quality in a negative and widespread way, as did the scatter in grain density values. These artifacts reduced the quality of data and should be considered as additional research progresses, including shore-based geotechnical experiments. Typical symptoms of coring damage include decreased core diameter, microscale water-filled cracks and fractures, and abnormally low thermal conductivity. On the positive side, Hole C0012A did yield a few intervals of good core recovery where data are of high quality. Furthermore, it is possible to recognize and interpret the general depth-dependent trends in physical properties through the cloud of disturbance effects.

Spikes in magnetic susceptibility in lithologic Unit II correlate with sandstone beds. In Unit III, we observe a step decrease in magnetic susceptibility similar to the one at Site C0011, which correlates to a change in sediment accumulation rate. An interval with increasing magnetic susceptibility and decreasing natural gamma radiation from $480 \mathrm{~m} \mathrm{CSF}$ to the base of 
Unit VI correlates with the appearance of sandstone layers containing iron-rich minerals.

The consolidation trend for Site C0012 begins with a single near-seafloor porosity measurement of 0.70 in Core 322-C0012-1R; values decrease to a porosity of 0.35 by $530 \mathrm{~m} \mathrm{CSF}$ (Fig. F30). Compressibility is twice that interpreted for Site C0011. In a manner somewhat similar to what was documented at Sites 1173, 1177, and C0011, Site C0012 displays an anomalous interval in the shallow subsurface (100$136 \mathrm{~m} \mathrm{CSF}$ ) where changes in porosity are subdued (Fig. F30). We identify two additional zones of anomalous porosity: (1) scattered values throughout lithologic Unit III and (2) the top of lithologic Unit V. Intervals and individual specimens with abnormally high porosity indicate lower apparent compressibility, and the changes could be controlled by grain shape, sediment composition, or cement. Higher porosity near the Unit IV/V boundary may facilitate fluid migration at depth.

Increases in $P$-wave velocity downhole are consistent with increases in bulk density and decreases in porosity (Fig. F30). $P$-wave velocity in the sedimentary section ranges from 1600 to $2100 \mathrm{~m} / \mathrm{s}$. Samples from Sites C0011 and C0012 have higher velocity for a given porosity than at Site 1173 . This suggests higher bulk and/or shear moduli of sediments at Sites C0011 and C0012. $P$-wave velocity of basalt ranges from 3000 to $4750 \mathrm{~m} / \mathrm{s}$. Vertical-plane velocity anisotropy is nearly zero in lithologic Unit I but then increases with depth through Unit II into Unit VI. This likely reflects preferential grain orientation and enhanced grain contacts from consolidation. Around $450 \mathrm{~m}$ CSF, a cluster of samples near sandrich layers has negative $V_{\mathrm{P}}$ anisotropy.

Thermal conductivity varies between 0.98 and $1.47 \mathrm{~W} /(\mathrm{m} \cdot \mathrm{K})$ in $\operatorname{mud}($ stone) and between 1.19 and $2.10 \mathrm{~W} /(\mathrm{m} \cdot \mathrm{K})$ in sand(stone). Thermal conductivity increases with depth in lithologic Units I and II; this change is controlled by porosity loss. A step decrease in thermal conductivity in Unit III coincides with a marked decrease in core quality.

\section{Inorganic geochemistry}

A total of 42 pore fluid samples were collected from whole-round sections between 89.4 and $529.5 \mathrm{~m} \mathrm{CSF}$ for chemical and isotopic analyses. Interstitial water volume decreases monotonically with depth, but in contrast to the distribution in Site C0011, there is no correlation between the volume of water and lithologic unit or sand content. Even though the strata here are moderately lithified, the core quality is significantly better than at Site C0011; thus, contamination by drilling fluid was much less severe. The results from Site C0012 come as close as we can get to a true geochemical reference site for the Nankai Trough. There are no obvious effects of abnormally high heat flow (as we see along the Muroto transect) and/or rapid burial beneath the Quaternary trench wedge and accretionary prism toe.

The dissolved sulfate profile for Hole C0012A shows quite a bit of structure (Fig. F31), which is consistent with biogeochemical processes. The values preclude any correction for potential contamination because a total depletion of sulfate in the formation fluids could not be assumed. The sulfate profile clearly documents an abnormal sulfate reduction zone (Fig. F31), which is significantly deeper $(\sim 300 \mathrm{~m} \mathrm{CSF})$ than those detected at other sites along the Nankai margin. At Site 1173, for example, sulfate is undetectable below 6 meters below seafloor (mbsf) (Moore, Taira, Klaus, et al., 2001). The subdued microbial activity in the upper sections of Hole C0012A may be due to lower sedimentation rates above the basement high, as compared to the flanks of the Kashinosaki Knoll, which receive more voluminous supplies of terrigenous organic matter by turbidity currents. Sulfate depletion at $\sim 300 \mathrm{~m}$ CSF also coincides with an increase in dissolved methane and ethane concentrations in the interstitial water (Fig. F32). One explanation for the presence of these hydrocarbons, which occur in significantly lower concentrations here than at Site C0011, is updip migration of gas in solution from deeper thermogenic sources. Another possibility is in situ biogenic formation from terrigenous organic matter. Regardless, it is likely that the sulfate concentrations at Site C0012 are modulated by anaerobic methane oxidation (AMO), thereby leading to the production of hydrogen sulfide. In support of this idea, we observed a marked increase in hydrogen sulfide concentration concomitant with the peak in methane concentration. Among the iron sulfide minerals, pyrite is common in the sediments over a comparable depth range.

Unlike Site C0011, chlorinity values at Site C0012 increase by $12 \%$ relative to seawater. Uniform values of $\sim 560 \mathrm{mM}$ occur within lithologic Units I and II and increase to a maximum of $627 \mathrm{mM}$ at $509 \mathrm{~m} \mathrm{CSF}$ (Fig. F31). This steady increase in chlorinity is probably a response to hydration reactions during alteration of dispersed volcanic ash and volcanic rock fragments (i.e., volcanic glass reacting to smectite and zeolites) within Units IV and V. The profile for Site C0012 is unique with respect to all of the other Shikoku Basin sites; it shows no indication of the freshening patterns observed elsewhere (Taira et al., 1992; Moore et al., 2001). The only other site in the Nankai Trough to show similar increases in chlorinity is Site C0004, which was drilled above the shallow megasplay fault in the accretionary prism (Expedi- 
tion 316 Scientists, 2009). Regardless of the cause, the absence of freshening at Site C0012 indicates a lack of hydrologic connectivity between the flanks (Site C0011) and the crest of the basement high.

Temperature-dependent alteration of volcanic ash and volcaniclastic fragments within the middle range of the sedimentary section (lithologic Units III, $\mathrm{IV}$, and V) probably controls the changes in silica, potassium, and magnesium concentrations (Fig. F31), which almost certainly are in equilibrium with montmorillonite (a common smectite group clay mineral) below $250 \mathrm{~m}$ CSF. Increases in dissolved calcium in Unit II are probably overprinted at greater depths by deep-seated reactions in the basal sediments (pelagic claystone). Dissolved calcium concentrations are even higher than observed at Site $\mathrm{C} 0011$ and help explain the precipitation of $\mathrm{CaCO}_{3}$ (observed as thin layers and nodules), even at very low alkalinity $(<2 \mathrm{mM})$. Depletion of dissolved sodium is probably also due to formation of zeolites (clinoptilolite, heulandite, and analcime) from alteration of dispersed volcanic glass and plagioclase in the basalt.

In addition, the profiles of all major cations and sulfate show an intriguing reversal toward more seawaterlike values within the lower half of lithologic Unit V (Fig. F31). We tentatively attribute this shift to the presence of a seawater-like fluid migrating through the upper basaltic crust and diffusive exchange through the turbidites of lithologic Unit V. The hydrology responsible for this pattern, including potential recharge and discharge zones for fluids within upper igneous basement, remains unidentified.

We need temperature constraints and refined shorebased analyses to interpret the geochemistry with greater confidence, but shipboard results point to the intriguing possibility of two distinct fluid regimes that alter the chemical composition of the interstitial water of the sediments seaward of the trench. One regime is characterized by dehydration reactions together with possible migration through high-permeability horizons of middle and lower Shikoku Basin facies. The geochemical fingerprints for this regime are a combination of fluid freshening and the presence of heavier hydrocarbons. No such freshening is observed at Site C0012. Rather, the only hints of a lateral flow are small concentrations of dissolved methane and ethane. Unlike its flanks, the crest of Kashinosaki Knoll reveals a separate interstitial water regime. Here, the composition of the fluids is driven by in situ hydration reactions and migration of a seawater-like fluid through the upper basaltic crust, which modifies the chemical composition of the overlying sediment section by diffusional exchange. Especially noteworthy is the observed in- crease in sulfate below 490 m CSF, which cannot be supplied by the methane bearing fluids that moved toward the knoll from the deeper landward side. Furthermore, the fact that we see an increase in hydrogen sulfide produced by AMO in the overlying sediments argues for sustained presence of sulfate below $490 \mathrm{~m}$ CSF, which must be supplied by active flow in the highly permeable basalt below.

\section{Organic geochemistry}

At Site C0012, dissolved hydrocarbon gases were not detected in the upper $189 \mathrm{~m}$ of sediment. Levels of dissolved methane are low in all cores below this depth (Fig. F32). Methane concentrations increase to a maximum of $244 \mu \mathrm{M}$ at $417 \mathrm{~m}$ CSF (as compared to a maximum of nearly $8000 \mu \mathrm{M}$ at Site C0011). In the same vicinity, dissolved ethane $\left(\mathrm{C}_{2}\right)$ was detected but reaches a concentration maximum of only $3.9 \mu \mathrm{M}$ at $417 \mathrm{~m}$ CSF before dropping off toward basement. Propane $\left(\mathrm{C}_{3}\right)$ and butane $\left(\mathrm{C}_{4}\right)$ are absent in all cores. The methane and ethane concentration maxima fall within a zone of sporadic increases in total organic carbon content (Fig. F33), but the very low $\mathrm{C}_{1} / \mathrm{C}_{2}$ ratios are unusual for sediments with such generally low contents of organic carbon $(<0.5 \mathrm{wt} \%)$. Potential sources of the higher hydrocarbon gases (i.e., in situ biogenic production versus migration from deeper hotter sources) remain to be explored by additional shore-based investigations.

In general, nitrogen and sulfur contents are low (Fig. F33). Inorganic carbon contents $(0.4 \pm 0.9 \mathrm{wt} \%)$ and organic carbon contents $(0.3 \pm 0.1 \mathrm{wt} \%)$ show sporadic excursions toward higher values in all lithologic units. The corresponding mean calcium carbonate value is $3.26 \mathrm{wt} \%$, but local occurrences of lime mudstone reach $63.6 \mathrm{wt} \%$ (consistent with XRD data). Total sulfur contents are on average $0.24 \mathrm{wt} \%$ but show distinct excursions toward higher values at the Unit IV/V boundary and reach a maximum of $4.3 \mathrm{wt} \%$ in Unit $\mathrm{V}$. $\mathrm{C} / \mathrm{N}$ ratios $\sim 6.7$ indicate a predominantly marine origin of the organic matter, but ratios $>25$ indicate the presence of terrigenous organic matter in Unit V.

The occurrences of higher sulfur contents in the solid phase of sediments from the upper part of Unit $\mathrm{V}$ are $\sim 10 \mathrm{~m}$ deeper than maxima in dissolved methane, ethane, and sulfide concentrations at the lithologic Unit IV/V boundary. This observation gives rise to several questions. Does the presence of terrigenous organic matter in Unit V support the metabolic activity of deeply buried microorganisms, which in turn results in the in situ formation of biogenic methane and ethane, or have thermogenic hydrocarbons migrated from a deeper source? In either case, methane consumption and sulfide formation by 
AMO are possible wherever sulfate and methane are available.

\section{Microbiology}

The microbiology component of Site C0012 was limited to whole-round sampling for molecular (phylogenetic) studies, FISH, and cell counting studies. Interstitial water samples were also obtained for shipboard spectrophotometric analyses of ferrous iron and acid volatile sulfide and measured using a third-party tool.

\section{Logging and core-log-seismic integration}

Wireline logs were not obtained from Hole C0012B because of difficult conditions in the borehole and expiration of time to prepare for a typhoon evacuation. Coring results, however, allowed some refinements in the interpretation of seismic reflection data. Six seismic stratigraphic units were recognized (Fig. F34).

\section{Summary}

Figure F35 shows the provisional correlation of lithologic units between Sites C0011 and C0012. The approximate ages of unit boundaries are also shown, using the respective composite age-depth models for the two sites. In general, there is good agreement between the two data sets. In particular, a close match exists for the lithologic Unit I/II boundary, which marks the base of the upper Shikoku Basin facies. Based on its age and volcaniclastic sand content, Unit II is unique to the Kumano transect area and has been designated herein as the middle Shikoku Basin facies. Equivalent deposits were not cored within either the Muroto or Ashizuri transects, and the closest volcanic source at the time was the IzuBonin arc. The stratigraphic transition into the lower Shikoku Basin seems to correlate with a similar transition to a dominantly hemipelagic lithology at other sites in the Shikoku Basin and accretionary prism toe, but the ages are different. At all other localities across the Nankai margin, what has been classified as the upper part of the lower Shikoku Basin consists of monotonous heavily bioturbated hemipelagic mudstone, ranging in age from $\sim 3.5$ to 6.0 Ma. At Sites C0011 and C0012, the hemipelagic facies occurred earlier in the basin's evolution during the middle-late Miocene ( 9.1 to $\sim 12.7 \mathrm{Ma})$. Below that stratigraphic interval, the sandy turbidite facies of the lower Shikoku Basin seems to match up with broadly coeval packets of siliciclastic turbidite that were recovered at Site 1177 along the Ashizuri transect. Detailed petrographic work will be required to quantify petrofacies, compare the detrital prove- nance, and piece together the regional system of sediment dispersal on both the west and east sides of the basin.

Recovery of basal pelagic deposits in contact with pillow basalt constitutes a major achievement at Site C0012. We know that the age of the basement is older than $\sim 18.9 \mathrm{Ma}$, based on nannofossil assemblages in the overlying pelagic sediment. Radiometric age dating will be needed to establish the eruptive age of the basalt.

When viewed as a pair of stratigraphic columns, it is clear that the condensed section at Site C0012 displays significant reductions in unit thickness for all correlative parts of the two stratigraphic columns, including the sand-rich intervals (Fig. F36). This is another important discovery. Although relief on the bathymetric high may have been enhanced by inversion at some point in the late Miocene or Pliocene, the basement clearly modulated sedimentation rates throughout the history of the Shikoku Basin. Relief on the seafloor, however, was never high enough to completely prevent the transport and deposition of sandy detritus at the crest of the bathymetric high (Kashinosaki Knoll). Deposition of sandy detritus at Site C0012 may have resulted from thick turbidity currents and/or upslope flow of gravity flows.

Although some important coring intervals are missing, the composite stratigraphic succession at Sites C0011 and C0012 (Fig. F36) captures all of the ingredients that we need to complete an assessment of changes in geologic properties down the subduction zone to seismogenic depth. This composite provides the template upon which all of the postexpedition laboratory results will be placed, particularly the details of composition, fluid chemistry, geotechnical properties, frictional properties, and porosity/permeability.

In addition to material properties, profiles of interstitial water geochemistry for Site C0012 represent the closest we have seen to a true geochemical reference site for the Nankai Trough. Unlike Site C0011, where a freshening trend is obvious in the interstitial water, Site C0012 yields no evidence for significant in situ dehydration reactions or movement of freshened fluids updip to the crest of the bathymetric high (Fig. F37). Instead, chlorinity increases toward the basement because of hydration reactions and diffusional exchange with fluids in the underlying basalt. In essence, that site represents the presubduction geochemical reference site for the Nankai subduction zone, with pore fluids unaffected by the effects of focused flow and diagenesis associated with rapid burial beneath the trench wedge and frontal accretionary prism. These geochemical data, together with the precise fingerprints of isotopic analyses, will be crucial for evaluating the evolution of fluid-rock 
interactions from the distal reaches of the Shikoku Basin through the frontal accretion zone, and finally into the seismogenic zone.

\section{Preliminary scientific assessment}

Recovery of core from Site C0012, including successful penetration of igneous basement, was a major achievement for NanTroSEIZE, as was the acquisition of LWD logs from Site C0011 prior to coring. Based on preliminary analysis of the sandstone petrology, we now know that two sand-rich turbidite systems developed within the Shikoku Basin during the middle and late Miocene epochs. The younger system, which is characterized by a volcanic source of detritus, was sampled for the first time during this expedition. Another major success story involves acquisition of reliable interstitial water geochemistry data at Site C0012. But the expedition also suffered several failures and disappointments. Below, we provide candid assessments of each major objective in the science plan.

\section{Objectives}

\section{Objective 1: Core and log the lowermost sedimentary strata of the Shikoku Basin and the top of igneous basement}

When viewed within the context of the entire NanTroSEIZE science plan, this objective was the most important for Expedition 322 to achieve. This high priority is rooted in the fact that lowermost Shikoku Basin strata and uppermost basement host the plate boundary fault and the deep megasplay fault at seismogenic depths. Prior to drilling, the estimated depth to basement at Site C0011 was set at $1050 \mathrm{~m}$ SSF. LWD logging operations in Hole C0011A were terminated short of basement at $950 \mathrm{~m}$ LSF because of time limitations at the end of Expedition 319. Coring operations in Hole C0011B were terminated at $876 \mathrm{~m} \mathrm{CSF}$ after exceedingly slow ROPs, followed by destruction of the drill bit. Consequently, our most important objective remained unfulfilled at the primary site.

Our decision to occupy contingency Site C0012 (proposed Site NT1-01) was driven by the strong desire to achieve Objective 1. Prior to drilling, the estimated depth to sediment/basalt interface at the basement high was placed at $515 \mathrm{~m}$ SSF using refined velocity models and constraints from LWD logs at Site C0011. We did achieve this coring goal, intersecting the top of basement at $537.81 \mathrm{~m} \mathrm{CSF}$ and continuing $\sim 20 \mathrm{~m}$ into basalt. TD for Hole C0012A was $560.74 \mathrm{~m}$ CSF.

Much of the science party's postexpedition research will focus on analyses of samples from the lower stratigraphic units of the Shikoku Basin. Those studies will provide much-needed information about the pristine physical, chemical, compositional, and hydrological properties of the subduction inputs prior to the effects of subduction. On the negative side, attempts to obtain wireline logs at Site C0012 met with failure, which limits our ability to extend core-logseismic integration beyond the immediate vicinity of that borehole.

Objective 2: Core and log the sandy turbidite facies of the lower Shikoku Basin, and assess its potential for focused lateral transport of fluids via geochemical analyses of interstitial water and gases

Cores and LWD logs both show that the Shikoku Basin contains two prominent intervals of sand-rich turbidite deposits. The hydrogeologic objective, however, met with limited success in Hole C0011B because of poor core recovery and an extensive interval of wash down within the inferred turbidites of the lower Shikoku Basin. LWD logs help constrain the 2-D geometry of the turbidite intervals, and core recovery was just enough to characterize the sandstone petrofacies and detrital provenance. The overall hydrogeologic properties and 3-D stratigraphic architecture of the sand bodies remain largely unknown. On the other hand, indirect evidence for focused fluid flow can be extracted from interstitial water geochemistry and hydrocarbon concentrations. Correlative facies were also recovered at Site C0012, which allows us to extend the characterization of fluid composition and fluid transport from the flank of the basement high to the updip extension of correlative facies units. These data point to two separate regimes that modify interstitial water composition of sediments prior to subduction: (1) seawater-like fluid in the upper igneous basement, which modifies interstitial water chemistry by diffusional exchange, and (2) dehydration reactions within a deeper seated sedimentary source coupled with focused flow toward the Shikoku Basin up the flank of the basement high. The presence of these two regimes and the lack of hydrological connectivity between Sites C0011 and C0012 are two of the more significant discoveries of Expedition 322.

\section{Objective 3: Construct detailed profiles} of interstitial water geochemistry within the lowermost sedimentary strata of the Shikoku Basin as an indicator of fluid chemistry within upper basement

We failed to achieve this objective at Site C0011 because of premature termination of the coring hole (destruction of bit). Furthermore, geochemical pro- 
files higher in the sedimentary section are ambiguous with respect to a possible basement fluid source because of the extensive amounts of contamination by drilling fluid. At Site C0012, however, pore fluid samples were successfully extracted from cores in close proximity to the sediment/basement interface. Initial evaluation of the data reveals several intriguing possibilities for fluid sources, migration pathways, and mixing, including a more seawater-like fluid flowing through the upper basement. At this site, chlorinity increases above seawater values by $12 \%$ toward the basement contact, whereas all of the other comparable sites in the Shikoku Basin and trench show freshening of interstitial water with depth. In addition, the sulfate reduction zone is much deeper than anticipated at Site C0012, and sulfate depletion coincides with increases in methane and ethane concentrations. The sulfate profile is probably driven by AMO and hydrogen sulfide production. There is also widespread geochemical evidence for alteration of volcanic material at both sites; this alteration includes a component of dispersed ash, volcanic sand, and the basaltic basement. These hydration reactions result in depletion of silica, potassium, and magnesium, together with high levels of dissolved calcium. As stated above, the interstitial water geochemistry program was a major success when viewed in its entirety.

\section{Objective 4: Measure in situ pore pressure within the turbidite facies of the lower Shikoku Basin}

Deployment of the SET-P tool was aborted in Hole C0011B because of ambiguities in the location and properties of our primary targets for measurement. Although sand beds were clearly defined by LWD data, we did not recover sand(stone) beds immediately above the target interval for probe insertion, which raised the level of risk. Thus, we failed to achieve this objective.

\section{Objective 5: Construct a complete depth profile of sediment physical properties and integrate those changes with trends in sediment composition and texture}

This objective was not achieved at Site C0011 because coring was interrupted by several extensive washdown intervals. We also failed to reach the anticipated TD at Site C0011. In addition, for the core that was recovered, measured values of porosity, $P$ wave velocity, $V_{\mathrm{P}}$ anisotropy, and electrical resistivity were compromised by pervasive damage to the core. Widespread occurrences of water-filled microcracks led to an unfortunate expansion of the scatter and artifacts in all types of physical property data. This noise makes it more difficult to compare results from Expedition 322 with other data sets in the Shikoku Basin and Nankai Trough. The physical property profiles for Site C0012 are more consistent than for Site C0011, but those data also suffer from the effects of widespread coring disturbance and poor recovery. This problem needs to be taken into consideration when attempting to interpret the results of shorebased laboratory tests of consolidation state, permeability, and related properties.

\section{Objective 6: Reconstruct the complete history} of Shikoku Basin sedimentation in the vicinity of the Kashinosaki Knoll, including age, detrital provenance, dispersal paths, contributions of volcaniclastic/pyroclastic versus siliciclastic material, and physical mechanisms of transport and deposition

In spite of the spotty recovery of turbidite sand beds, having core samples from two reference sites in the Shikoku Basin will allow sedimentary petrologists, mineralogists, and geochemists to conduct a comprehensive program of shore-based analyses. The goal will be to determine the composition, age, and provenance of sedimentary sources throughout the last $20 \mathrm{~m} . \mathrm{y}$. of basin evolution. Examination of smear slides during the expedition provided evidence for multiple detrital sources, but quantitative shore-based research will add details through age dating of such grain types as zircon and chemical fingerprinting of single pyroxene grains and volcanic glass shards. Scientists will also analyze dispersed volcanic ash in the hemipelagic mudstone and quantify the composition and alteration state of clay-mineral assemblages. When integrated with the age constraints provided by nannofossils, foraminifers, and paleomagnetic reversals, the compositional data will provide an unprecedented view of the basin's history in the region between the Kinan seamount chain and the Izu-Bonin volcanic arc. Ultimately, we will be able to combine that regional reconstruction with information already available from the Muroto and Ashizuri transect areas to the west, thereby demonstrating how different parts of the backarc basin responded to major tectonic and climate events during the margin's Miocene-Quaternary evolution.

\section{Objective 7: Integrate and correlate among cores, logs, and seismic profiles from the seaward edge of the trench wedge to the crest of the Kashinosaki Knoll}

Overall, the core-log-seismic integration effort was marginally successful. Our ability to extend correlations for significant distances away from the two drill sites was limited by the small size of the mini- 
3-D seismic survey and the proprietary hold on most of the seismic data. Ties between logs and core were hampered by poor recovery and ubiquitous damage to the cores. Pervasive water-filled microcracks led to unreliable measurements of porosity, density, and $P$-wave velocity. The severity of this damage can be seen in the mismatch between reflections on the seismic line through Site C0011 and the synthetic seismogram, which was calculated using the values from discrete measurements of physical properties on core. In addition, the wireline logging program at Site C0011 was cancelled, and logging at Site C0012 failed because of operational difficulties and evacuation from an approaching typhoon. On the positive side, our success in making qualitative comparisons between logging units identified from LWD data and lithologic units identified during VCD improved the interpretations of basin stratigraphy and facies evolution.

\section{References}

Ando, M., 1975. Source mechanisms and tectonic significance of historical earthquakes along the Nankai Trough, Japan. Tectonophysics, 27(2):119-140. doi:10.1016/0040-1951(75)90102-X

Ashi, J., Kuramoto, S., Morita, S., Tsunogai, U., Goto, S., Kojima, S., Okamoto, T., Ishimura, T., Ijiri, A., Toki, T., Kudo, S., Asai, S., and Utsumi, M., 2002. Structure and cold seep of the Nankai accretionary prism off Kumano-outline of the off Kumano survey during YK01-04 Leg 2 cruise. JAMSTEC J. Deep Sea Res., 20:1-8. (in Japanese, with abstract in English)

Ashi, J., Lallemant, S., Masago, H., and the Expedition 315 Scientists, 2009. Expedition 315 summary. In Kinoshita, M., Tobin, H., Ashi, J., Kimura, G., Lallemant, S., Screaton, E.J., Curewitz, D., Masago, H., Moe, K.T., and the Expedition 314/315/316 Scientists, Proc. IODP, 314/ 315/316: Washington, DC (Integrated Ocean Drilling Program Management International, Inc.). doi:10.2204/iodp.proc.314315316.121.2009

Baba, T., and Cummins, P.R., 2005. Contiguous rupture areas of two Nankai Trough earthquakes revealed by high-resolution tsunami waveform inversion. Geophys. Res. Lett., 32(8):L08305. doi:10.1029/2004GL022320

Bredehoeft, J.D., Djevanshir, R.D., and Belitz, K.R., 1988. Lateral fluid flow in a compacting sand-shale sequence: South Caspian Basin. AAPG Bull., 72:416-424.

Brown, K.M., Kopf, A., Underwood, M.B., and Weinberger, J.L., 2003. Compositional and fluid pressure controls on the state of stress on the Nankai subduction thrust: a weak plate boundary. Earth Planet. Sci. Lett., 214(34):589-603. doi:10.1016/S0012-821X(03)00388-1

Cambray, H., Pubellier, M., Jolivet, L., and Pouclet, A., 1995. Volcanic activity recorded in deep-sea sediments and the geodynamic evolution of western Pacific island arcs. In Taylor, B., and Natland, J. (Eds.), Active Margins and Marginal Basins of the Western Pacific. Geophys. Monogr., 88:97-124.

Deng, X., and Underwood, M.B., 2001. Abundance of smectite and the location of a plate-boundary fault, Barbados accretionary prism. Geol. Soc. Am. Bull., 113(4):495-507. doi:10.1130/00167606(2001)113<0495:AOSATL >2.0.CO;2

Dugan, B., and Flemings, P.B., 2000. Overpressure and fluid flow in the New Jersey Continental slope: implications for slope failure and cold seeps. Science, 289(5477):288-291. doi:10.1126/sci-

ence.289.5477.288

Expedition 316 Scientists, 2009. Expedition 316 Site C0004. In Kinoshita, M., Tobin, H., Ashi, J., Kimura, G., Lallemant, S., Screaton, E.J., Curewitz, D., Masago, H., Moe, K.T., and the Expedition 314/315/316 Scientists, Proc. IODP, 314/315/316: Washington, DC (Integrated Ocean Drilling Program Management International, Inc.). doi:10.2204/iodp.proc.314315316.133.2009

Fergusson, C.L., 2003. Provenance of Miocene-Pleistocene turbidite sands and sandstones, Nankai Trough, Ocean Drilling Program Leg 190. In Mikada, H., Moore, G.F., Taira, A., Becker, K., Moore, J.C., and Klaus, A. (Eds.), Proc. ODP, Sci. Results, 190/196: College Station, TX (Ocean Drilling Program), 1-28. doi:10.2973/ odp.proc.sr.190196.205.2003

Fisher, A.T., 1998. Permeability within basaltic oceanic crust. Rev. Geophys., 36(2):143-182. doi:10.1029/ 97RG02916

Heki, K., 2007. Secular, transient and seasonal crustal movements in Japan from a dense GPS array: implication for plate dynamics in convergent boundaries. In Dixon, T., and Moore, C. (Eds.), The Seismogenic Zone of Subduction Thrust Faults: New York (Columbia Univ. Press), 512-539.

Hoffman, N.W., and Tobin, H.J., 2004. An empirical relationship between velocity and porosity for underthrust sediments in the Nankai Trough accretionary prism. In Mikada, H., Moore, G.F., Taira, A., Becker, K., Moore, J.C., and Klaus, A. (Eds.), Proc. ODP, Sci. Results, 190/196: College Station, TX (Ocean Drilling Program), 1-23. doi:10.2973/odp.proc.sr.190196.355.2004

Hori, T., Kato, N., Hirahara, K., Baba, T., and Kaneda, Y., 2004. A numerical simulation of earthquake cycles along the Nankai Trough in southwest Japan: lateral variation in frictional property due to the slab geometry controls the nucleation position. Earth Planet. Sci. Lett., 228(3-4):215-226. doi:10.1016/j.epsl.2004.09.033

Ichinose, G.A., Thio, H.K., Somerville, P.G., Sato, T., and Ishii, T., 2003. Rupture process of the 1944 Tonankai earthquake $\left(M_{s} 8.1\right)$ from the inversion of teleseismic and regional seismograms. J. Geophys. Res., 108(B10):2497. doi:10.1029/2003JB002393

Ike, T., Moore, G.F., Kuramoto, S., Park, J-O., Kaneda, Y., and Taira, A., 2008a. Tectonics and sedimentation around Kashinosaki Knoll: a subducting basement high in the eastern Nankai Trough. Isl. Arc, 17(3):358-375. doi:10.1111/j.1440-1738.2008.00625.x 
Ike, T., Moore, G.F., Kuramoto, S., Park, J.-O., Kaneda, Y., and Taira, A., 2008b. Variations in sediment thickness and type along the northern Philippine Sea Plate at the Nankai Trough. Isl. Arc, 17(3):342-357. doi:10.1111/ j.1440-1738.2008.00624.X

Ito, Y., and Obara, K., 2006. Dynamic deformation of the accretionary prism excites very low frequency earthquakes. Geophys. Res. Lett., 33(2):LO2311. doi:10.1029/ 2005GL025270

Kagami, H., Karig, D.E., Coulbourn, W.T., et al., 1986. Init. Repts. DSDP, 87: Washington, DC (U.S. Govt. Printing Office). doi:10.2973/dsdp.proc.87.1986

Karig, D.E., Ingle, J.C., Jr., et al., 1975. Init. Repts. DSDP, 31: Washington, DC (U.S. Govt. Printing Office). doi:10.2973/dsdp.proc.31.1975

Kimura, J.-I., Stern, R.J., and Yoshida, T., 2005. Reinitiation of subduction and magmatic responses in SW Japan during Neogene time. Geol. Soc. Am. Bull., 117(78):969-986. doi:10.1130/B25565.1

Kobayashi, K., Kasuga, S., and Okino, K., 1995. Shikoku Basin and its margins. In Taylor, B. (Ed.), Backarc Basins: Tectonics and Magmatism: New York (Plenum), 381-405.

Kopf, A., and Brown, K.M., 2003. Friction experiments on saturated sediments and their implications for the stress state of the Nankai and Barbados subduction thrusts. Mar. Geol., 202(3-4):193-210. doi:10.1016/S00253227(03)00286-X

Le Pichon, X., Iiyama, T., Chamley, H., Charvet, J., Faure, M., Fujimoto, H., Furuta, T., Ida, Y., Kagami, H., Lallemant, S., Leggett, J., Murata, A., Okada, H., Rangin, C., Renard, V., Taira, A., and Tokuyama, H., 1987. Nankai Trough and the fossil Shikoku Ridge: results of Box 6 Kaiko survey. Earth Planet. Sci. Lett., 83(1-4):186-198. doi:10.1016/0012-821X(87)90065-3

Marsaglia, K.M., Ingersoll, R.V., and Packer, B.M., 1992. Tectonic evolution of the Japanese Islands as reflected in modal compositions of Cenozoic forearc and backarc sand and sandstone. Tectonics, 11(5):1028-1044. doi:10.1029/91TC03183

Mazzotti, S., Lallemant, S.J., Henry, P., Le Pichon, X., Tokuyama, H., and Takahashi, N., 2002. Intraplate shortening and underthrusting of a large basement ridge in the eastern Nankai subduction zone. Mar. Geol., 187(1-2):63-88. doi:10.1016/S0025-3227(02)00245-1

Mikada, H., Becker, K., Moore, J.C., Klaus, A., et al., 2002. Proc. ODP, Init. Repts., 196: College Station, TX (Ocean Drilling Program). doi:10.2973/odp.proc.ir.196.2002

Miyazaki, S., and Heki, K., 2001. Crustal velocity field of southwest Japan: subduction and arc-arc collision. J. Geophys. Res., 106(B3):4305-4326. doi:10.1029/ 2000JB900312

Moore, G.F., Bangs, N.L., Taira, A., Kuramoto, S., Pangborn, E., and Tobin, H.J., 2007. Three-dimensional splay fault geometry and implications for tsunami generation. Science, 318(5853):1128-1131. doi:10.1126/science.1147195

Moore, G.F., Park, J.-O., Bangs, N.L., Gulick, S.P., Tobin, H.J., Nakamura, Y., Sato, S., Tsuji, T., Yoro, T., Tanaka, H., Uraki, S., Kido, Y., Sanada, Y., Kuramoto, S., and
Taira, A., 2009. Structural and seismic stratigraphic framework of the NanTroSEIZE Stage 1 transect. In Kinoshita, M., Tobin, H., Ashi, J., Kimura, G., Lallemant, S., Screaton, E.J., Curewitz, D., Masago, H., Moe, K.T., and the Expedition 314/315/316 Scientists, Proc. IODP, 314/315/316: Washington, DC (Integrated Ocean Drilling Program Management International, Inc.). doi:10.2204/iodp.proc.314315316.102.2009

Moore, G.F., Taira, A., Klaus, A., Becker, L., Boeckel, B., Cragg, B.A., Dean, A., Fergusson, C.L., Henry, P., Hirano, S., Hisamitsu, T., Hunze, S., Kastner, M., Maltman, A.J., Morgan, J.K., Murakami, Y., Saffer, D.M., SánchezGómez, M., Screaton, E.J., Smith, D.C., Spivack, A.J., Steurer, J., Tobin, H.J., Ujiie, K., Underwood, M.B., and Wilson, M., 2001. New insights into deformation and fluid flow processes in the Nankai Trough accretionary prism: results of Ocean Drilling Program Leg 190. Geochem., Geophys., Geosyst., 2(10):1058. doi:10.1029/ 2001GC000166

Moore, G.F., Taira, A., Klaus, A., et al., 2001. Proc. ODP, Init. Repts., 190: College Station, TX (Ocean Drilling Program). doi:10.2973/odp.proc.ir.190.2001

Moore, J.C., and Saffer, D., 2001. Updip limit of the seismogenic zone beneath the accretionary prism of southwest Japan: an effect of diagenetic to low-grade metamorphic processes and increasing effective stress. Geology, 29(2):183-186. doi:10.1130/00917613(2001)029<0183:ULOTSZ>2.0.CO;2

Muck, M., and Underwood, M., 1990. Upslope flow of turbidity currents: a comparison among field observations, theory, and laboratory models. Geology, 18(1):54-57. doi:10.1130/0091-7613(1990)018<0054:UFOTCA $>2.3 . \mathrm{CO} ; 2$

Nakajima, T., 1997. Regional metamorphic belts of the Japanese Islands. Isl. Arc, 6(1):69-90. doi:10.1111/j.14401738.1997.tb00041.x

Obana, K., Kodaira, S., and Kaneda, Y., 2004. Microseismicity around rupture area of the 1944 Tonankai earthquake from ocean bottom seismograph observations. Earth Planet. Sci. Lett., 222(2):561-572. doi:10.1016/ j.epsl.2004.02.032

Obara, K., and Ito, Y., 2005. Very low frequency earthquakes excited by the 2004 off the Kii Peninsula earthquakes: a dynamic deformation process in the large accretionary prism. Earth, Planets Space, 57(4):321-326.

Okino, K., Shimakawa, Y., and Nagaoka, S., 1994. Evolution of the Shikoku Basin. J. Geomagn. Geoelectr., 46:463-479.

Park, J.-O., Tsuru, T., Kodaira, S., Cummins, P.R., and Kaneda, Y., 2002. Splay fault branching along the Nankai subduction zone. Science, 297(5584):1157-1160. doi:10.1126/science.1074111

Park, J.-O., Tsuru, T., No, T., Takizawa, K., Sato, S., and Kaneda, Y., 2008. High-resolution 3D seismic reflection survey and prestack depth imaging in the Nankai Trough off southeast Kii Peninsula. Butsuri Tansa, 61:231-241. (in Japanese, with abstract in English)

Saffer, D., McNeill, L., Araki, E., Byrne, T., Eguchi, N., Toczko, S., Takahashi, K., and the Expedition 319 Scientists, 
2009. NanTroSEIZE Stage 2: NanTroSEIZE riser/riserless observatory. IODP Prel. Rept., 319. doi:10.2204/ iodp.pr.319.2009

Saffer, D.M., and Bekins, B.A., 2006. An evaluation of factors influencing pore pressure in accretionary complexes: implications for taper angle and wedge mechanics. J. Geophys. Res., [Solid Earth], 111(B4):B04101. doi:10.1029/2005JB003990

Saffer, D.M., and Marone, C., 2003. Comparison of smectite- and illite-rich gouge frictional properties: application to the updip limit of the seismogenic zone along subduction megathrusts. Earth Planet. Sci. Lett., 215(12):219-235. doi:10.1016/S0012-821X(03)00424-2

Saffer, D.M., and McKiernan, A.W., 2009. Evaluation of in situ smectite dehydration as a pore water freshening mechanism in the Nankai Trough, offshore southwest Japan. Geochem., Geophys. Geosys., 10(2):Q02010. doi:10.1029/2008GC002226

Saffer, D.M., Underwood, M.B., and McKiernan, A.W., 2008. Evaluation of factors controlling smectite transformation and fluid production in subduction zones: application to the Nankai Trough. Isl. Arc, 17(2):208230. doi:10.1111/j.1440-1738.2008.00614.X

Saito, S., Underwood, M.B., and Kubo, Y., 2009. NanTroSEIZE Stage 2: subduction inputs. IODP Sci. Prosp., 322. doi:10.2204/iodp.sp.322.2009

Screaton, E.J., Kimura, G., Curewitz, D., and the Expedition 316 Scientists, 2009. Expedition 316 summary. In Kinoshita, M., Tobin, H., Ashi, J., Kimura, G., Lallemant, S., Screaton, E.J., Curewitz, D., Masago, H., Moe, K.T., and the Expedition 314/315/316 Scientists, Proc. IODP, 314/315/316: Washington, DC (Integrated Ocean Drilling Program Management International, Inc.). doi:10.2204/iodp.proc.314315316.131.2009

Scudder, R.P., Murray, R.W., and Plank, T., 2009. Dispersed ash in deeply buried sediment from the northwest Pacific Ocean: an example from the Izu-Bonin arc (ODP Site 1149). Earth Planet. Sci. Lett., 284(3-4):639-648. doi:10.1016/j.epsl.2009.05.037

Seno, T., Stein, S., and Gripp, A.E., 1993. A model for the motion of the Philippine Sea plate consistent with NUVEL-1 and geological data. J. Geophys. Res., 98(B10):17941-17948. doi:10.1029/93JB00782

Spinelli, G.A., Mozley, P.S., Tobin, H.J., Underwood, M.B., Hoffman, N.W., and Bellew, G.M., 2007. Diagenesis, sediment strength, and pore collapse in sediment approaching the Nankai Trough subduction zone. Geol. Soc. Am. Bull., 119(3-4):377-390. doi:10.1130/ B25920.1

Spinelli, G.A., and Underwood, M.B., 2005. Modeling thermal history of subducting crust in Nankai Trough: constraints from in situ sediment temperature and diagenetic reaction progress. Geophys. Res. Lett., 32(9):L09301. doi:10.1029/2005GL022793

Spinelli, G.A., and Wang, K., 2008. Effects of fluid circulation in subduction crust on Nankai margin seismogenic zone temperatures. Geology, 36(11):887-890. doi:10.1130/G25145A.1
Swarbrick, R.E., and Osborne, M.J., 1998. Mechanisms that generate abnormal pressures: an overview. In Law, B.E., Ulmishek, G.F., and Slavin, V.I. (Eds.), Abnormal Pressures in Hydrocarbon Environments. AAPG Mem., 70:13-34.

Taira, A., Hill, I., Firth, J., Berner, U., Brückmann, W., Byrne, T., Chabernaud, T., Fisher, A., Foucher, J.-P., Gamo, T., Gieskes, J., Hyndman, R., Karig, D., Kastner, M., Kato, Y., Lallement, S., Lu, R., Maltman, A., Moore, G., Moran, K., Olaffson, G., Owens, W., Pickering, K., Siena, F., Taylor, E., Underwood, M., Wilkinson, C., Yamano, M., and Zhang, J., 1992. Sediment deformation and hydrogeology of the Nankai Trough accretionary prism: synthesis of shipboard results of ODP Leg 131. Earth Planet. Sci. Lett., 109(3-4):431-450. doi:10.1016/0012-821X(92)90104-4

Taira, A., Hill, I., Firth, J.V., et al., 1991. Proc. ODP, Init. Repts., 131: College Station, TX (Ocean Drilling Program). doi:10.2973/odp.proc.ir.131.1991

Taira, A., Tokuyama, H., and Soh, W., 1989. Accretion tectonics and evolution of Japan. In Ben-Avraham, Z. (Ed.), The Evolution of the Pacific Ocean Margins: Oxford (Oxford Univ. Press), 100-123.

Tanioka, Y., and Satake, K., 2001. Detailed coseismic slip distribution of the 1944 Tonankai earthquake estimated from tsunami waveforms. Geophys. Res. Lett., 28(6):1075-1078. doi:10.1029/2000GL012284

Taylor, B., 1992. Rifting and the volcanic-tectonic evolution of the Izu-Bonin-Mariana arc. In Taylor, B., Fujioka, K., et al., Proc. ODP, Sci. Results, 126: College Station, TX (Ocean Drilling Program), 627-651. doi:10.2973/ odp.proc.sr.126.163.1992

Tobin, H., Kinoshita, M., Ashi, J., Lallemant, S., Kimura, G., Screaton, E.J., Moe, K.T., Masago, H., Curewitz, D., and the Expedition 314/315/316 Scientists, 2009. NanTroSEIZE Stage 1 expeditions: introduction and synthesis of key results. In Kinoshita, M., Tobin, H., Ashi, J., Kimura, G., Lallemant, S., Screaton, E.J., Curewitz, D., Masago, H., Moe, K.T., and the Expedition 314/315/316 Scientists, Proc. IODP, 314/315/316: Washington, DC (Integrated Ocean Drilling Program Management International, Inc.). doi:10.2204/ iodp.proc.314315316.101.2009

Tobin, H.J., and Kinoshita, M., 2006a. Investigations of seismogenesis at the Nankai Trough, Japan. IODP Sci. Prosp., NanTroSEIZE Stage 1. doi:10.2204/ iodp.sp.nantroseize1.2006

Tobin, H.J., and Kinoshita, M., 2006b. NanTroSEIZE: the IODP Nankai Trough Seismogenic Zone Experiment. Sci. Drill., 2:23-27. doi:10.2204/iodp.sd.2.06.2006

Underwood, M.B., 2007. Sediment inputs to subduction zones: why lithostratigraphy and clay mineralogy matter. In Dixon, T., and Moore, J.C. (Eds.), The Seismogenic Zone of Subduction Thrust Faults: New York (Columbia Univ. Press), 42-85.

Underwood, M.B., and Fergusson, C.L., 2005, Late Cenozoic evolution of the Nankai trench-slope system: Evidence from sand petrography and clay mineralogy. In Hodgson, D., and Flint, S. (Eds.), Submarine Slope Systems: Processes, Products and Prediction. Geol. Soc. Spec. 
Publ., 244(1):113-129. doi:10.1144/

GSL.SP.2005.244.01.07

Underwood, M.B., and Steurer, J.F., 2003. Composition and sources of clay from the trench slope and shallow accretionary prism of Nankai Trough. In Mikada, H., Moore, G.F., Taira, A., Becker, K., Moore, J.C., and Klaus, A. (Eds.), Proc. ODP, Sci. Results, 190/196: College Station, TX (Ocean Drilling Program), 1-28. doi:10.2973/ odp.proc.sr.190196.206.2003

Vrolijk, P., 1990. On the mechanical role of smectite in subduction zones. Geology, 18(8):703-707. doi:10.1130/ 0091-7613(1990)018<0703:OTMROS >2.3.CO;2

Wang, K., Hyndman, R.D., and Yamano, M., 1995. Thermal regime of the southwest Japan subduction zone: effects of age history of the subducting plate. Tectonophysics, 248(1-2):53-69. doi:10.1016/00401951(95)00028-L
Wheat, C.G., Jannasch, H.W., Kastner, M., Plant, J.N., and DeCarlo, E.H., 2003. Seawater transport and reaction in upper oceanic basaltic basement: chemical data from continuous monitoring of sealed boreholes in a ridge flank environment. Earth Planet. Sci. Lett., 216(4):549564. doi:10.1016/S0012-821X(03)00549-1

Yamano, M., Kinoshita, M., Goto, S., and Matsubayashi, O., 2003. Extremely high heat flow anomaly in the middle part of the Nankai Trough. Phys. Chem. Earth, 28(911):487-497. doi:10.1016/S1474-7065(03)00068-8

Yamazaki, T., and Okamura, Y., 1989. Subducting seamounts and deformation of overriding forearc wedges around Japan. Tectonophysics, 160(1-4):207-217. doi:10.1016/0040-1951(89)90392-2

Publication: 10 October 2010 MS 322-101 
Figure F1. Bathymetric map, Nankai Trough off southwestern Japan is the locus of subduction of the Philippine Sea plate (PSP) beneath Honshu and Shikoku islands. Yellow arrows = estimated far-field vectors between the Philippine Sea plate and Japan (Seno et al. 1993; Heki, 2007). Rupture zones of last two large subduction earthquakes (1944 and 1946) are also shown. Stars = epicenter locations for earthquake nucleation. Red dashed line = Expedition 322 drilling area shown in Figure F2. Inset shows location of Nankai Trough. Previous transects of Nankai Trough were positioned off Ashizuri and Muroto peninsulas of Shikoku. EP = Eurasian plate, PP = Pacific plate, NAP = North American plate.

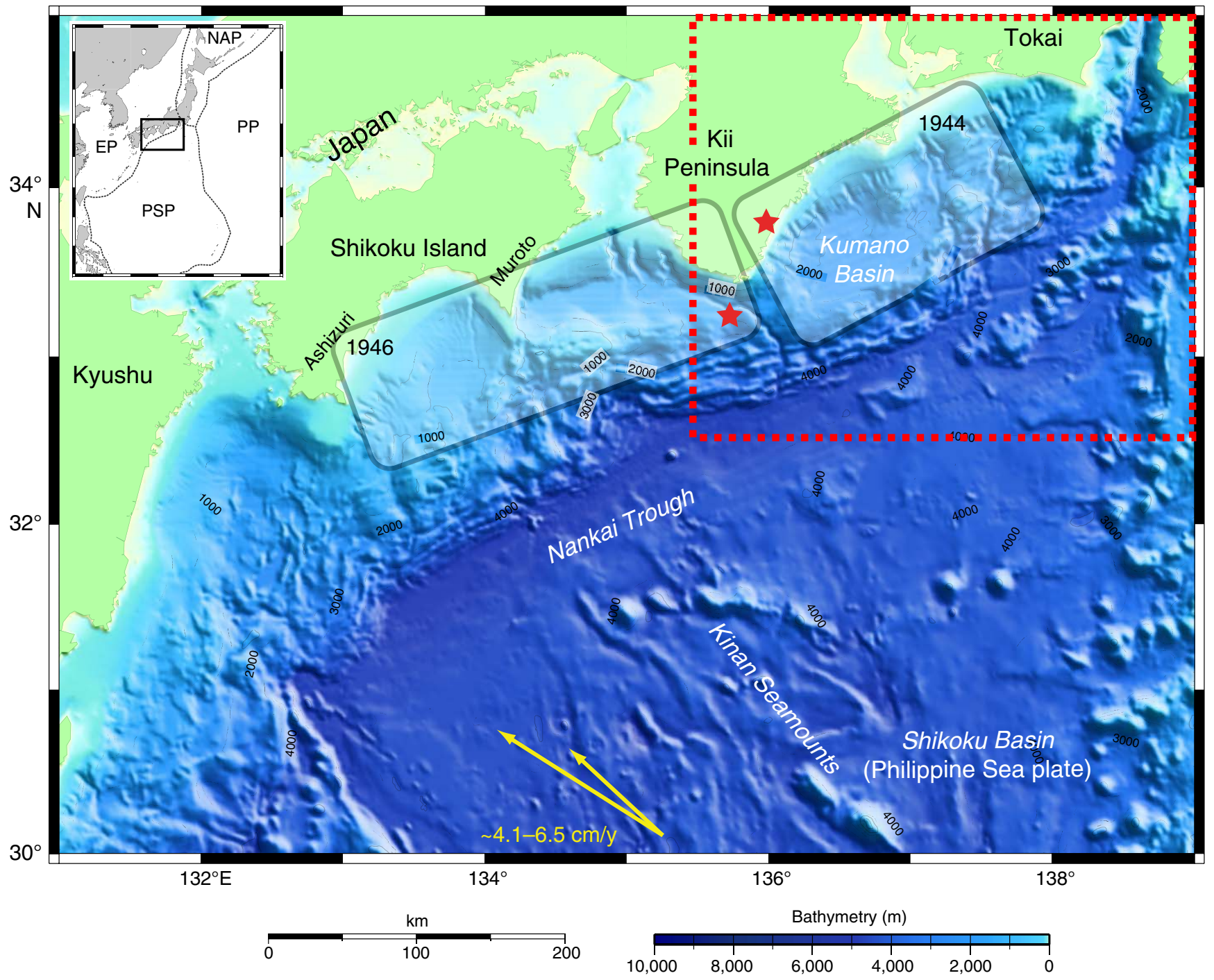


Figure F2. Bathymetric map, with 2-D multichannel seismic profile locations and Stage 1 drill sites (orange). Expedition 322 drilled Sites C0011 (red) and C0012 (white). White barbed line = position of deformation front of accretionary prism, yellow arrows = estimated far-field vectors between the Philippine Sea plate and Japan (Seno et al. 1993; Heki, 2007).

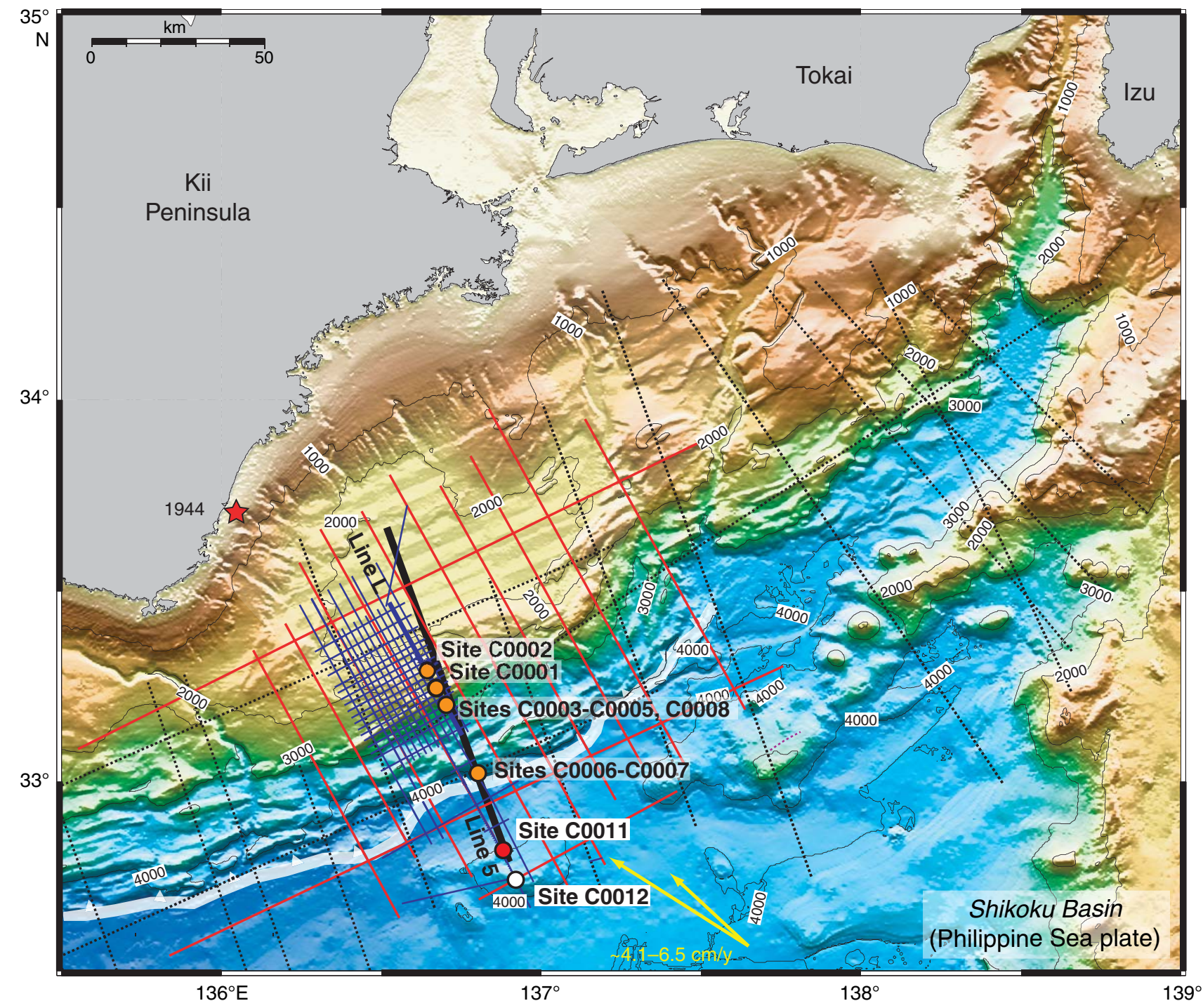


Figure F3. Spliced composite profile of a representative depth section from NanTroSEIZE 3-D data volume (Moore et al., 2009) and Line 95 from IFREE mini-3-D seismic survey (Park et al., 2008). Projected positions of Stages 1 and 2 drilling sites including Sites C0011 and C0012 are shown.

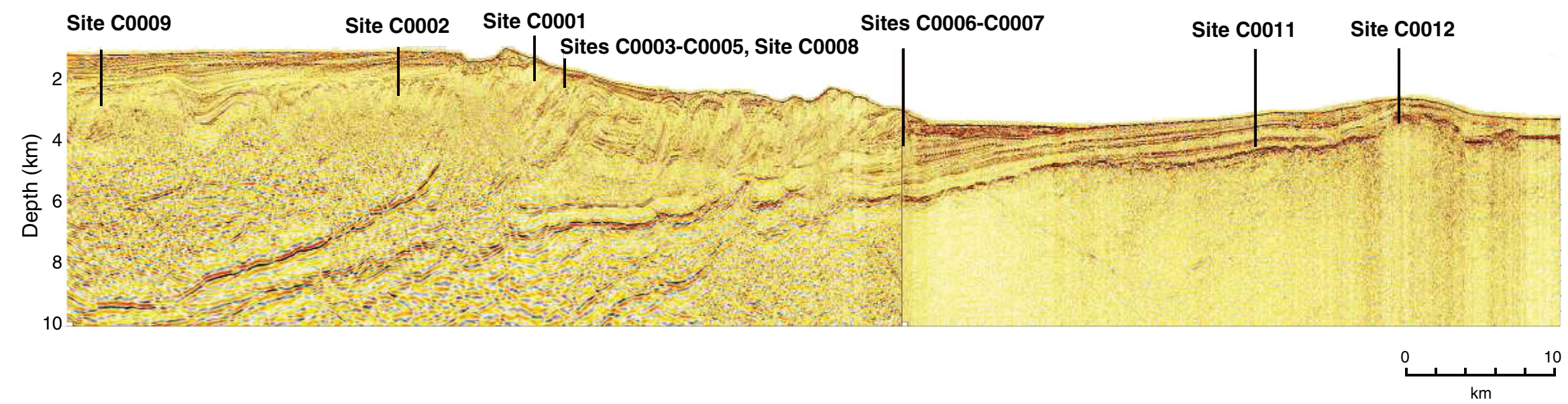


Figure F4. Portion of IFREE 3-D seismic reflection Line 95 showing Sites C0011 and C0012. Depth section corrected during Expedition 322 after adjustments to velocity model following acquisition of LWD data at Site C0011. VE = vertical exaggeration.

Common depth point

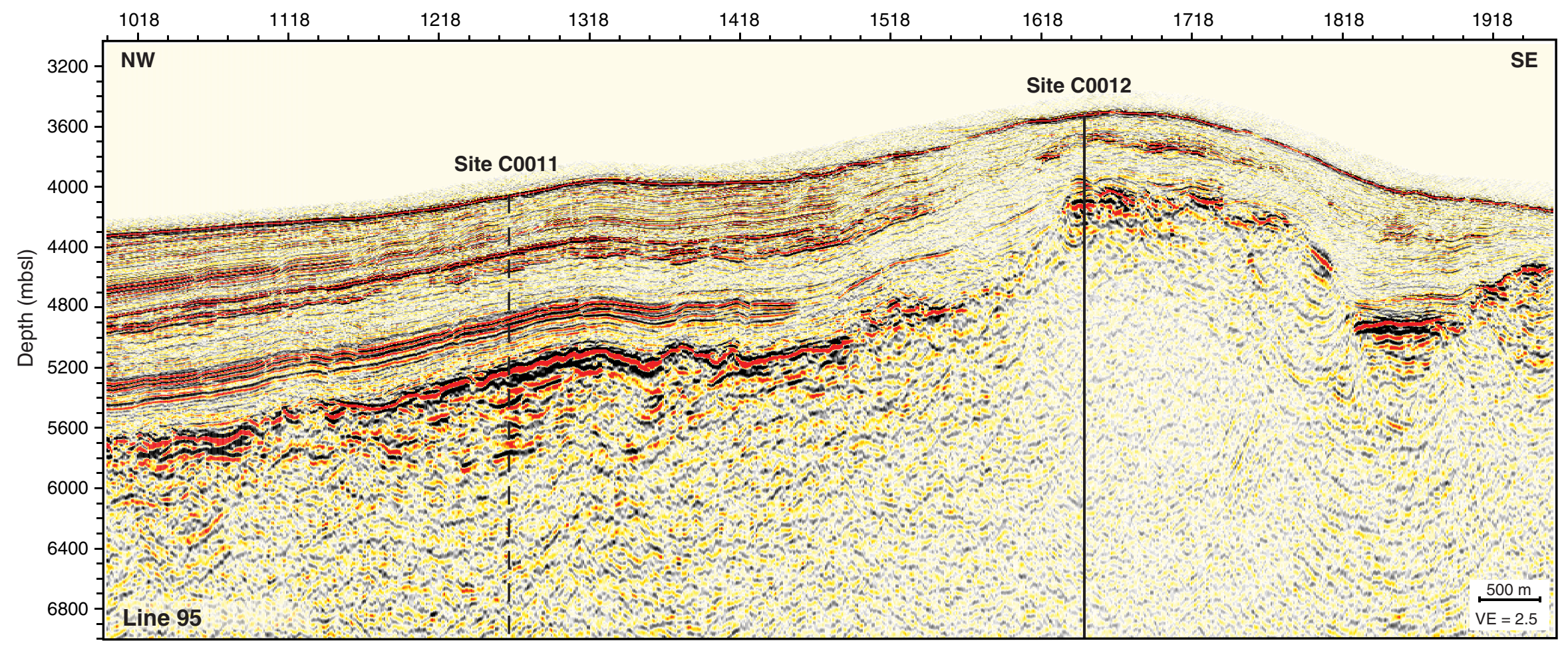


Figure F5. LWD log summary and log-seismic integration, Hole C0011A. Interpretations of lithology are based on log character. $\mathrm{VE}=$ vertical exaggeration.

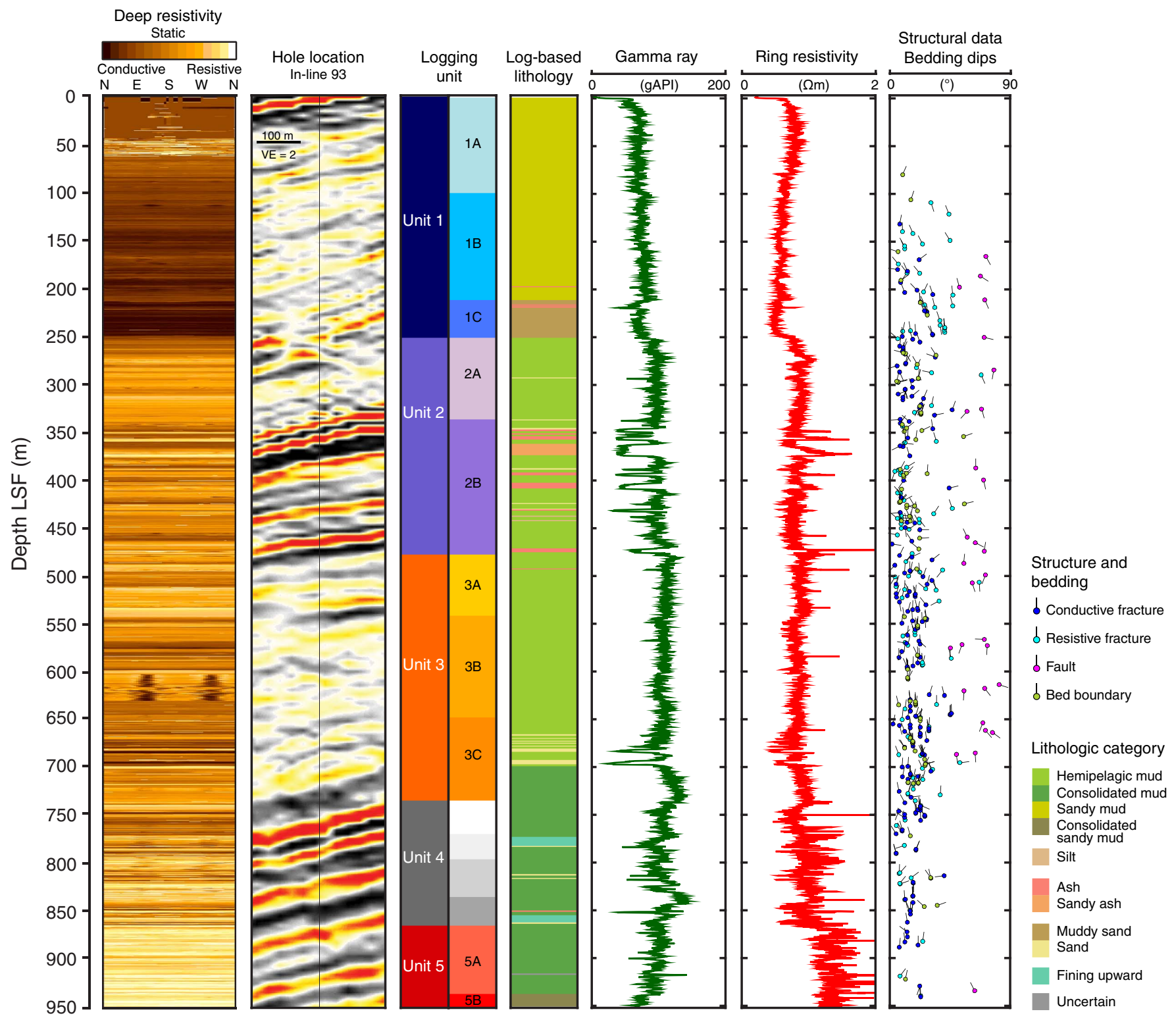


Figure F6. Seismic stratigraphy, Site C0011. VE = vertical exaggeration.
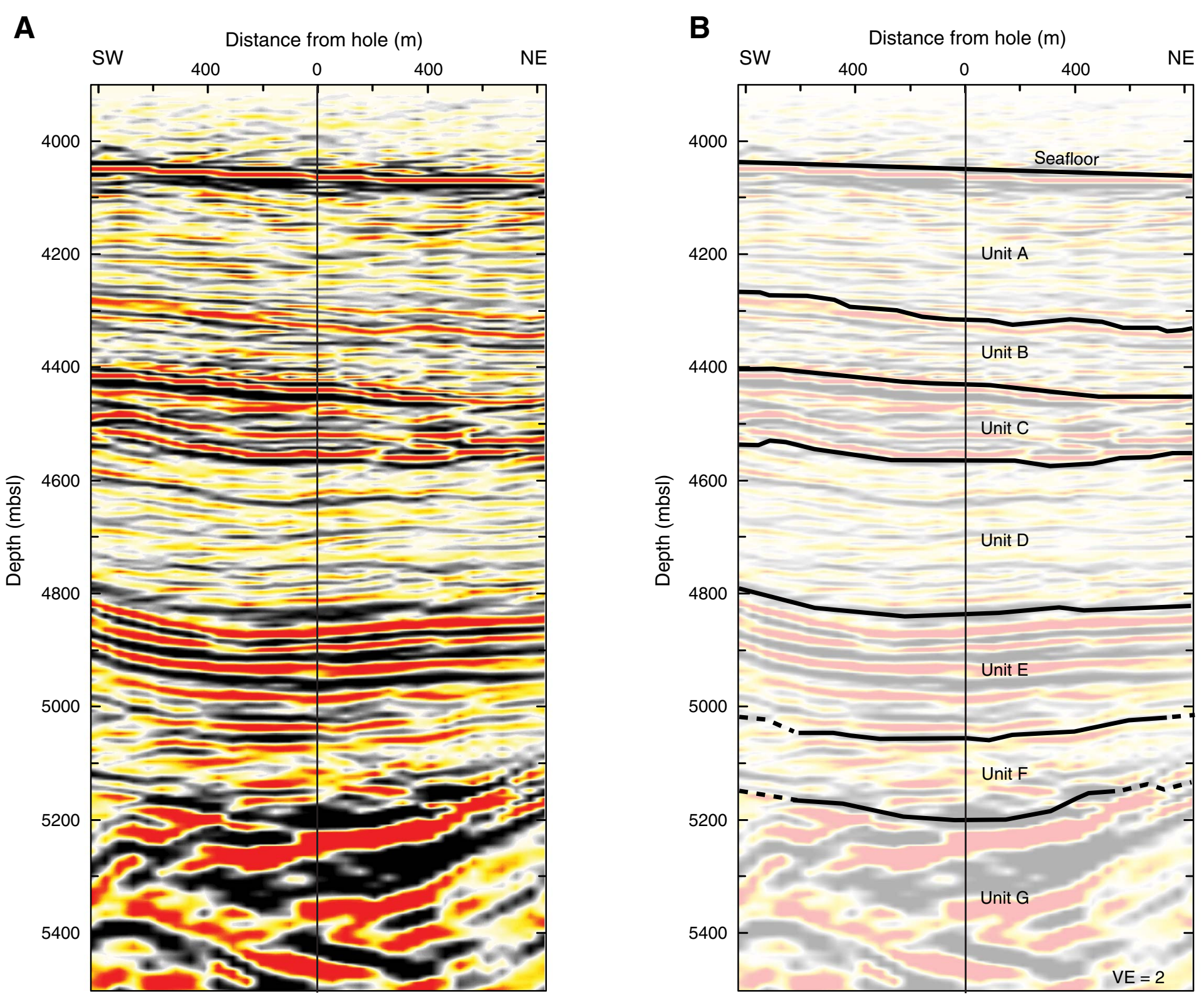
Figure F7. Comparison of lithology from core in lithologic Unit II, Hole C0011B, and log character on logging Unit 2B, Hole C0011A.

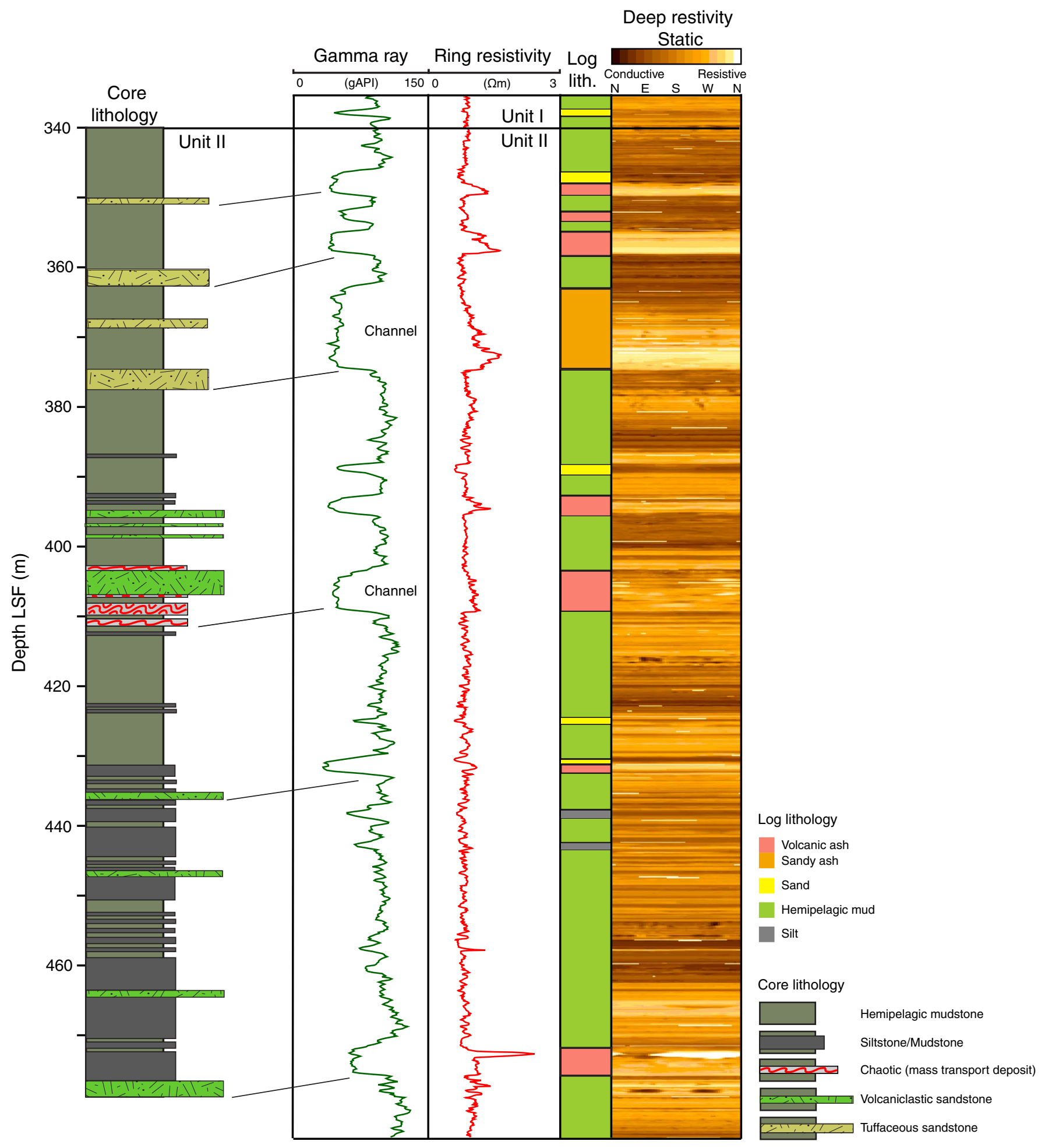


Figure F8. Lithologic column and core recovery, Hole C0011B.

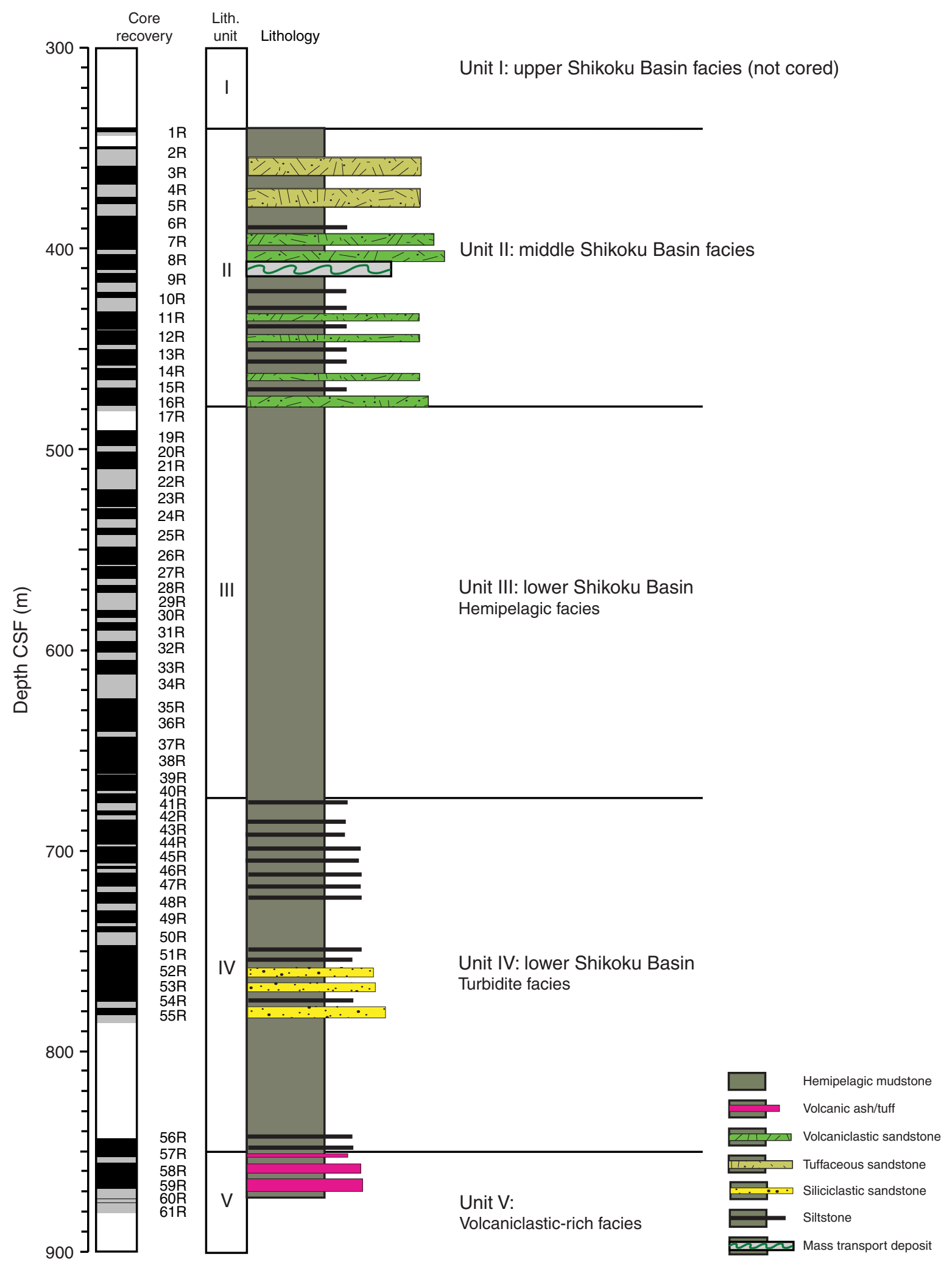


Figure F9. Lithologic units and depositional ages from nannofossil datums, Hole C0011B. Logging-whiledrilling data only from 0 to $340 \mathrm{~m}$ LSF.

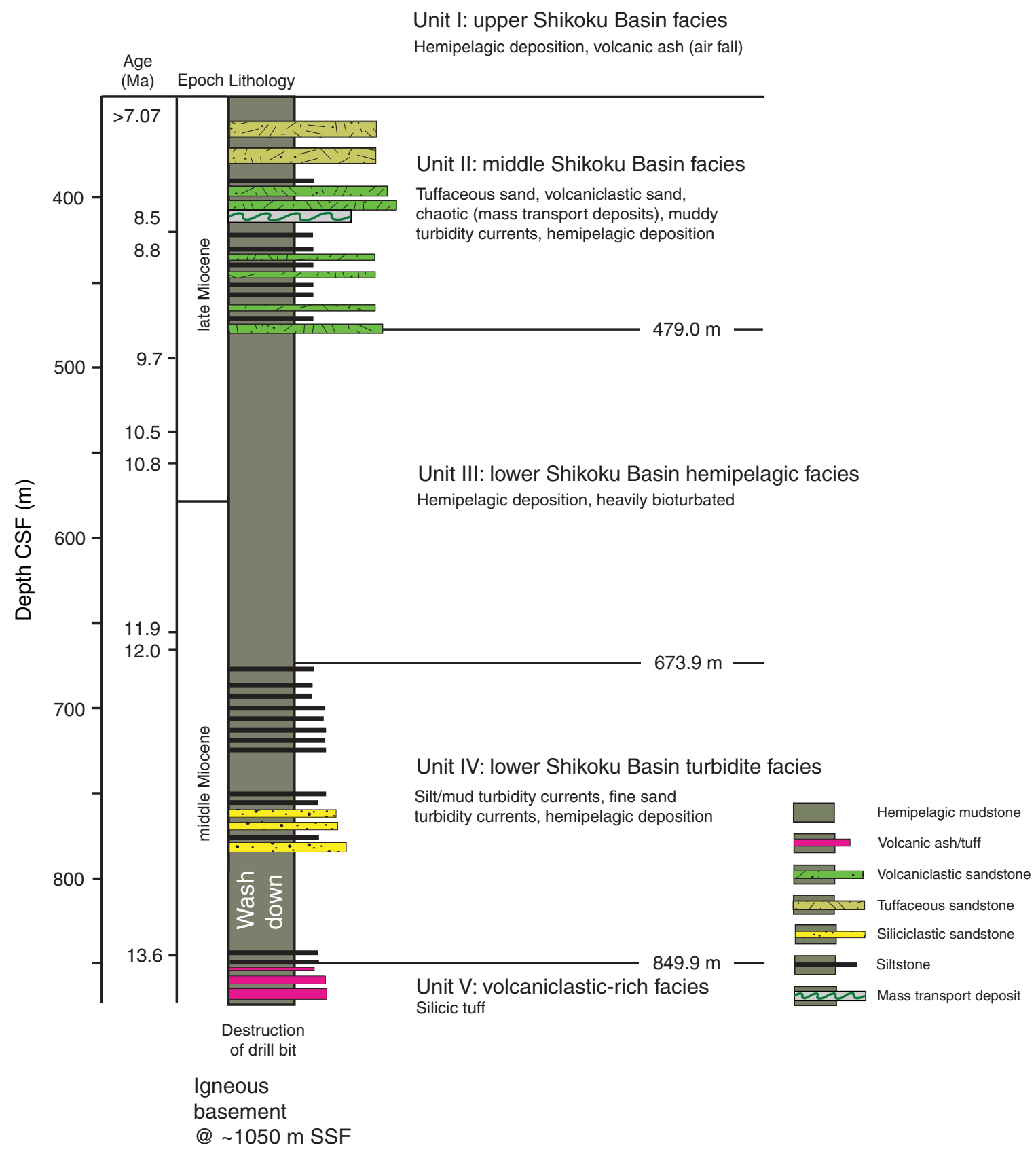


Figure F10. Photographs of (A) pyroclastic sandstone and (B) volcaniclastic sandstone from lithologic Unit II, Hole C0011B.

A

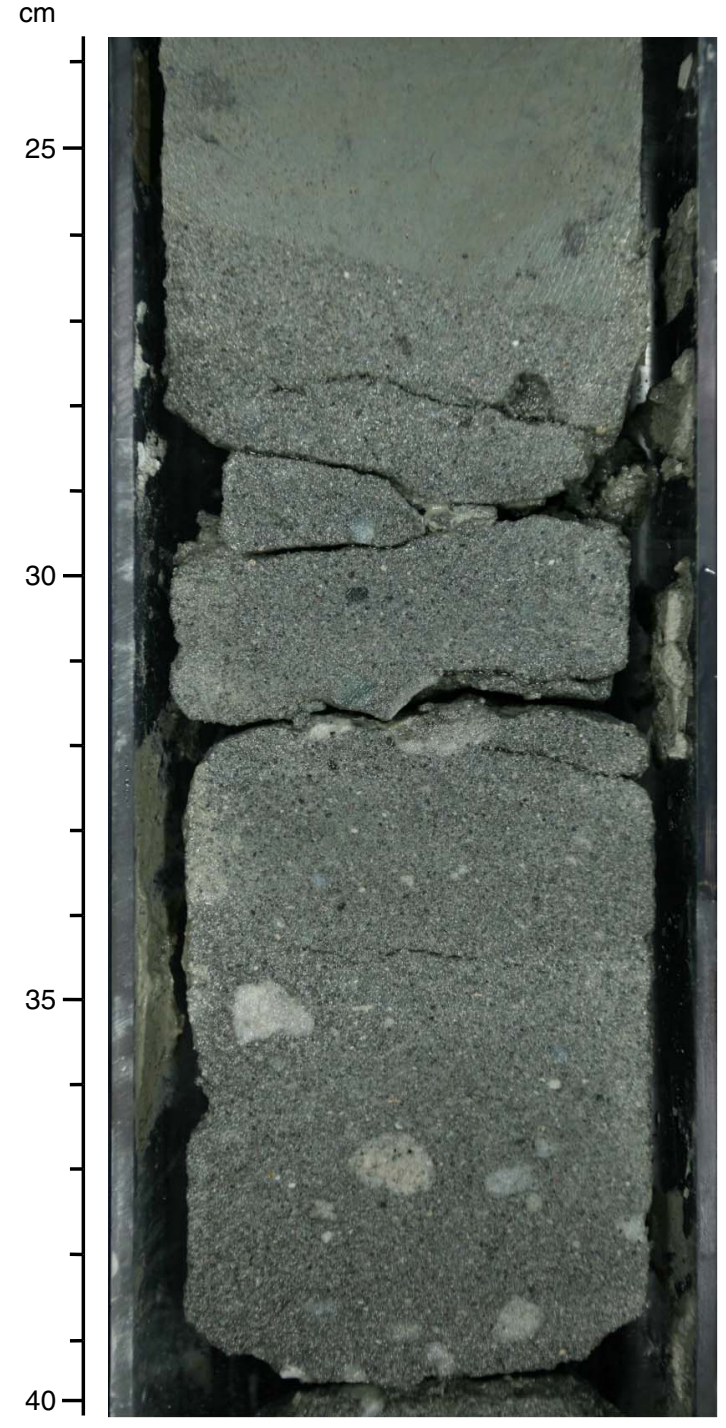

B

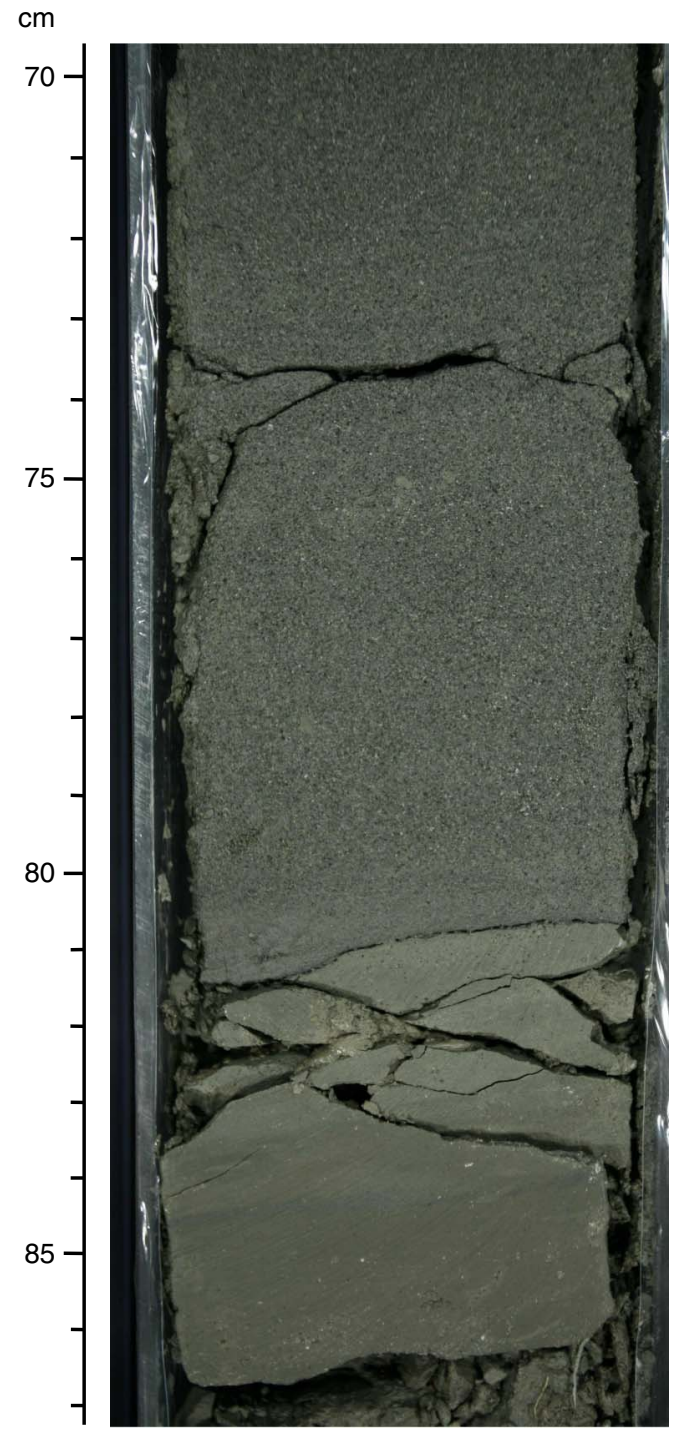


Figure F11. Bulk powder XRD profiles, Hole C0011B, reported in relative weight percent.

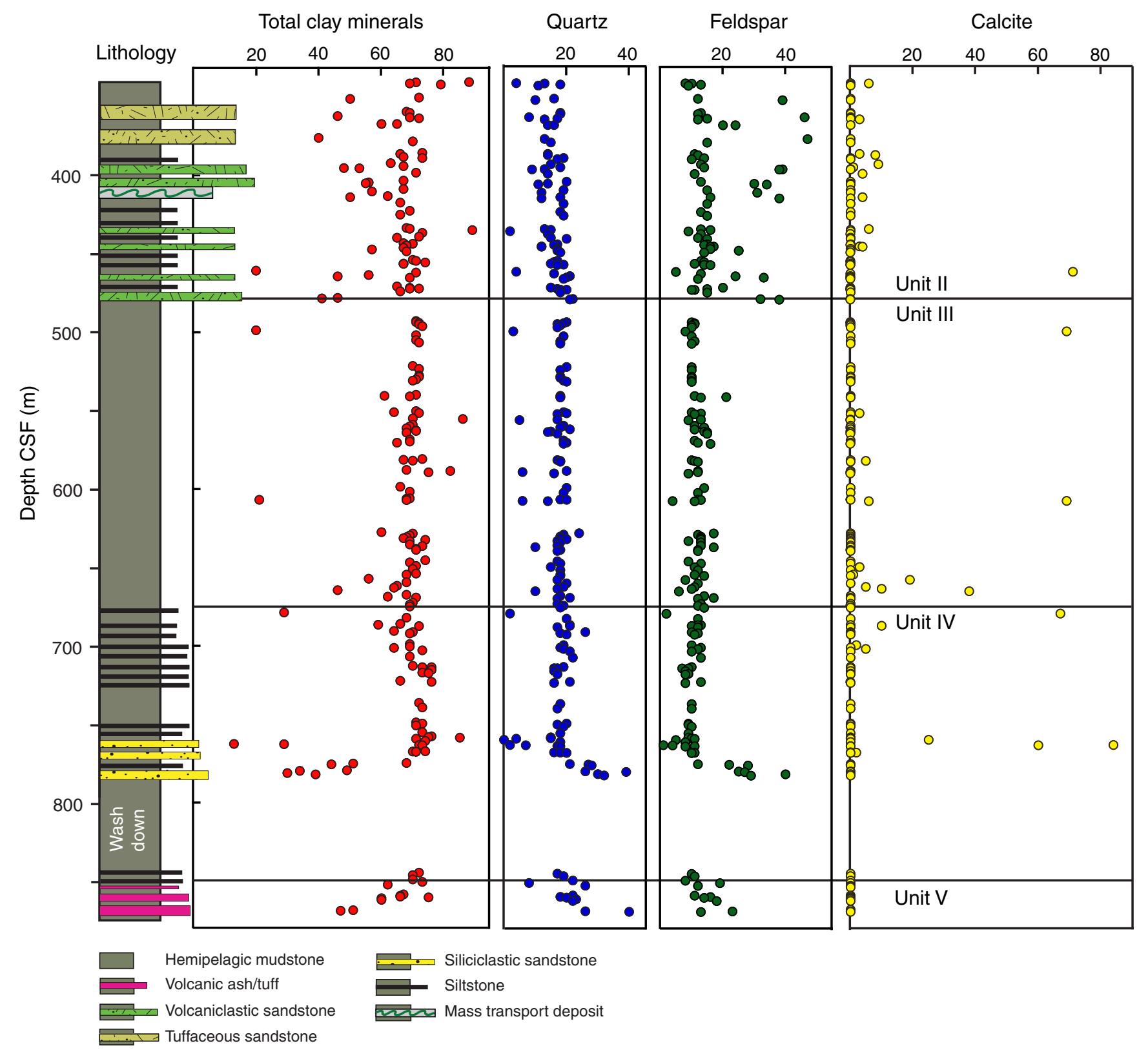


Figure F12. Bulk XRF profiles with values normalized to $\mathrm{Al}_{2} \mathrm{O}_{3}$, Hole C0011B.

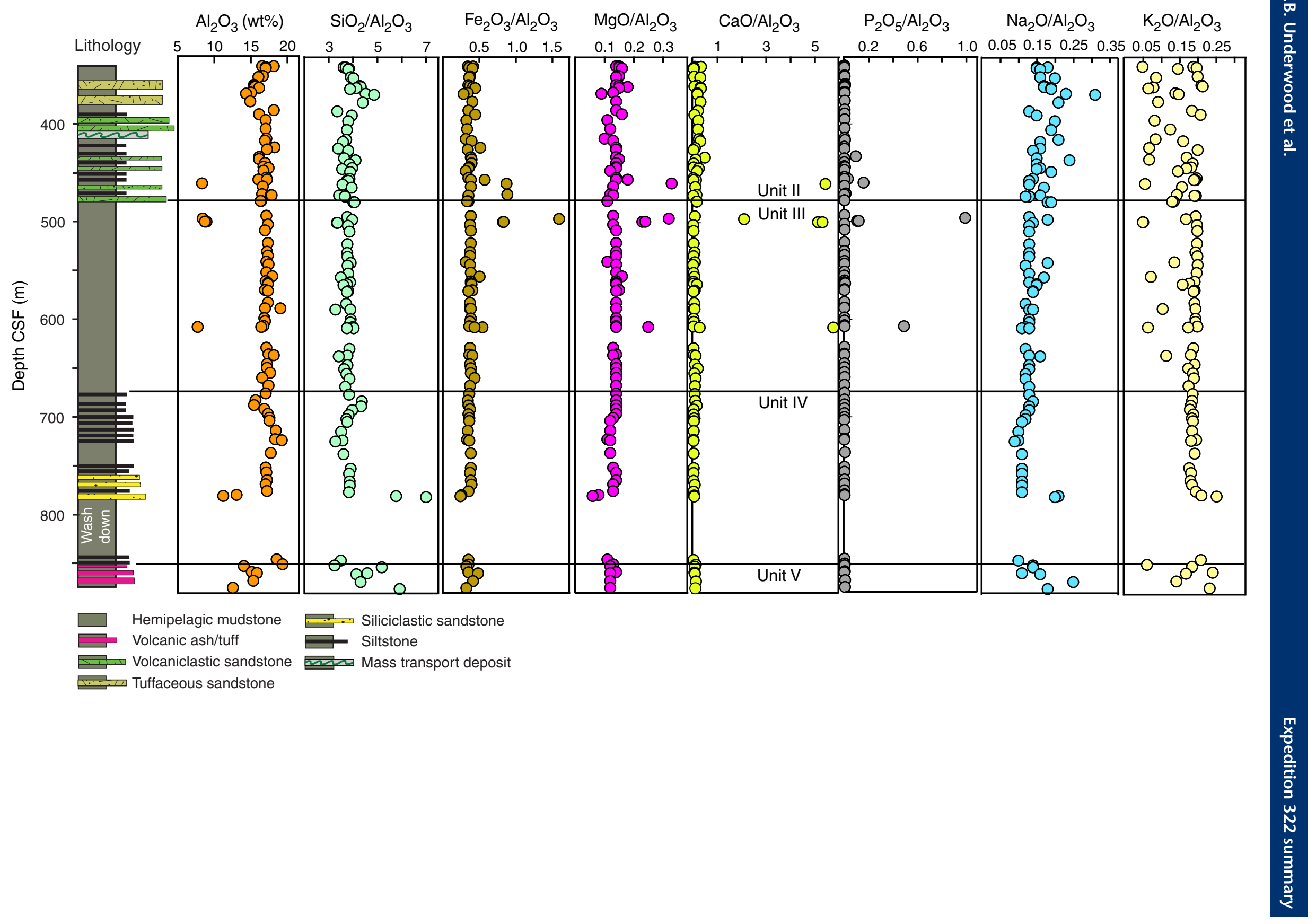


Figure F13. Rates of hemipelagic sedimentation corrected for rapid deposition by sediment gravity flows, Hole C0011B.

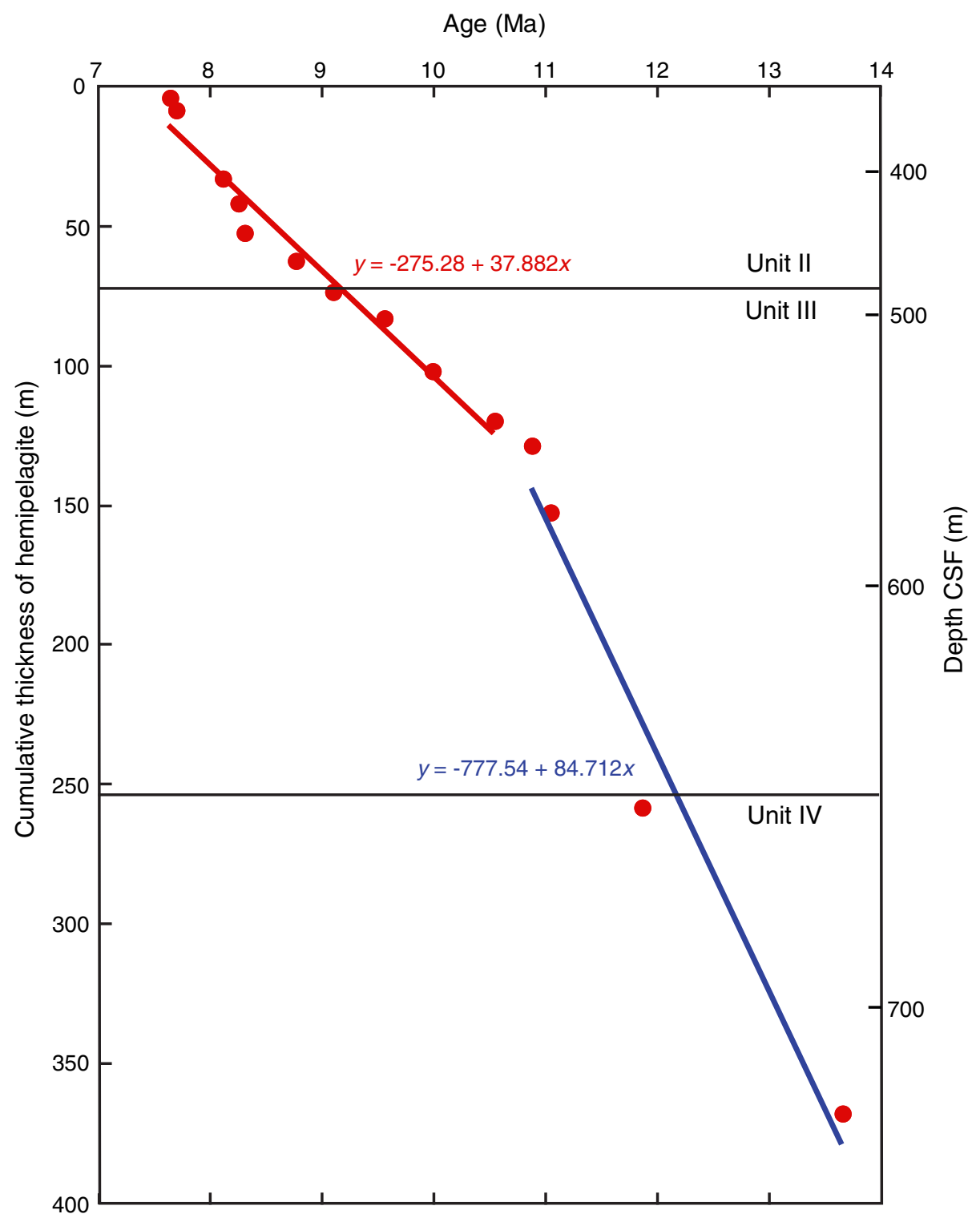




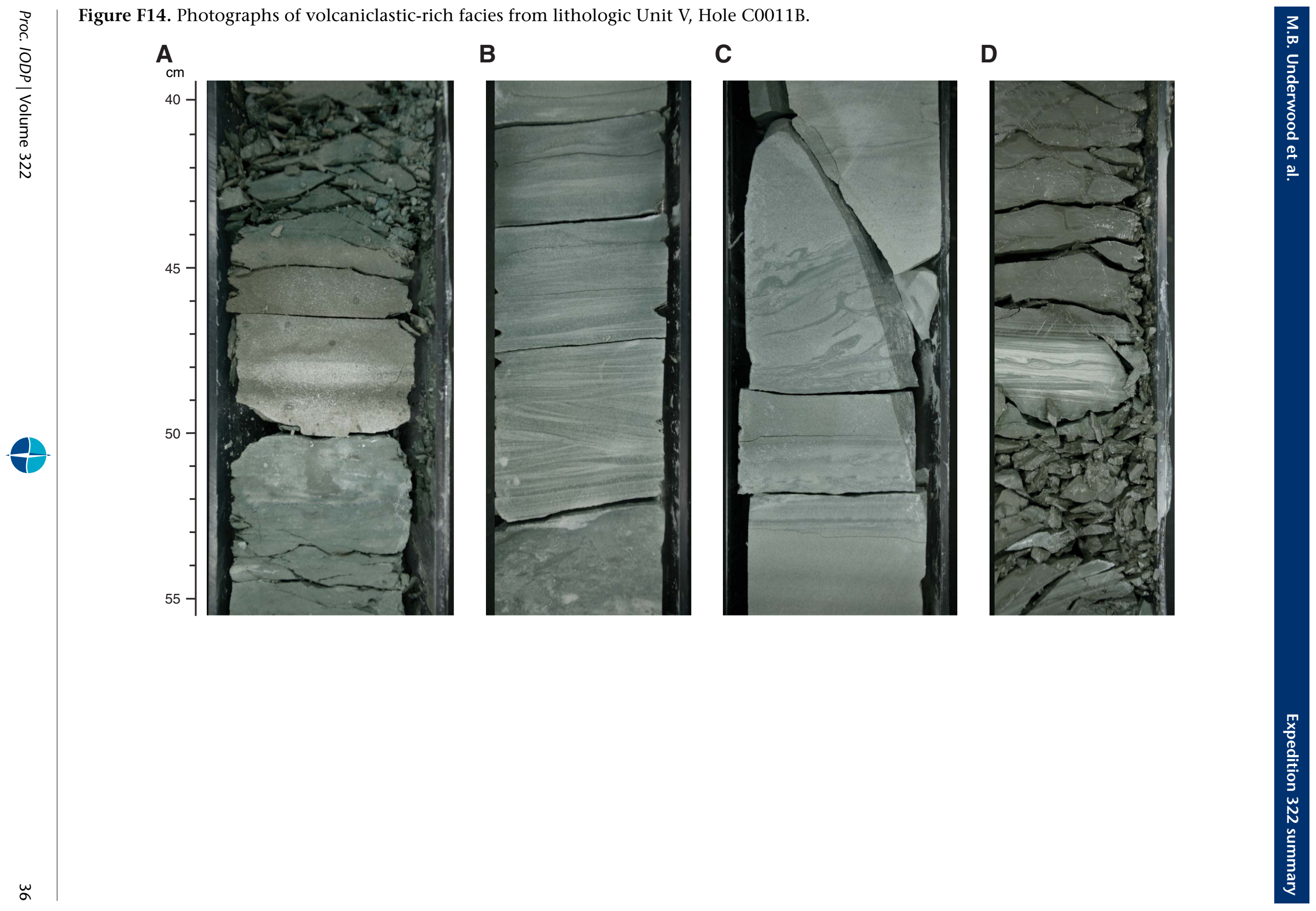


Figure F15. Orientation of planar structures, Hole C0011B, determined by direct measurement of split core and $\mathrm{X}$-ray computed tomography. Shaded bars = chaotic intervals.

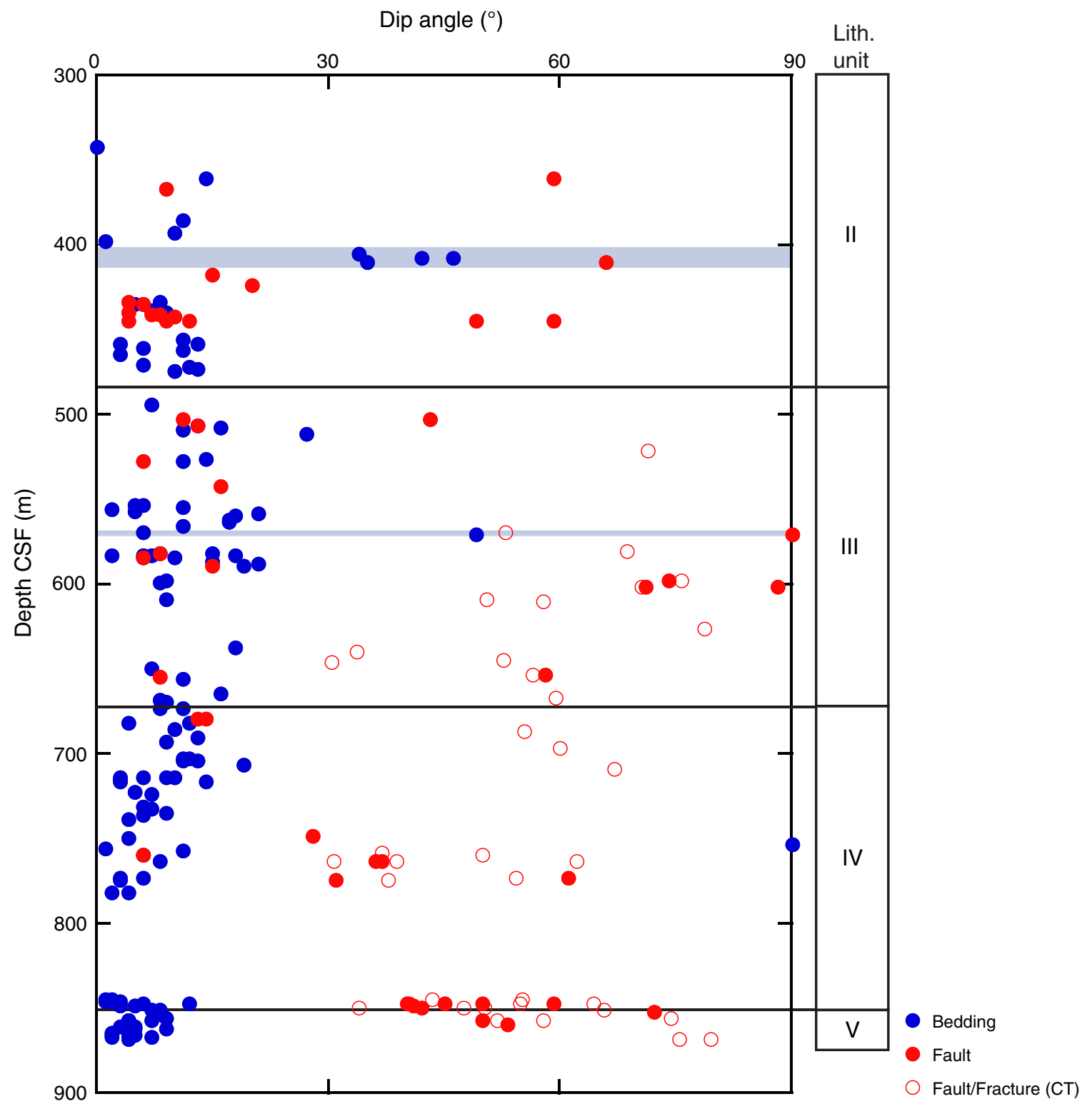


Figure F16. Integrated age-depth model, Hole C0011B. Unit boundary ages include errors of control points and line fitting.

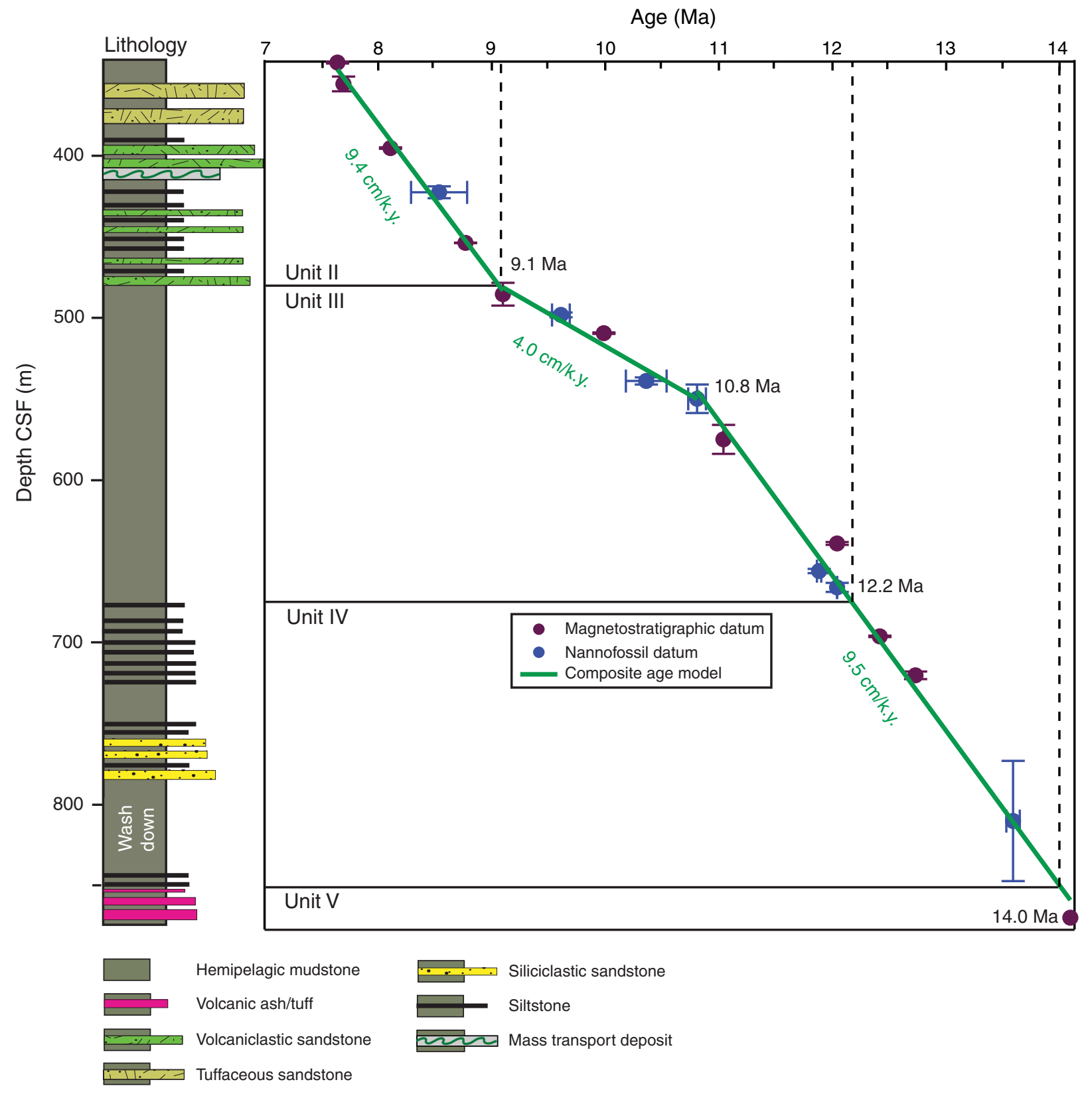


Figure F17. Comparison of magnetic susceptibility using MSCL and VCD from lithologic Unit II, Hole C0011B.

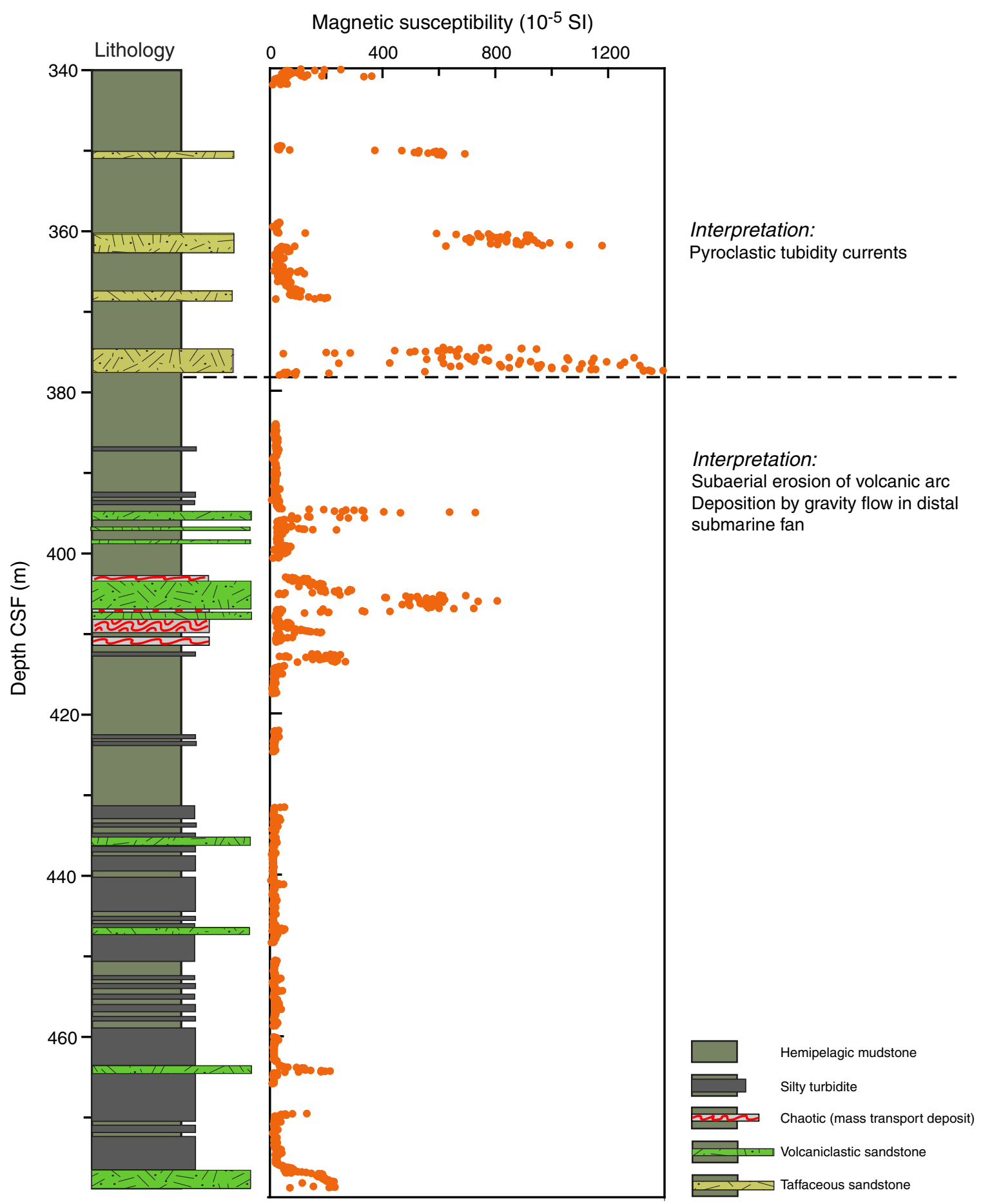


Figure F18. Discrete grain density, porosity, $P$-wave velocity, and thermal conductivity measurements for Hole C0011B. For thermal conductivity, $+=$ probe measurements, diamonds $=$ half-space measurements.
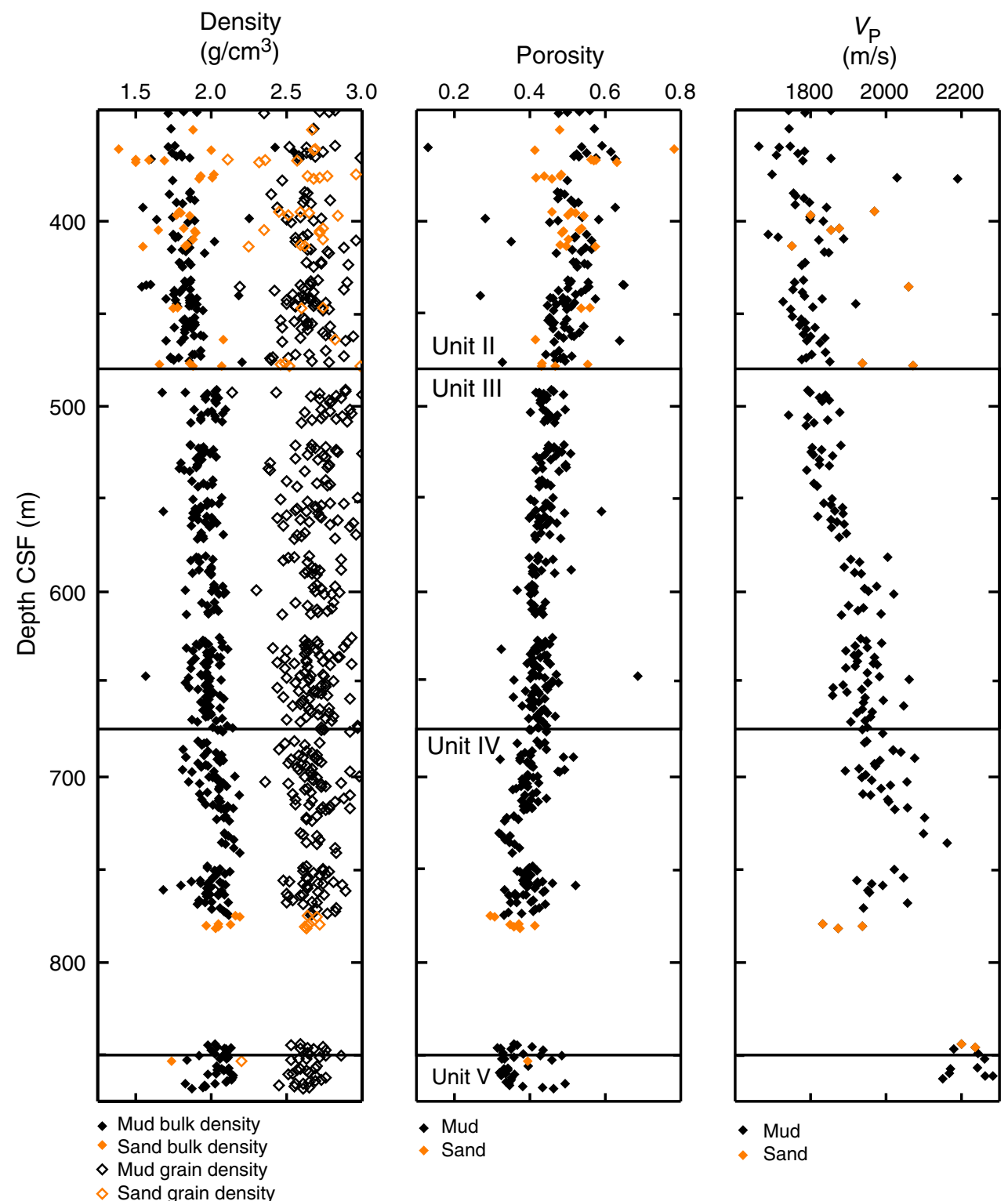

Thermal conductivity $(\mathrm{W} /[\mathrm{m} \cdot \mathrm{K}])$

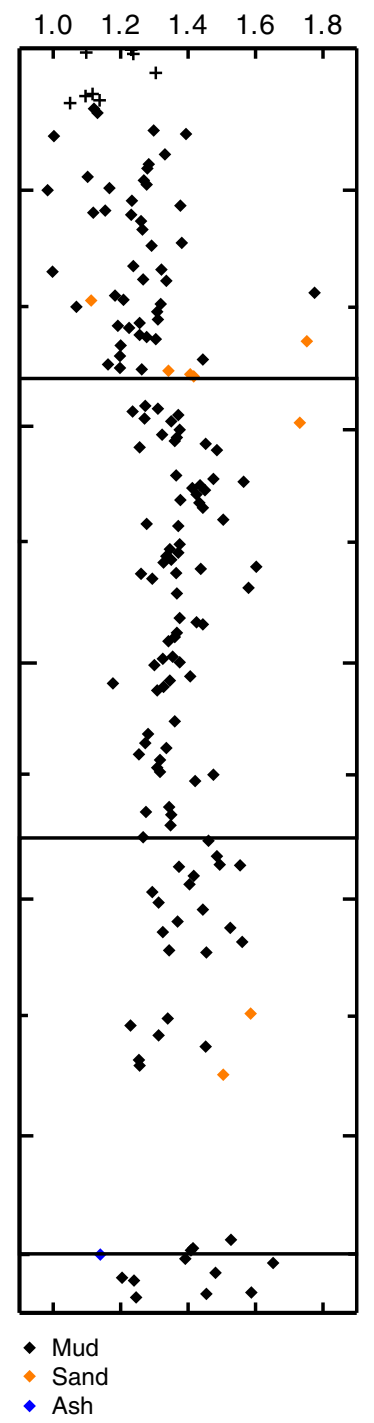


Figure F19. Profiles of $P$-wave velocity and velocity anisotropy, Hole C0011B.
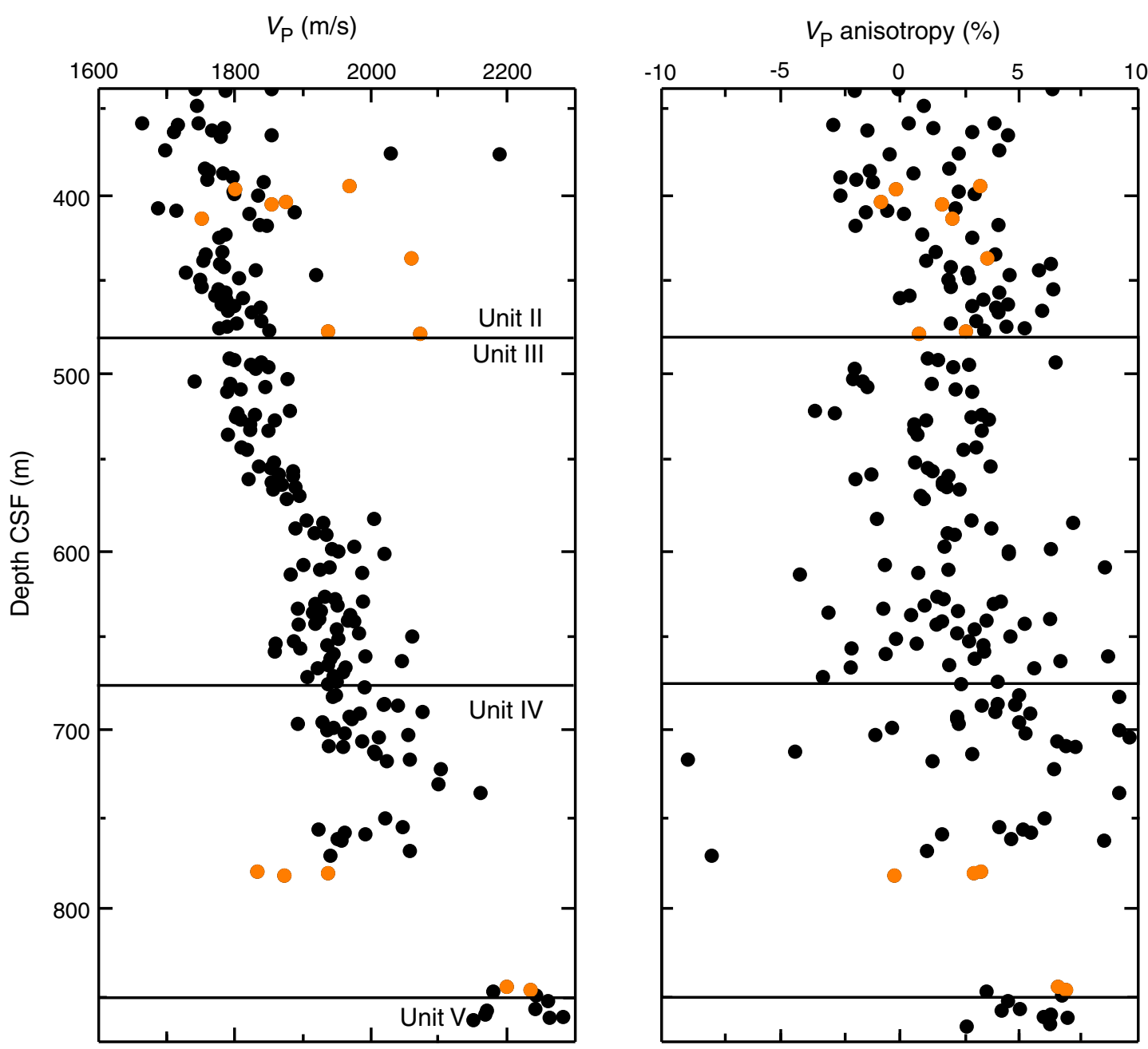

- Mud

- Sand 
Figure F20. Profiles of interstitial water geochemistry (corrected for sulfate), Hole C0011B. Correction assumes sulfate values $>0$ are result of drilling fluid contamination.

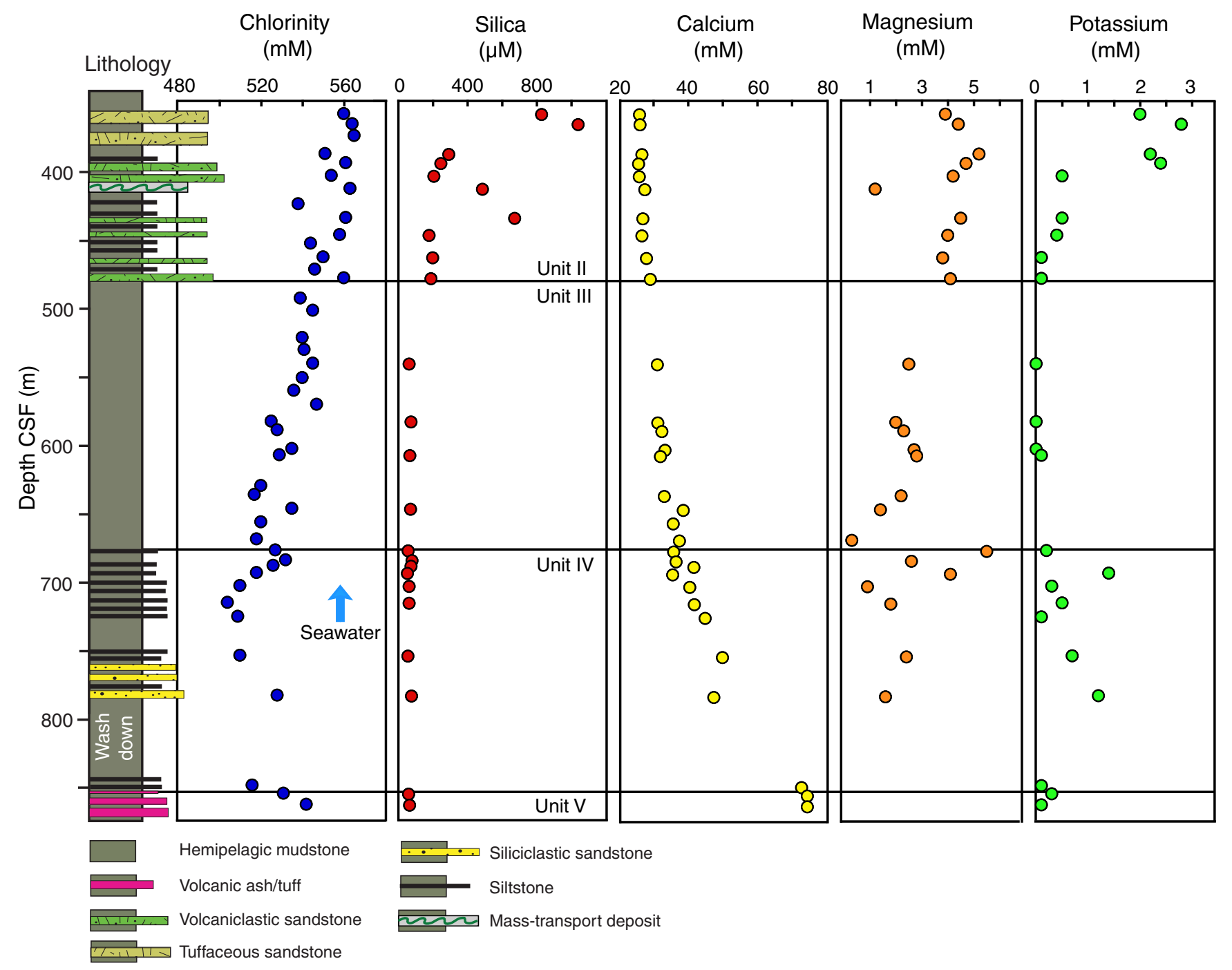


Figure F21. Organic geochemistry, Hole C0011B.

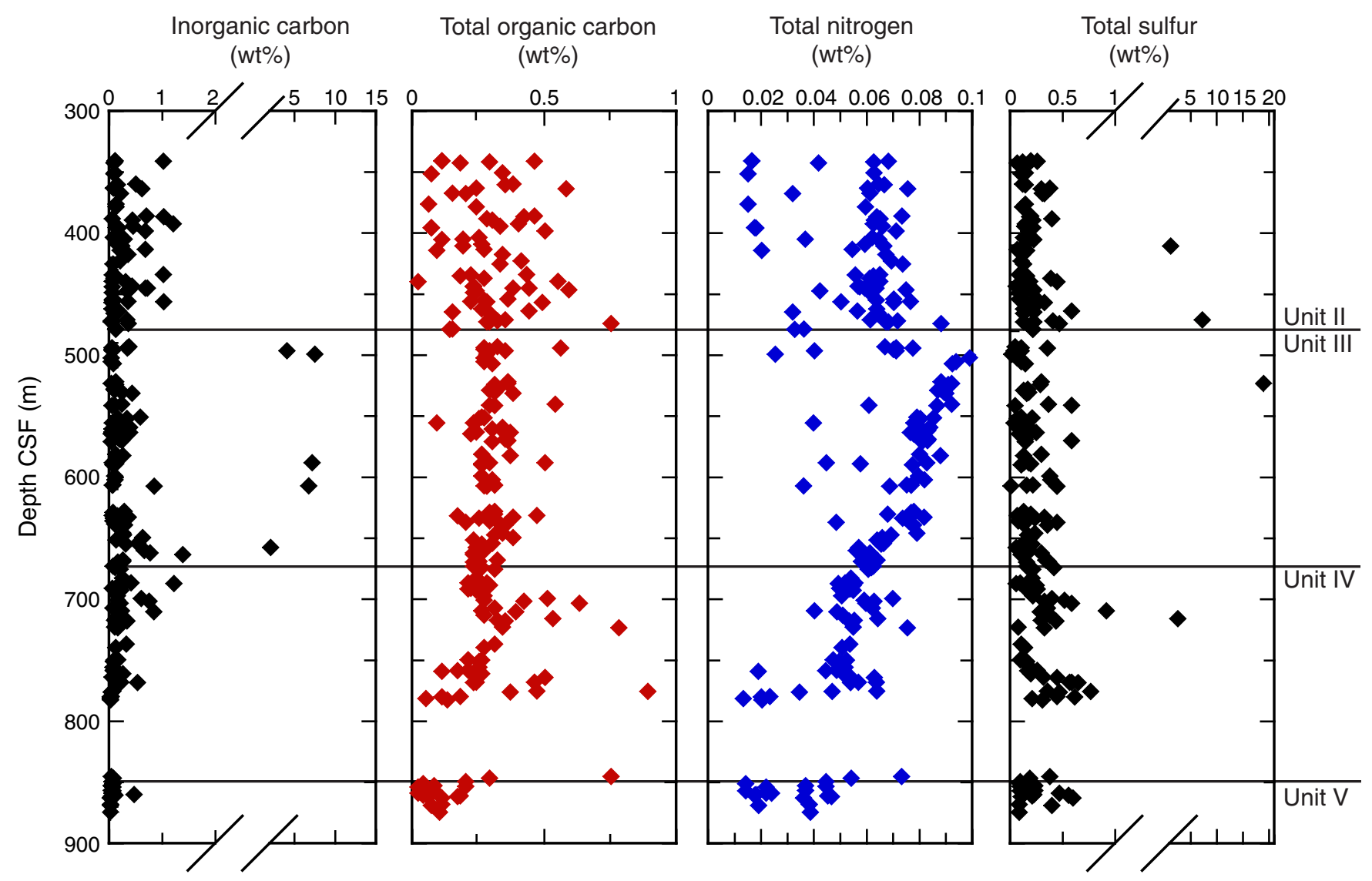


Figure F22. Hydrocarbon profiles showing concentrations of dissolved gasses in interstitial water, Hole C0011B.

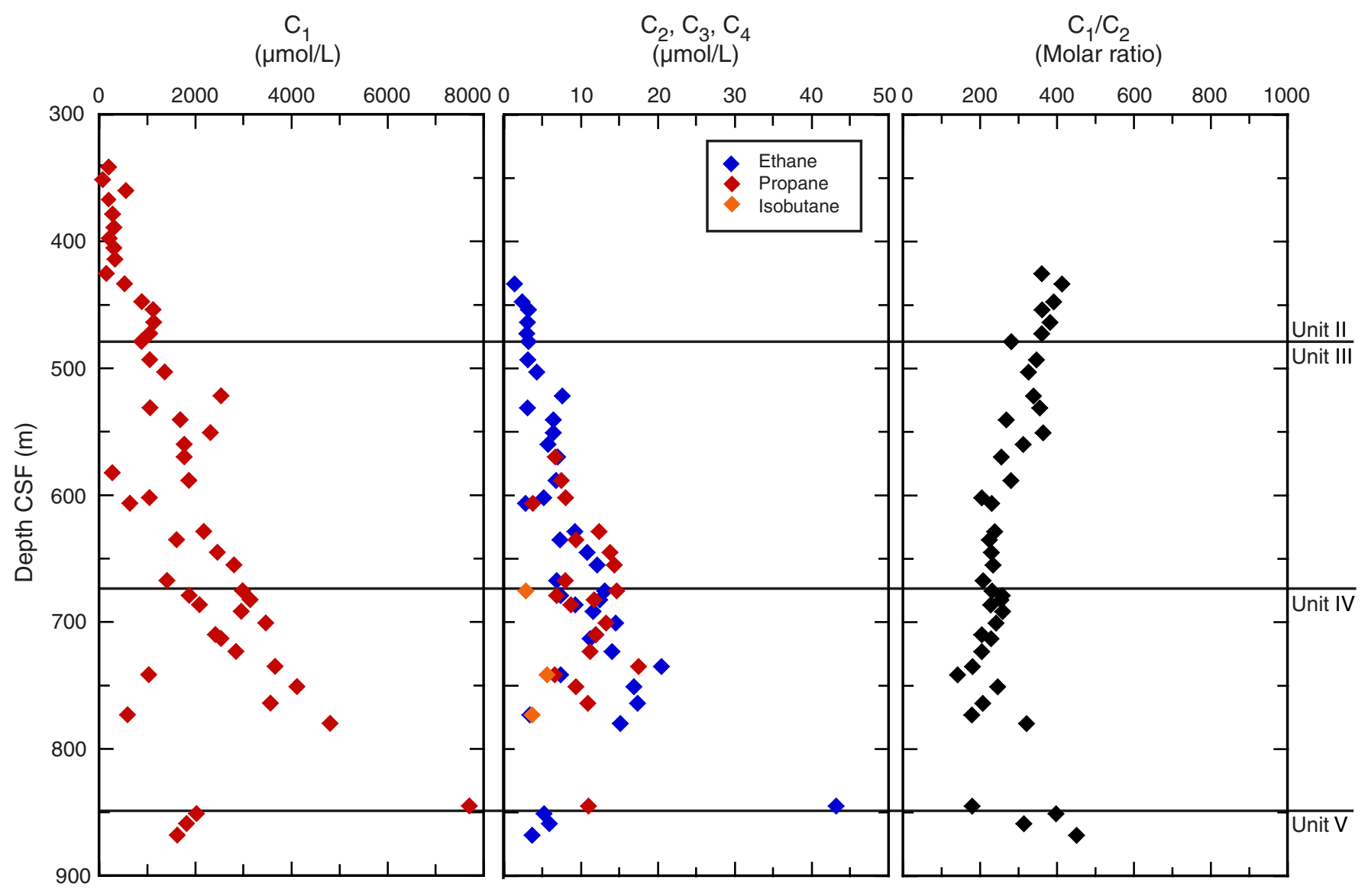


Figure F23. Lithologic units and depositional ages from nannofossil datums, Hole C0012A. TD = total depth.

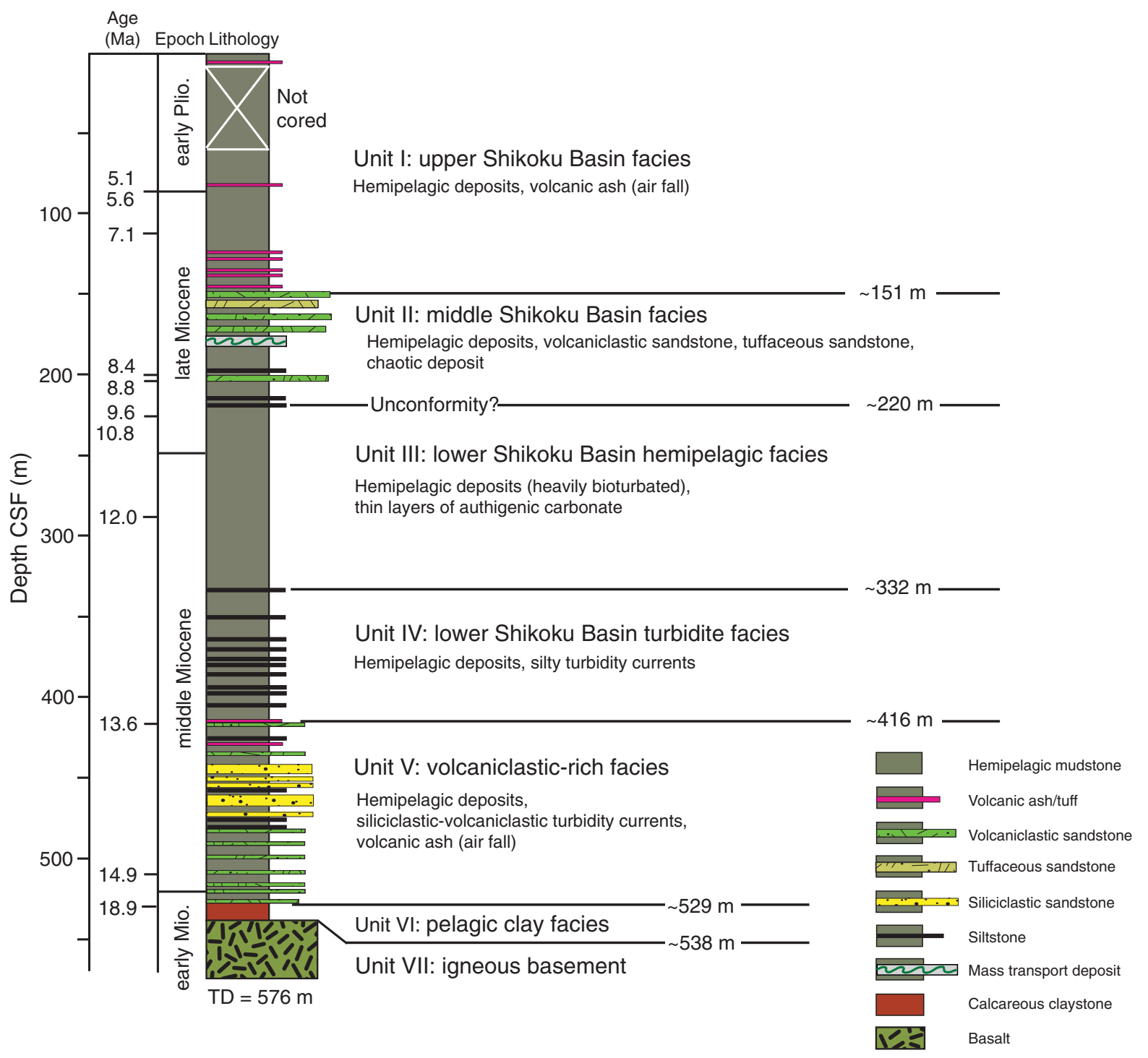


Figure F24. Lithologic column and core recovery, Hole C0012A.

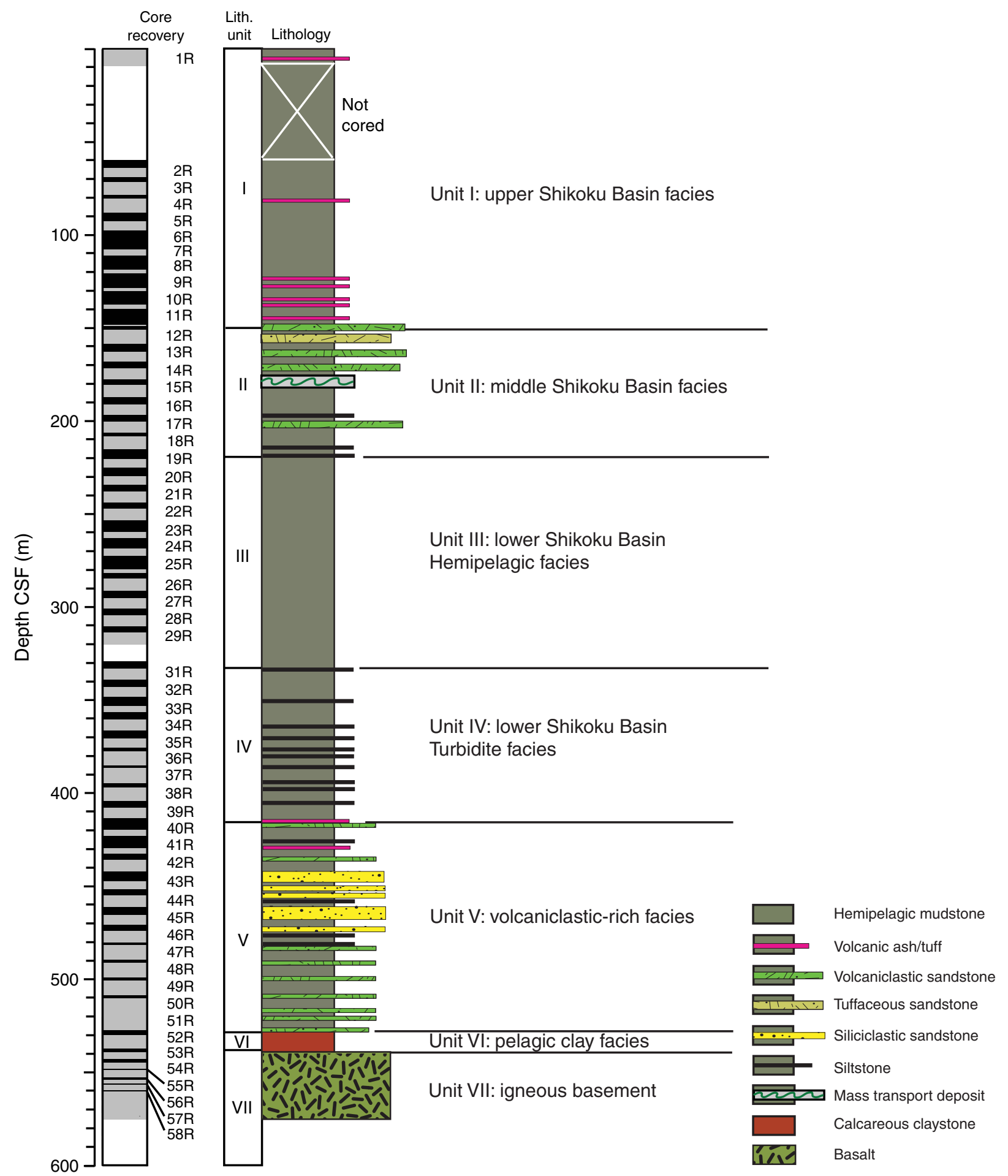


Figure F25. Bulk powder XRD profiles, Hole C0012A, reported in relative weight percent.

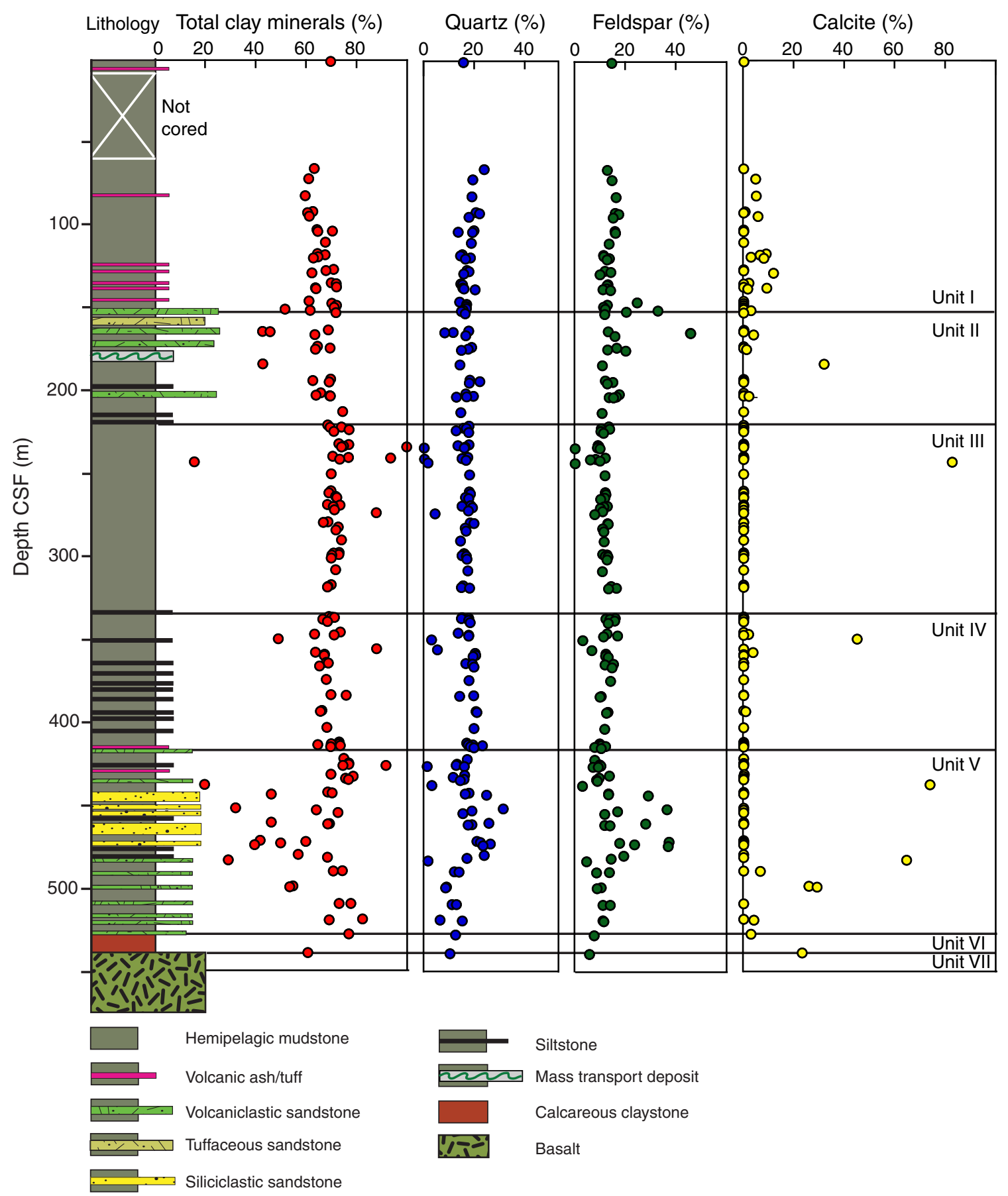


Figure F26. Bulk XRF profiles, Hole C0012A.

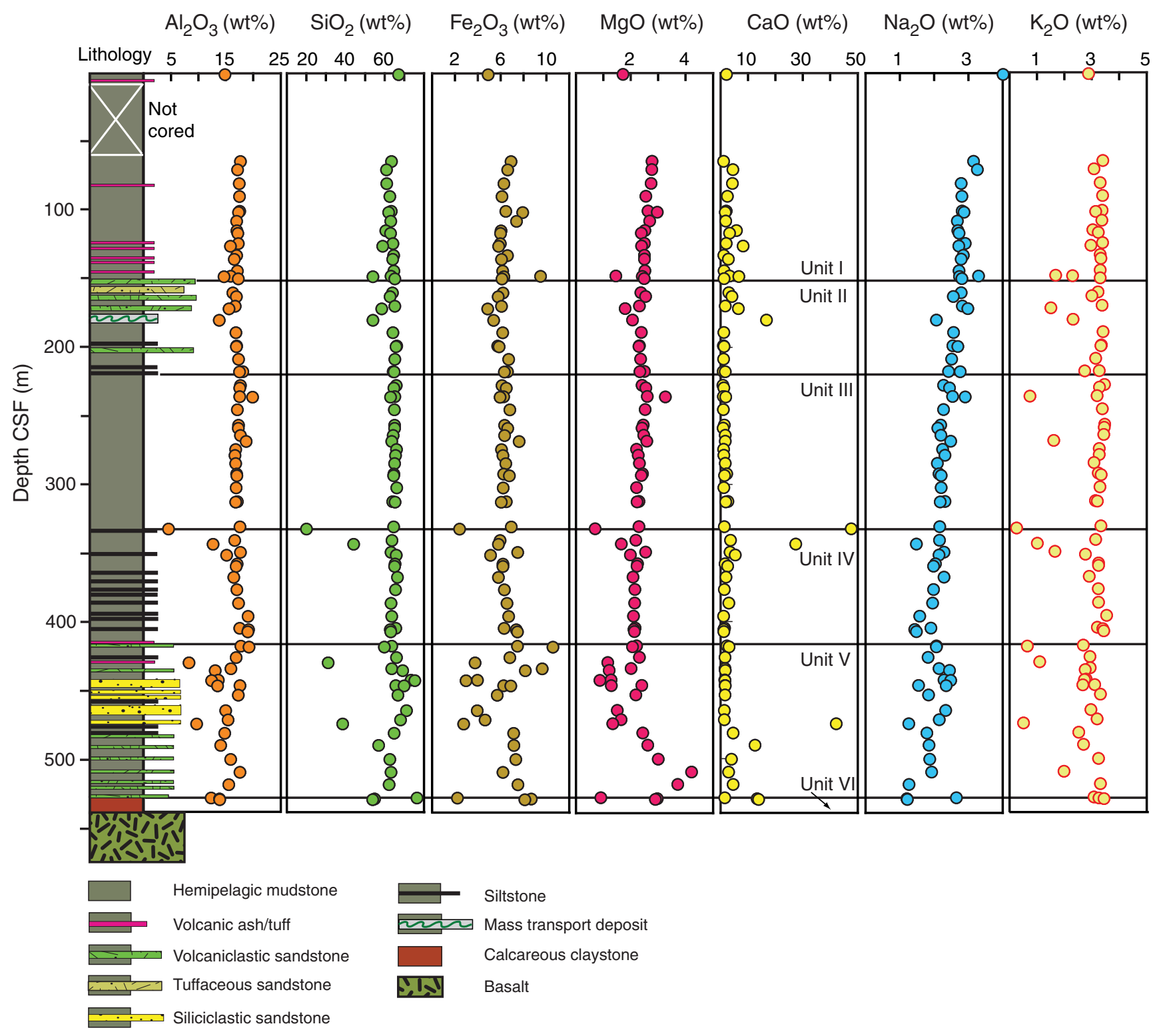


Figure F27. Photographs of (A) sandstone from lithologic Unit V and (B) sediment/basalt interface at lithologic Unit VI/VII boundary, Hole C0012A.

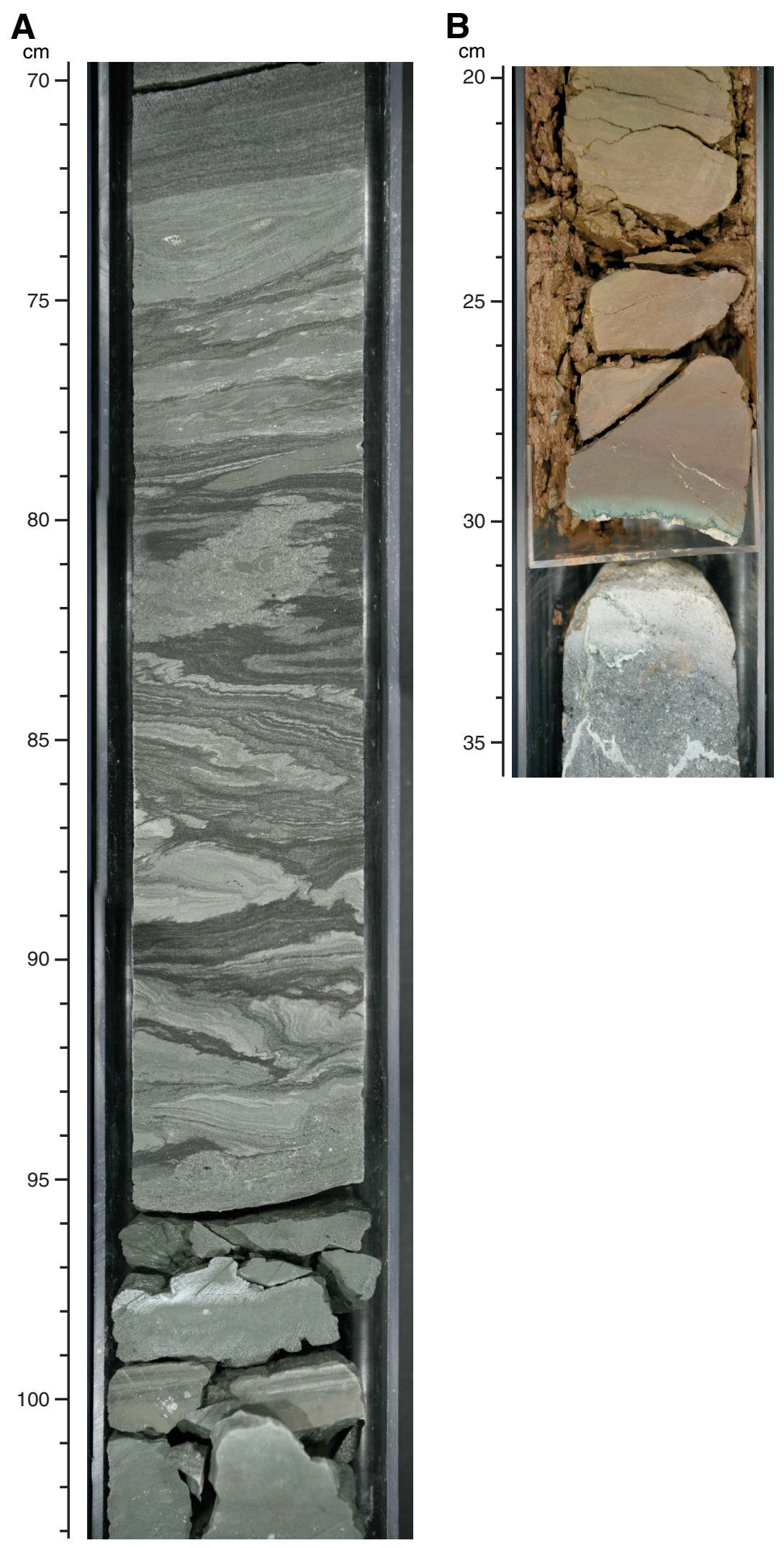


Figure F28. Orientation of planar structures, Hole C0012A. Position of possible unconformity (yellow) based on nannofossil datums.

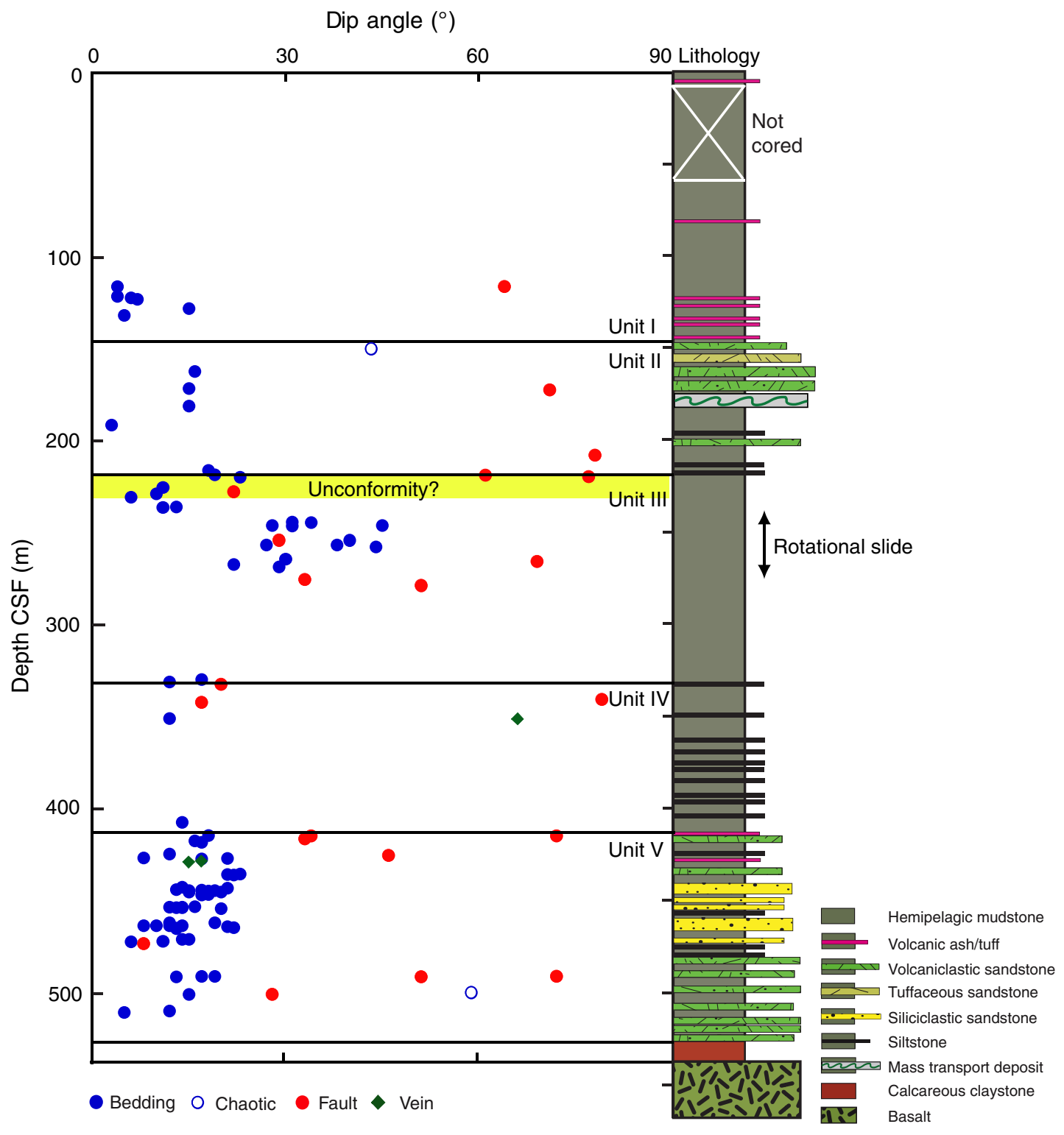


Figure F29. Integrated age-depth model, Hole C0012A. Unit boundary ages include errors of control points and line fitting.

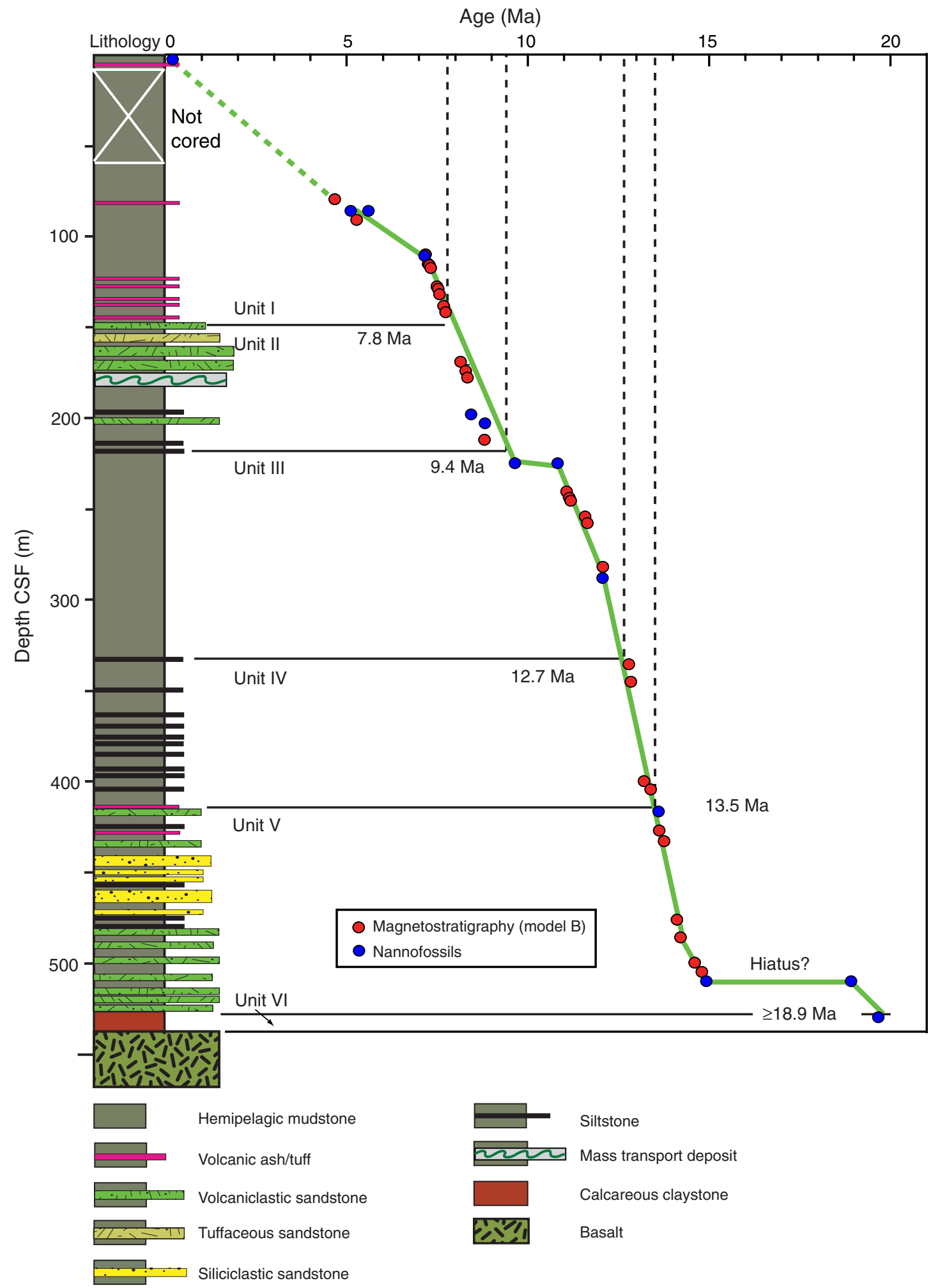


Figure F30. Discrete density, porosity, $P$-wave velocity, and thermal conductivity measurements for Hole C0012A. For thermal conductivity, $+=$ probe measurements, diamonds $=$ half-space measurements.
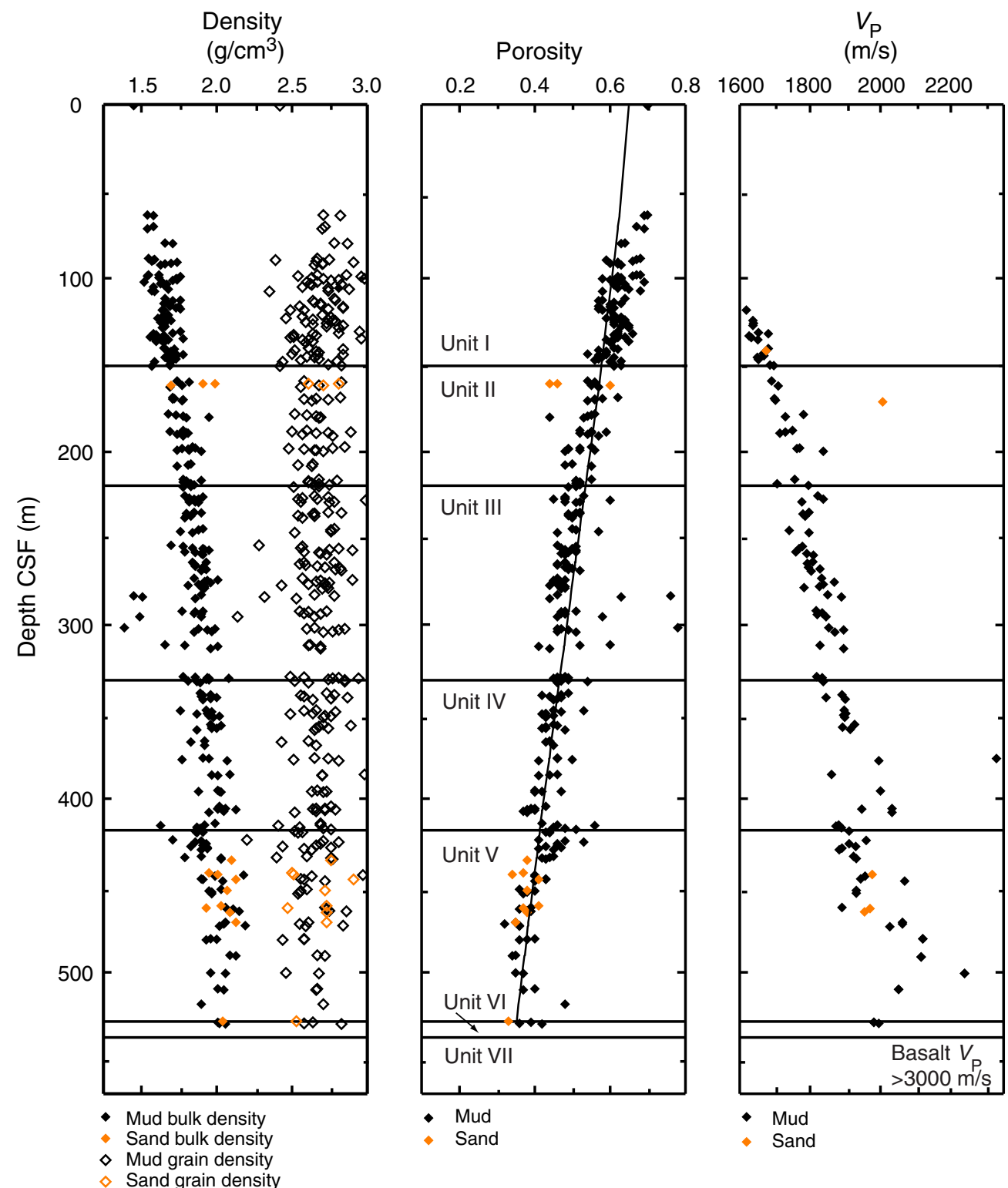
Thermal conductivity $(\mathrm{W} /[\mathrm{m} \cdot \mathrm{K}])$

$\begin{array}{lllll}1.00 & 1.25 & 1.50 & 1.75 & 2.00\end{array}$

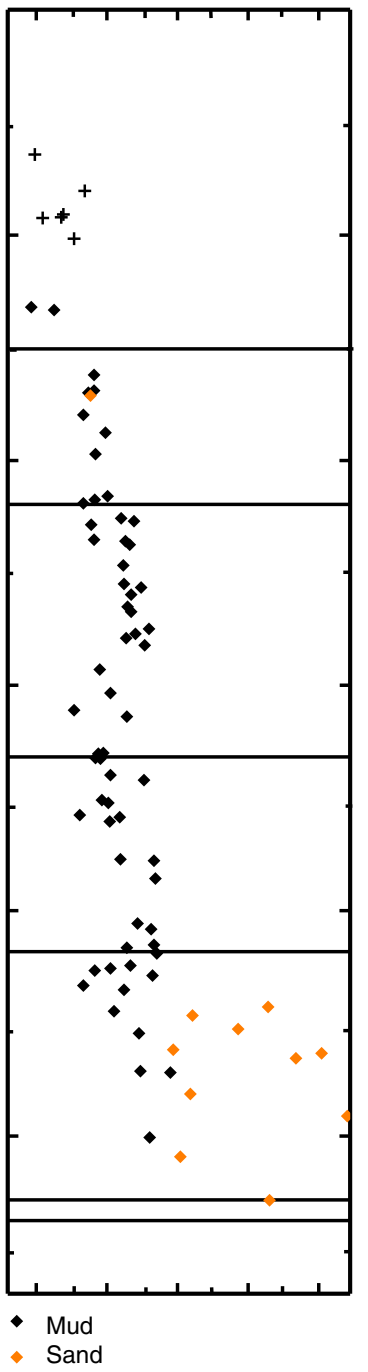


Figure F31. Interstitial water geochemistry profiles, Hole C0012A.

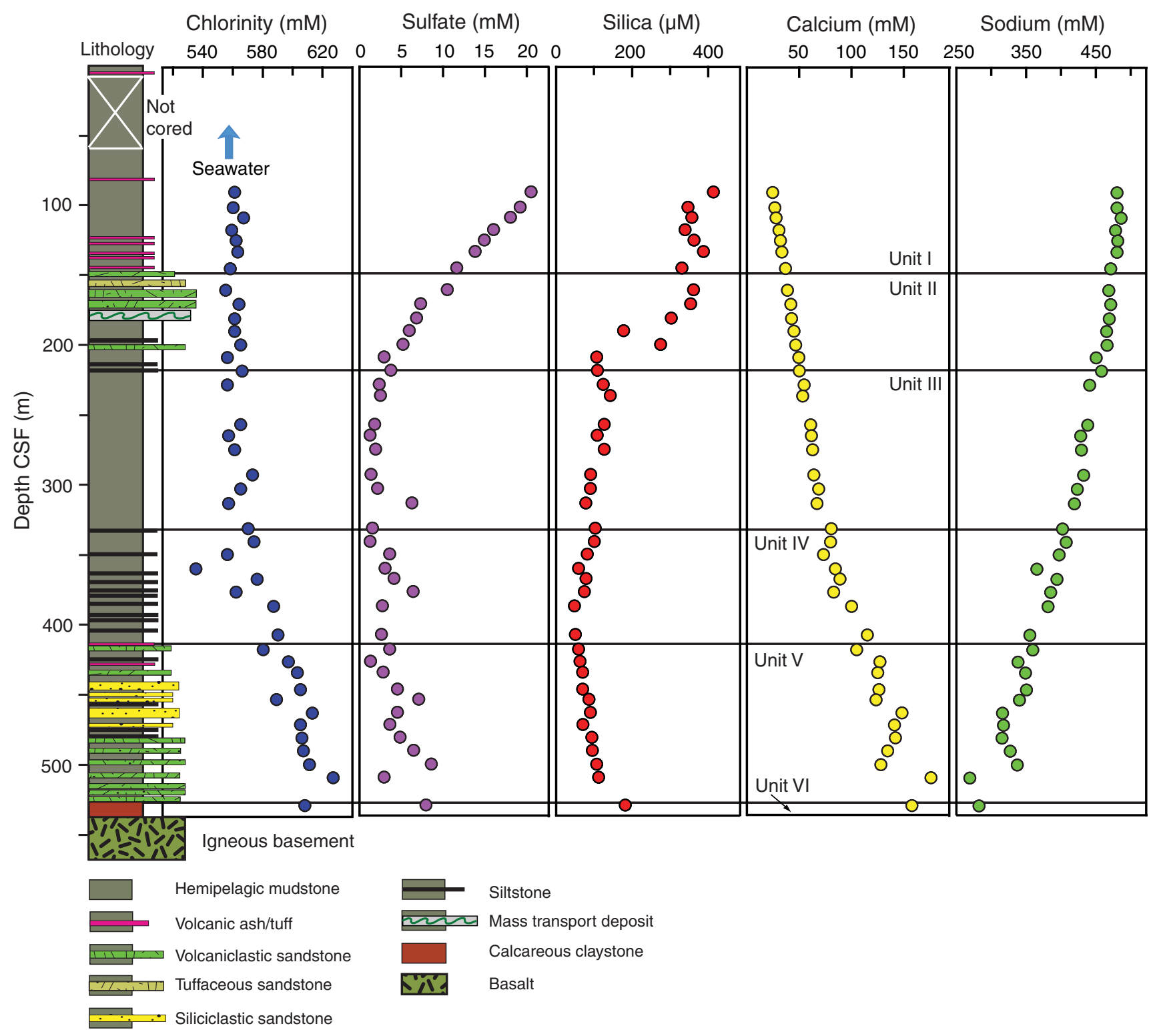


Figure F32. Profiles of dissolved hydrocarbon concentration in interstitial water, Hole C0012A.

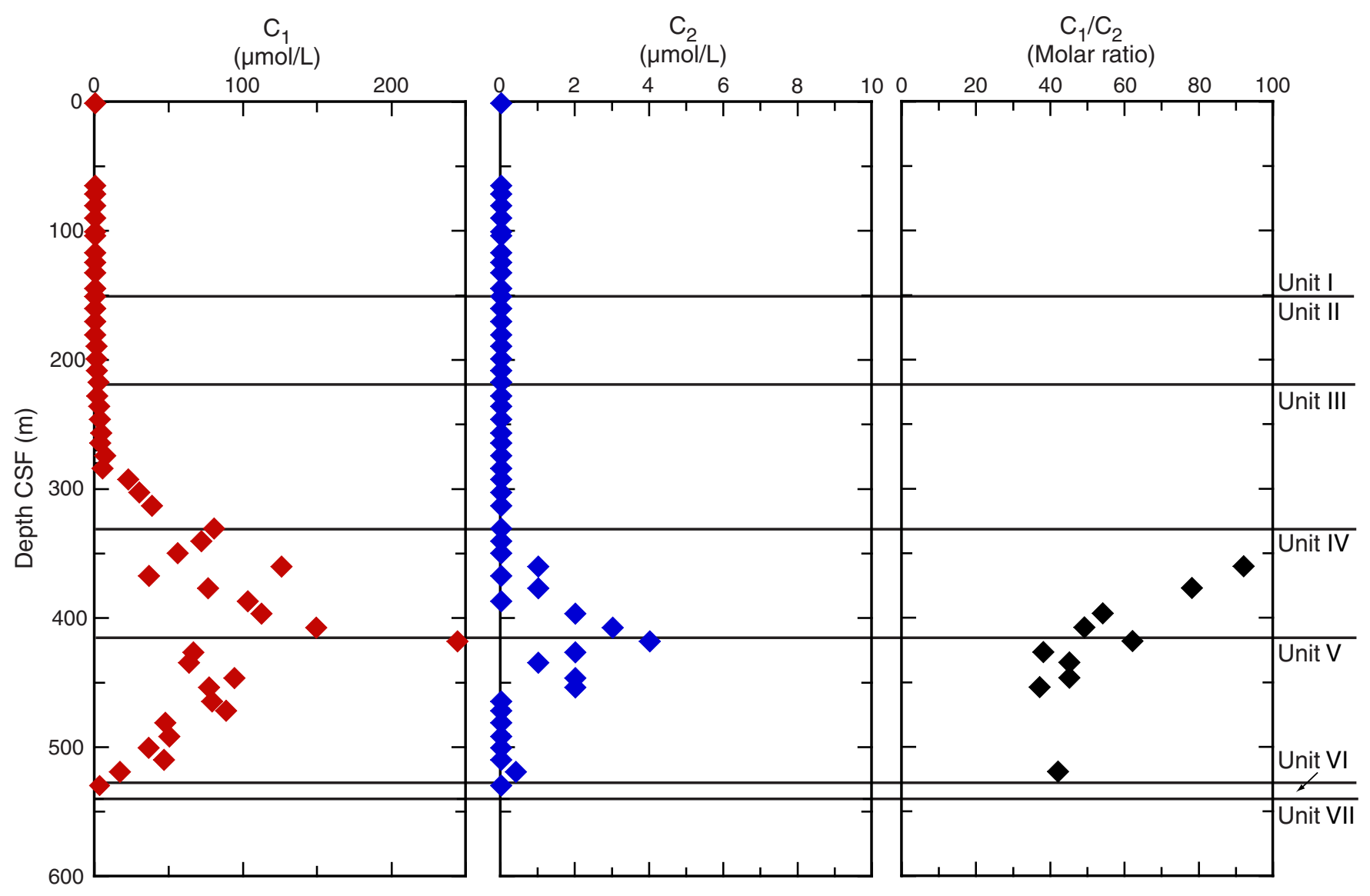


Figure F33. Organic geochemistry profiles, Hole C0012A.

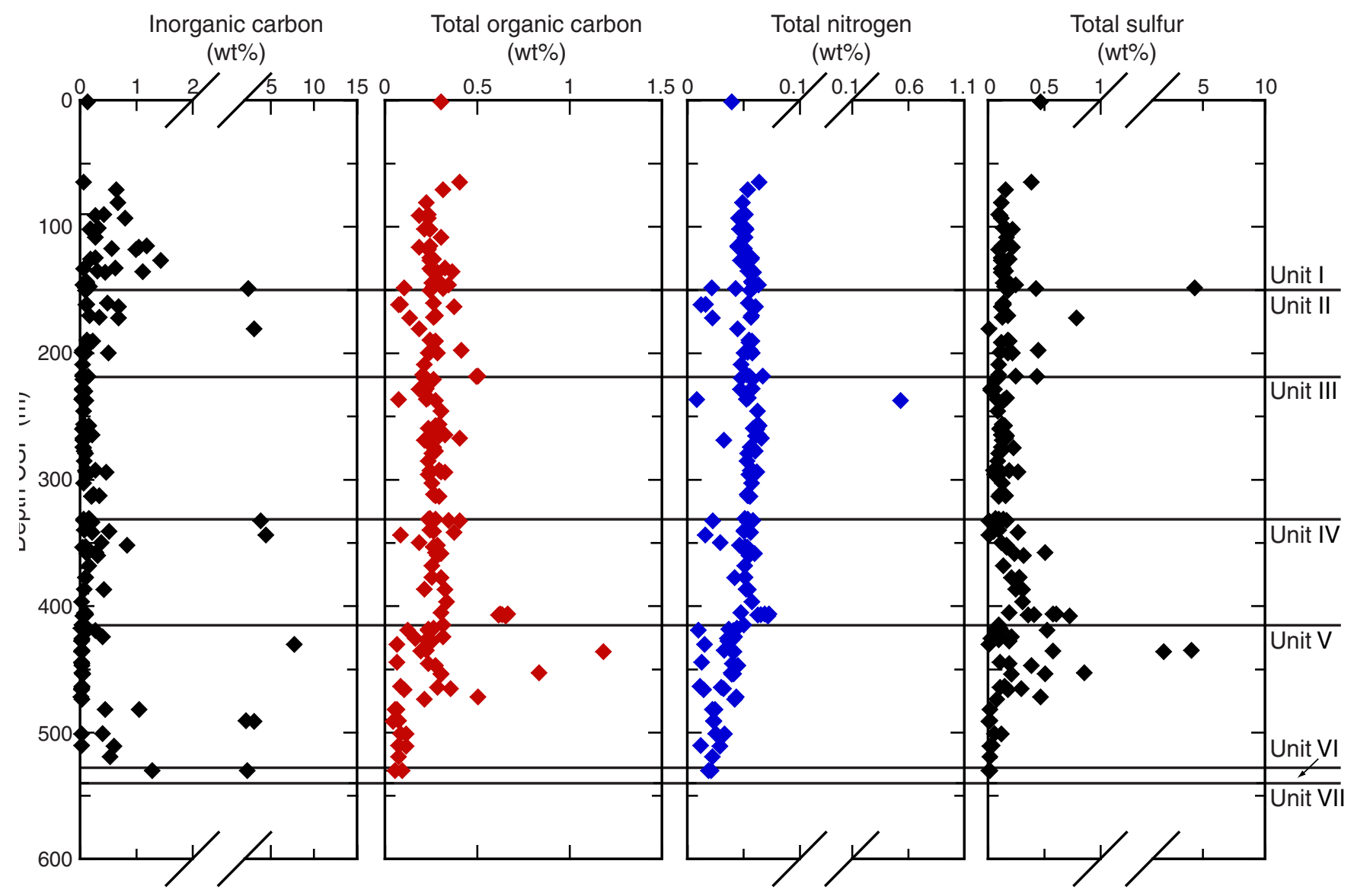


A

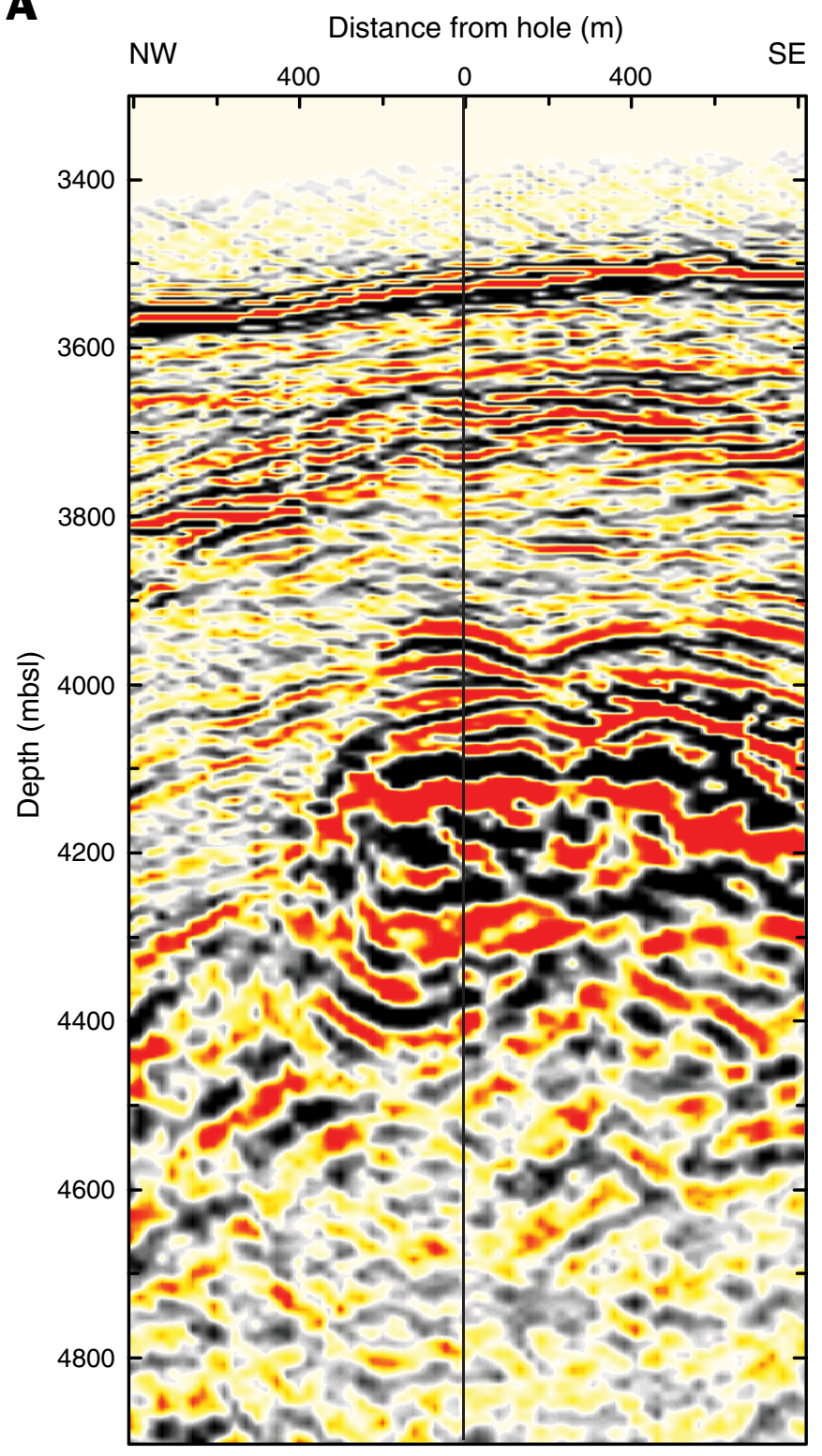

B

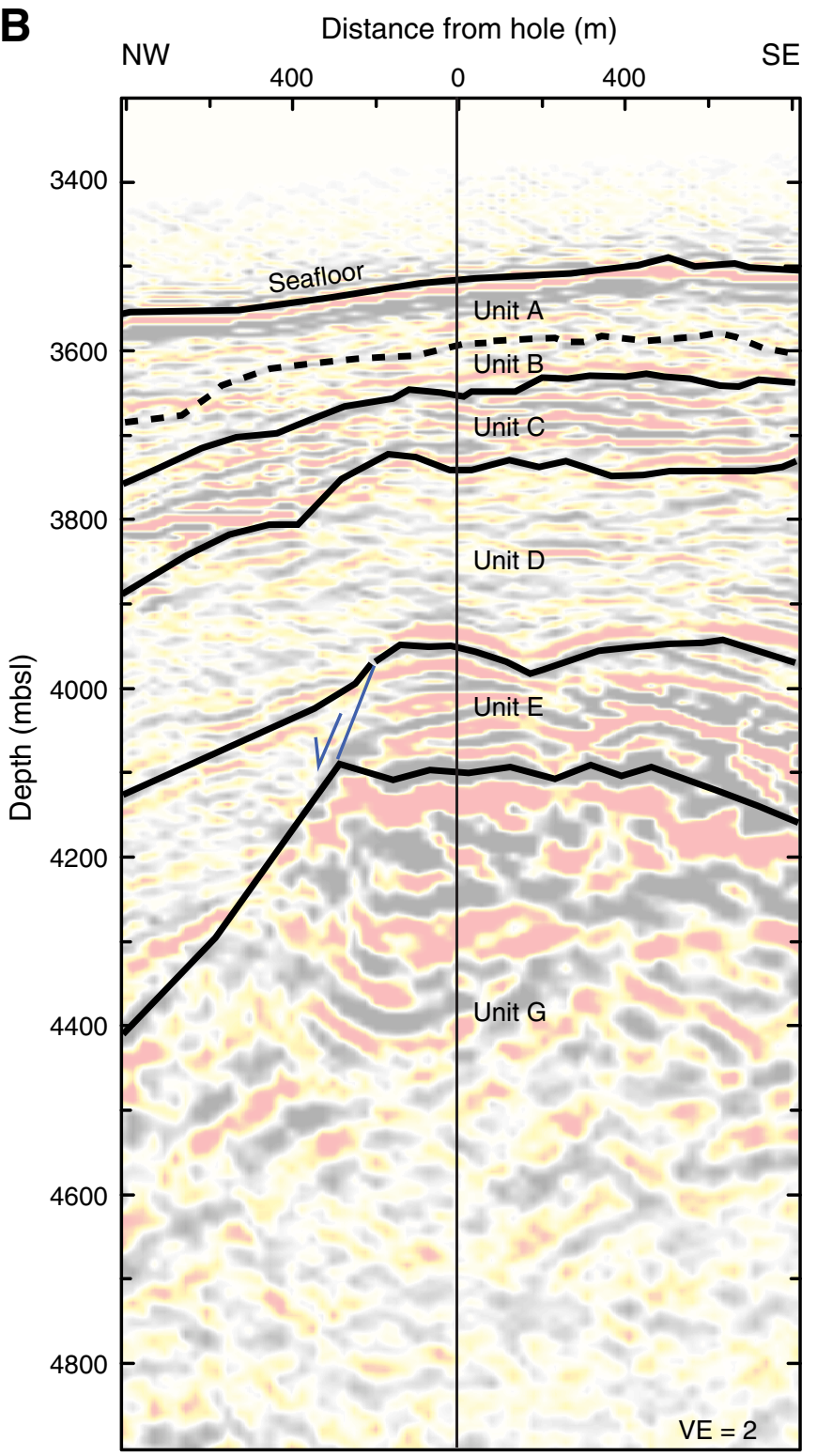


Figure F35. Stratigraphic correlation between Sites C0011 and C0012. For Site C0011, only logging-whiledrilling data from 0 to 340 m LSF. Unit boundary ages taken from integrated age-depth models.

Hole C0011B

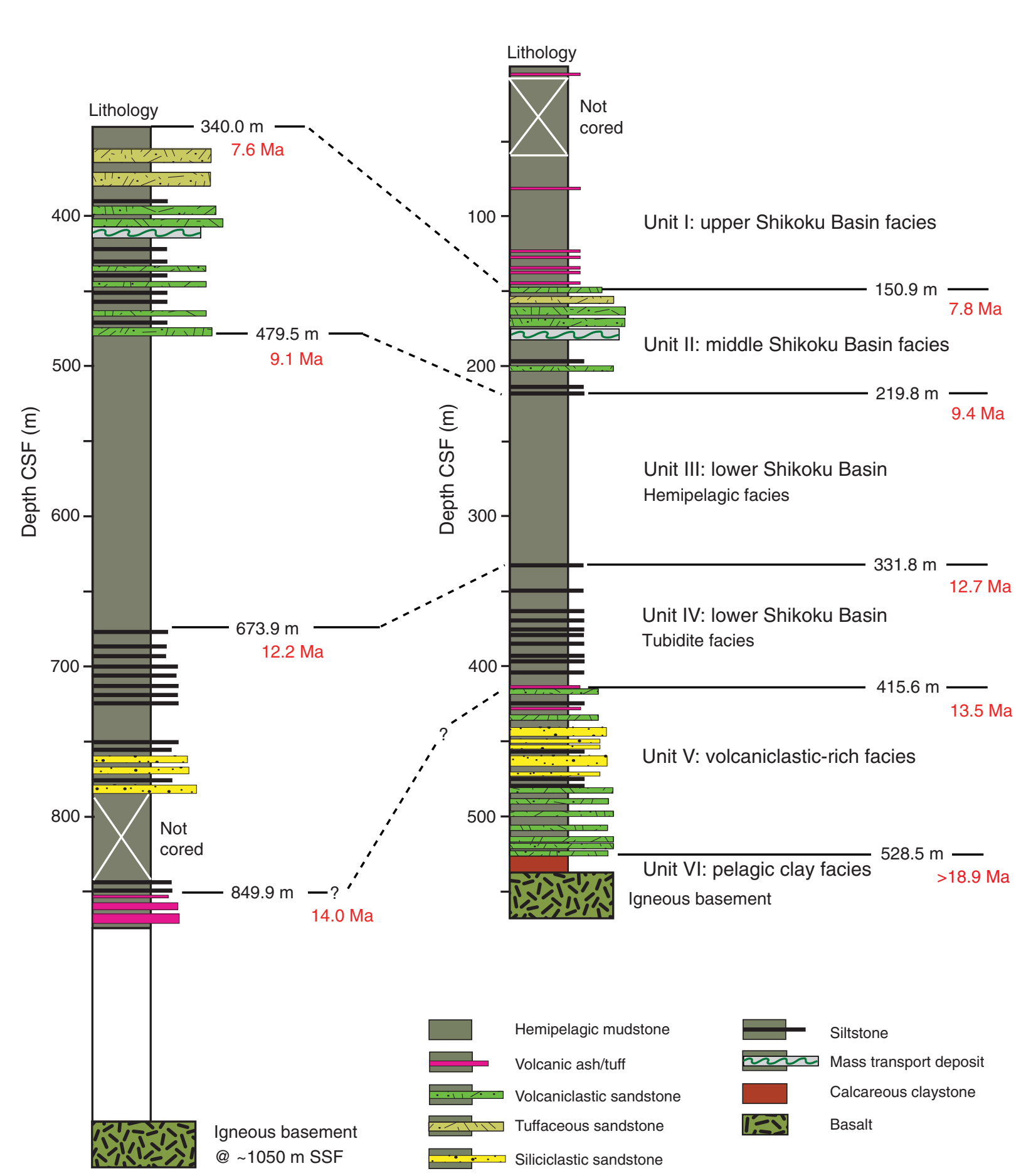

Hole C0012A 


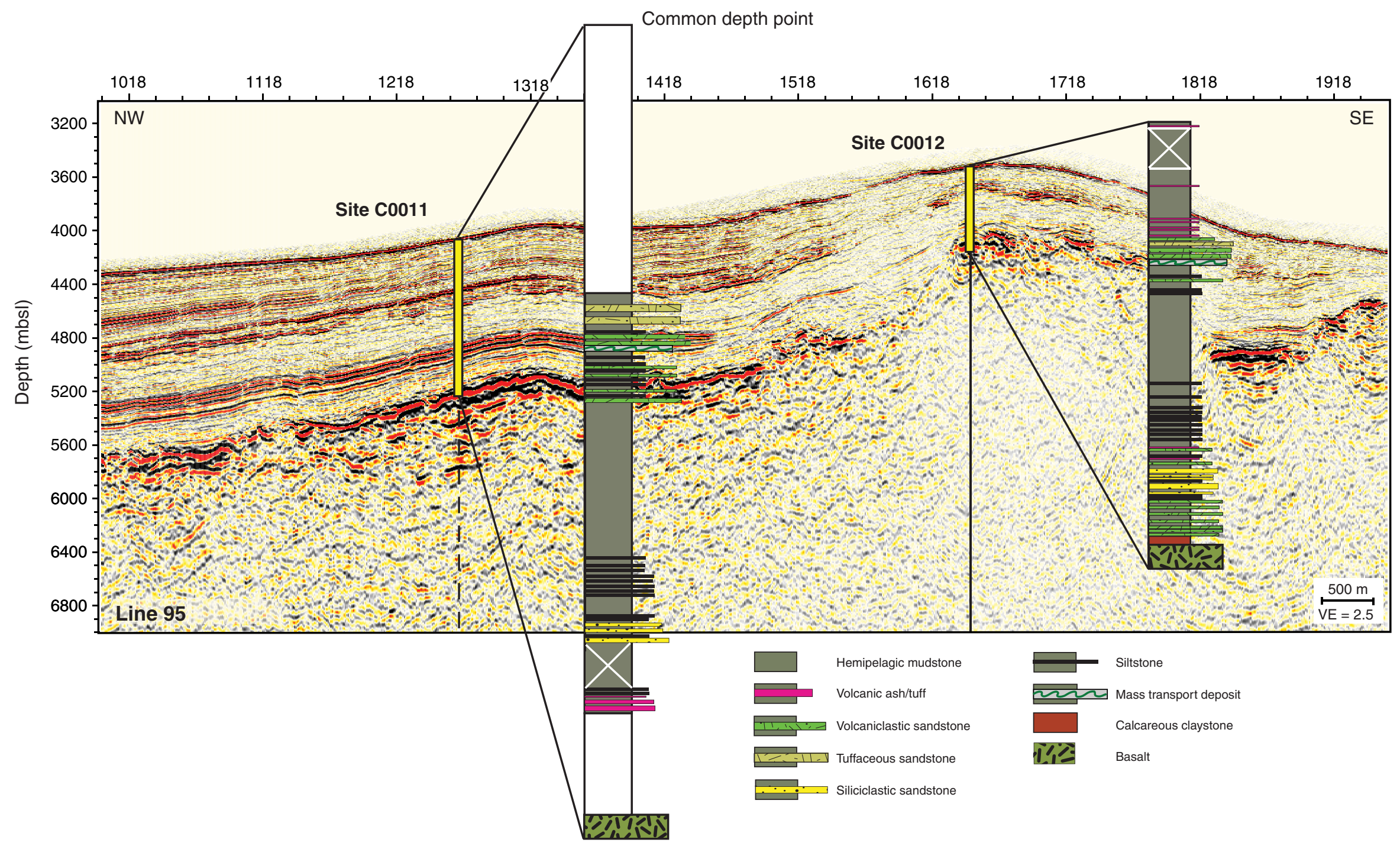


Figure F37. Chlorinity profiles on seismic background, Sites C0011 and C0012. VE = vertical exaggeration.

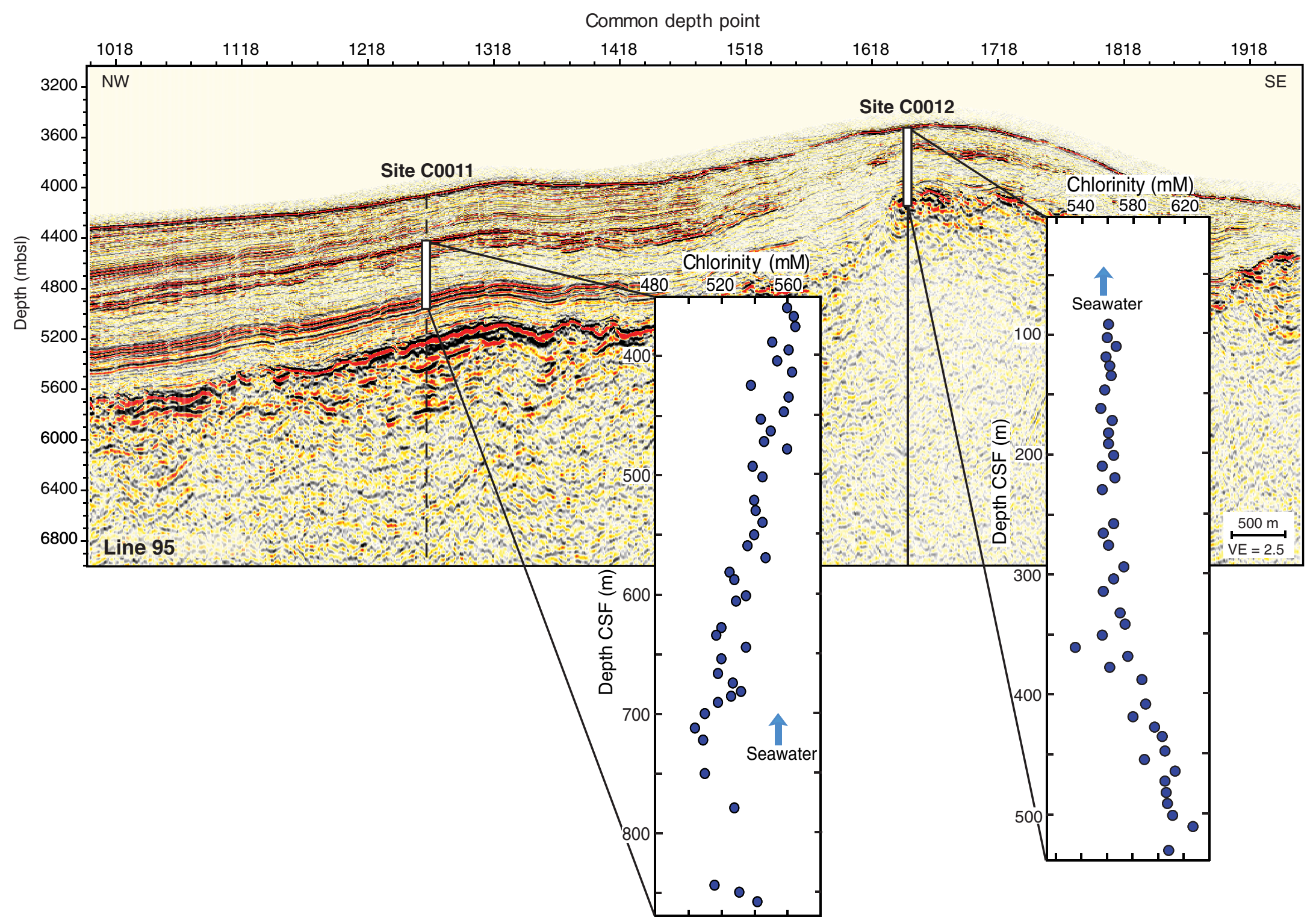


Table T1. Expedition 322 coring summary. (See table notes.)

\begin{tabular}{|c|c|c|c|c|c|c|c|c|c|c|}
\hline Hole & Latitude & Longitude & $\begin{array}{l}\text { Water } \\
\text { depth } \\
(\mathrm{mbsl})\end{array}$ & $\begin{array}{l}\text { Cores } \\
(N)\end{array}$ & $\begin{array}{c}\text { Cored } \\
(\mathrm{m})\end{array}$ & $\begin{array}{l}\text { Recovered } \\
\text { (m) }\end{array}$ & $\begin{array}{l}\text { Recovery } \\
\text { (\%) }\end{array}$ & $\begin{array}{c}\text { Drilled } \\
(\mathrm{m})\end{array}$ & $\begin{array}{l}\text { Penetration } \\
\text { (m) }\end{array}$ & $\begin{array}{l}\text { Time } \\
\text { on site } \\
\text { (days) }\end{array}$ \\
\hline \multirow[t]{2}{*}{ C0011B } & $32^{\circ} 49.7369^{\prime} \mathrm{N}$ & $136^{\circ} 52.9074^{\prime} \mathrm{E}$ & 4048.7 & 61 & 483.3 & 329.2 & 68.1 & 397.7 & 881.0 & 18 \\
\hline & \multicolumn{3}{|c|}{ Site $\mathrm{C} 0011$ totals: } & 61 & 483.3 & 329.2 & 68.1 & 397.7 & 881.0 & 18 \\
\hline C0012A & $32^{\circ} 44.888^{\prime} \mathrm{N}$ & $136^{\circ} 55.024^{\prime} \mathrm{E}$ & 3510.7 & 58 & 576.0 & 206.95 & 35.9 & 576.0 & 576.0 & 9 \\
\hline \multirow[t]{3}{*}{$\mathrm{C} 0012 \mathrm{~B}$} & $32^{\circ} 44.888^{\prime} \mathrm{N}$ & $136^{\circ} 55.024^{\prime} \mathrm{E}$ & 3510.7 & 0 & 0 & 0 & NA & 499.0 & 499.0 & 4 \\
\hline & \multicolumn{3}{|c|}{ Site C0012 totals: } & 58 & 576.0 & 206.95 & 35.9 & 1075.0 & 1075.0 & 12 \\
\hline & \multicolumn{3}{|c|}{ Expedition 322 totals: } & 119 & 1059.3 & 536.15 & 50.6 & 1472.7 & 1956.0 & 30 \\
\hline
\end{tabular}

Notes: $N=$ number. $N A=$ not applicable. 